\title{
Controls of the lithospheric thermal field of an ocean-continent subduction zone: the southern Central Andes
}

Constanza Rodriguez Piceda ${ }^{1,2}$, Magdalena Scheck-Wenderoth. ${ }^{1,3}$, Judith Bott ${ }^{1}$, Maria Laura Gomez Dacal $^{1}$, Mauro Cacace ${ }^{1}$, Michaël Pons ${ }^{1,2}$, Claudia. Prezzi ${ }^{4}$, and Manfred Strecker ${ }^{1}$

\footnotetext{
${ }^{1}$ HelmholtzZentrum GFZ - German Research Centre for Geosciences, Potsdam, Germany

${ }^{2}$ University of Potsdam, Institute of Geosciences, Potsdam, Germany

${ }^{3}$ RWTH Aachen University, Aachen, Germany

${ }^{4}$ IGEBA-(UBA-CONICET) Facultad de Ciencias Exactas y Naturales, Universidad de Buenos Aires, Buenos Aires, Argentina.
}

Corresponding author: Constanza Rodriguez Piceda (piceda@gfz-potsdam.de)

This manuscript has been submitted for publication in Lithosphere. Please note that the manuscript has not yet undergone peer-review. Subsequent versions of this manuscript may include revisions based on feedback and the peer-review process. If accepted in a peerreviewed journal, the post-review version of this manuscript will be available via the 'Peerreviewed Publication DOI' link on the EarthArXiv page for this paper. Please feel free to contact any of the authors; we welcome feedback.

\begin{abstract}
In an ocean-continent subduction zone, the assessment of the lithospheric thermal state is essential to determine the controls of the deformation within the upper plate and the dip angle of the subducting lithosphere. In this study, we evaluate the degree of influence of both the configuration of the upper plate and variations of the subduction angle on the lithospheric thermal field of the southern Central Andes $\left(29^{\circ}-39^{\circ} \mathrm{S}\right)$. Here, the subduction angle increases from subhorizontal $\left(5^{\circ}\right)$ north of $33^{\circ} \mathrm{S}$, to steep $\left(\sim 30^{\circ}\right)$ in the south. We derived the $3 \mathrm{D}$ temperature and heat flow distribution of the lithosphere in the southern Central Andes considering conversion of $S$ wave tomography to temperatures together with steady-state conductive modeling. We found that the orogen is overall warmer than the forearc and the foreland, and that the lithosphere of the northern part of the foreland appears colder than its southern counterpart. Sedimentary blanketing and the thickness of the radiogenic crust exert the main control on the shallow thermal field ( $<50 \mathrm{~km}$ depth). Specific conditions are present where the oceanic slab is relatively shallow ( $<85 \mathrm{~km}$ depth) and the radiogenic crust is thin, This configuration results in relatively colder temperatures compared to regions where the radiogenic crust is thick and the slab is steep. At depths $>50 \mathrm{~km}$, the temperatures of the overriding plate are mainly controlled by the mantle heat input and the subduction angle. The
\end{abstract}


thermal field of the upper plate likely preserves the flat subduction angle and influences the spatial distribution of shortening.

\section{Introduction}

Temperature exerts a first-order control on the rheology of the lithosphere, affecting the depth of the brittle-ductile transition zone and the occurrence of thermally activated creep processes (Mareschal \& Jaupart, 2013; Turcotte \& Schubert, 2002). In an active oceancontinent convergent plate-boundary system, the assessment of the temperature distribution within the lithosphere is crucial for understanding the mechanisms controlling subduction geometry (e.g., slab dip and subduction-zone curvature) and the localization of deformation within the upper plate, including the vergence of thrust belts (R.W. Allmendinger \& Gubbels, 1996; Barrionuevo et al., 2021; F. Ibarra et al., 2021; J. Kley et al., 1999; Kusznir \& Park, 1984; Liu, 2020). Estimating the thermal state of the system is challenging, however, as it requires deciphering the complex and continuous interplay between different heat-transport mechanisms (conduction and convection) and heat sources. These across-scales phenomena include heat conduction, advection of the oceanic plate that steadily supplies colder material, variations of thermal properties within the plates (radiogenic heat production and thermal conductivity), frictional heating along the subduction interface, latent heat due to mineralogical phase transformations within the oceanic plate, and adiabatic heating in the asthenosphere (for a review, see Goes et al., 2020; Peacock, 2020).

Many modeling studies (Boonma et al., 2019; Č́ížková \& Bina, 2013; van Keken et al., 2019) have considered the temperature distribution of the lithosphere as the main driver of the dynamics of a subduction system. These studies adopted a simplified configuration of the upper plate in terms of its thickness and rock composition (van Keken et al., 2019). However, the continental lithosphere is the product of a complex tectonic and magmatic history, involving terrane amalgamation, trench erosion, crustal thickening during subduction and collision, and extensional overprinting either during the final stages of orogeny or from deep-seated processes in the mantle (Rudnick \& Gao, 2003; Taylor, 1967). To address these considerations, other modeling studies have effectively shown how the present-day thermal field varies with respect to thickness and compositional heterogeneities within the lithosphere (Freymark et al., 2017; Kaban et al., 2014; Scheck-Wenderoth et al., 2014; Sippel et al., 2017; Spooner et al., 2020; Tesauro et al., 2009) and how these variations ultimately affect the long-term rheology of the lithospheric plate (Anikiev et al., 2020; Ibarra et al., 2021; Ibarra \& Prezzi, 2019; Tesauro et al., 2009). 
The southern Central Andes (SCA, $27^{\circ}-40^{\circ} \mathrm{S}$, Fig. 1) are a suitable region for studying the effect of both a heterogeneous configuration of the upper plate and differences in subduction geometry on the lithospheric thermal field in an ocean-continent convergent plate-boundary system for several reasons. Bordering the convergent margin between the oceanic Nazca Plate and the continental South American Plate, the SCA encompass several morphotectonic provinces across the strike of the subduction zone, each characterized by a distinct pre-Cenozoic geological history and lithospheric configuration. These differences are rooted in complex tectonic and magmatic episodes of shortening and extension that span from the Neoproterozoic to the Quaternary (Astini et al., 1995; Azcuy \& Caminos, 1987; Giambiagi et al., 2003; Jordan et al., 1983; Kay et al., 2006; LLambias et al., 1993; Llambias \& Sato, 1990; Mpodozis \& Kay, 1990; Ramos et al., 1996). Major pulses of Andean deformation are thought to have occurred during the Late Cretaceous and Miocene (Boyce et al., 2020; Fennell et al., 2015), when the style of deformation was significantly influenced not only by the characteristics of the subducting plate (Jonas Kley \& Monaldi, 2002; Oncken et al., 2006; G. Yáñez \& Cembrano, 2004), but also by the reactivation of inherited tectonic heterogeneities, which influenced Cenozoic phases of erosion, sedimentation, and geomorphic evolution (del Papa et al., 2013). The SCA are subdivided into four first-order morphotectonic provinces: the forearc, the magmatic arc, the back-arc, and the foreland (Fig. 1; Allmendinger et al., 1997; Isacks, 1988; Jordan et al., 1983). These extensive regions are in turn subdivided into morphotectonic provinces that are characterized by distinct structural and geomorphic features. For the purposes of this study, we have defined as the Andean orogen only the magmatic arc and backarc provinces that constitute the orogenic wedge, and thus not included the fold-and-thrust belt of the Precordillera and the Payenia volcanic province. The main features of the foreland are the reverse-fault bounded basement uplifts of the Sierras Pampeanas and the Neuquén and Cuyo basins (Fig. 1).

A distinct feature of the SCA is the variation in the subduction angle along the strike of the subduction zone, transitioning between $33^{\circ} \mathrm{S}$ and $34.5^{\circ} \mathrm{S}$ from subhorizontal $\left(<5^{\circ}\right)$ in the north (Chilean-Pampean flat-slab area; Ramos et al., 2002) to relatively steep $\left(\sim 30^{\circ}\right)$ in the south (Fig. 1; e.g., Barazangi \& Isacks, 1976; Cahill \& Isacks, 1992). Even though the presentday subduction regime has been active since at least Early Jurassic (Maloney et al., 2013 and references therein), the flattening of the slab north of $33^{\circ} \mathrm{S}$ presumably began at $\sim 19 \mathrm{Ma}$ (Jones et al., 2014, 2015, 2016), finally achieving its subhorizontal configuration at 7-6 Ma (for a review see Kay et al., 2006; Kay \& Mpodozis, 2002; Ramos et al., 2002). It has been proposed that this flattening event is responsible for the absence of present-day magmatism between $27^{\circ}-$ 
$33^{\circ} \mathrm{S}$ (Fig. 1) (Kay et al., 2006; Kay \& Mpodozis, 2002). Several causal mechanisms have been suggested for triggering flat subduction at these latitudes, including: (i) buoyancy of the slab due to the subduction of an aseismic ridge (Gutscher, 2002; Kay \& Mpodozis, 2002; Yáñez et al., 2001); (ii) fast trenchward motion of the overriding plate that inhibits slab rollback and drives the trench to retreat (van Hunen et al., 2000); and (iii) enhanced coupling between the oceanic and continental plates due to the greater strength of the continental plate (Hu et al., 2016; Vlad C. Manea et al., 2012; Rodriguez Piceda et al., 2021; Sharples et al., 2014).

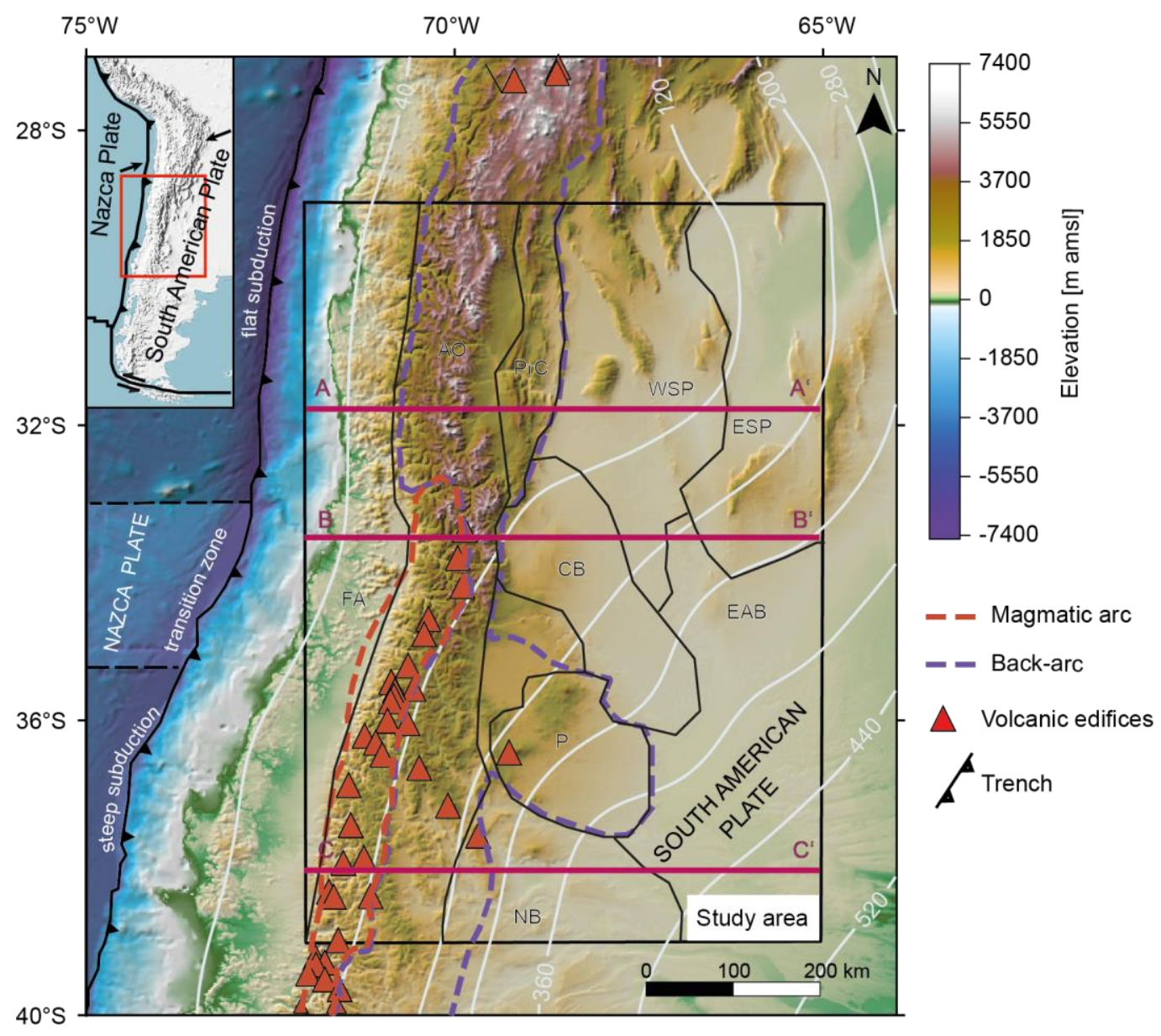

Figure 1. Topography and bathymetry of the region based on the ETOPO1 global relief model (Amante \& Eakins, 2009), showing the extent of the subduction segments with steepening subduction angles from north to south. The boundaries between the subduction segments are indicated with black dashed lines. The depth contours (km below sea level) of the top of the slab from SLAB2 (Hayes et al., 2018) are shown in white lines. The black rectangle denotes the extent of the area modeled in this study. The boundaries between the main morphotectonic provinces are shown in black lines. Red triangles show the location of active volcanic edifices. The purple dashed lines enclose the back-arc domain, and the red dashed lines the magmatic arc. The magenta lines show the location of the cross-sections in figure 13. Abbreviations of main tectonic provinces: $\mathrm{AO}=$ Andean orogen, $\mathrm{CB}=$ Cuyo Basin, $\mathrm{ESP}=$ Eastern 
Sierras Pampeanas, $\mathrm{EAB}=$ extra-Andean basins, $\mathrm{FA}=$ forearc, $\mathrm{NB}=$ Neuquén Basin, $\mathrm{P}=$ Payenia volcanic province, $\operatorname{Prc}=$ Precordillera, $\mathrm{WSP}=$ Western Sierras Pampeanas.

In the SCA, surface heat flow, shallow subsurface temperatures, and magmatic activity vary significantly across the subduction system, which generally has been attributed to the geometry of the subducting Nazca plate ( Hamza et al., 2005; Hamza \& Muñoz, 1996; van Hunen et al., 2000, 2002, 2004; Marot et al., 2014; Uyeda \& Watanabe, 1982; Wagner et al., 2006; L. S. Wagner et al., 2005; Ward et al., 2013). Early studies (Hamza et al., 2008; Hamza et al., 2005; Hamza \& Muñoz, 1996; Uyeda \& Watanabe, 1982), based on lower surface heatflow values $\left(20-70 \mathrm{mWm}^{-2} \mathrm{~V}_{\mathrm{s}} .50-120 \mathrm{mWm}^{-2}\right)$, suggested that the flat-slab segment is colder than its steeper counterparts, a hypothesis which was also supported by geodynamic numerical modeling (van Hunen et al., 2000, 2002, 2004) and seismic tomography (Marot et al., 2014; Wagner et al., 2006; Wagner et al., 2005; Ward et al., 2013). According to the latter studies, low $\mathrm{v}_{\mathrm{p}} / \mathrm{v}_{\mathrm{s}}$ ratios $(P$ wave/S wave velocity $<1.75)$ characterize the flat-slab segment in the northern part of the SCA, in contrast to the higher $\mathrm{v}_{\mathrm{p}} / \mathrm{v}_{\mathrm{s}}$ ratios encountered to the south, which are within the range typically found for most subduction zones (Manea et al., 2017). The thermal contrast between the two differently dipping segments in the SCA is commonly linked to variations in the extent of the mantle wedge and arc magmatism, both of which are drastically reduced in the flat-slab segment (Gutscher et al., 2000; Henry \& Pollack, 1988; Kay et al., 2006; Manea et al., 2017; Manea \& Manea, 2011; Prezzi et al., 2014). All previous studies therefore seem to suggest that the forearc is an area with low surface heat flow in response to the subduction of cold oceanic crust at shallow depths.

These interpretations have recently been challenged by local-scale studies which indicate that part of the thermal variations in the lithosphere of the SCA are not related to the effect of the subducting plate (Astort et al., 2019; Collo et al., 2018; Federico Ibarra \& Prezzi, 2019; Sánchez et al., 2018, 2019; Sigismondi, 2012). For example, Sánchez et al., (2018, 2019) provided evidence for a significant difference in surface heat flow between the orogen (85-95 $\left.\mathrm{mWm}^{-2}\right)$ and the foreland $\left(\sim 45-60 \mathrm{mWm}^{-2}\right)$ at the latitudes of the flat-slab region and proposed structural and/or compositional variations within the crust and different heat-flow input at the base of the lithosphere as possible reasons for this phenomenon. However, none of these hypotheses have yet been validated by a detailed study of the configuration of the lithosphere in terms of its geometry and composition. 
In light of the open questions, we aim to test in this contribution how mantle thermal anomalies and first-order structural and lithological heterogeneities in the overriding plate across and along strike of the subduction system affect the thermal field of the SCA. In order to do so, we followed a data-based modeling approach. Seismic velocities (Assumpção et al., 2013) were converted to temperatures to obtain the deep thermal field in the mantle and across the subduction interface. In the model domains shallower than $50 \mathrm{~km}$, where no mantle shearwave velocity data are available for conversion to temperatures, we calculated the steady-state conductive thermal field. To test the assumption of thermal equilibrium, we analyzed the effects of time-dependent processes related to subduction dynamics by carrying out a transient analysis for the portion of the model domain with lack of constraints from seismic data. Steady-state conductive temperatures in the shallow model domain were computed based on an existing 3D structural and density model of the SCA (Rodriguez Piceda et al., 2021), which is consistent with available geological and geophysical data. We assigned thermal properties according to the lithological characteristics of the sedimentary cover rocks, the crystalline crust, continental lithospheric mantle and oceanic plate, which allowed us to evaluate the control of the lithospheric structure on the resulting temperature distribution. The validity of the inferred thermal structure is assessed by comparison with temperature and surface heat flow measurements available for the studied area and a detailed sensitivity analysis of the model. One main challenge of this approach is related to the sparse coverage of thermal measurements in certain parts of the model. To sort this problem, our results are qualitatively compared with other proxies of the thermal state of the area with larger spatial coverage, including seismic attenuation and elastic thickness patterns. As a result, we have obtained a 3D thermal model of the SCA and adjacent foreland regions that describes the relative temperature variations between the geological units of different composition and lateral and depth extents. Finally, this model allows us to make a qualitative analysis of the thermal feedback mechanisms between these different geological units.

\subsection{Lithospheric configuration of the southern Central Andes}

The main thickness and density variations of the layers constituting the SCA lithosphere were recently described in a 3D lithospheric-scale, density and structural model of the SCA (Rodriguez Piceda et al., 2021). This model was constrained by an array of geological and geophysical data, including seismic reflection and refraction profiles, seismic tomography, sediment-isopach maps, and gravimetric observations (Assumpção et al., 2013; Hayes et al., 2018; Heine, 2007; Ince et al., 2019; Mescua et al., 2016; see references in Rodriguez Piceda 
et al., 2021). The original model covers a region of $700 \mathrm{~km}$ by $1100 \mathrm{~km}$ with a horizontal resolution of $25 \mathrm{~km}$ and a depth of $200 \mathrm{~km}$ below mean sea level (bmsl), comprising the forearc, the Andean orogen, and the foreland regions. The vertical resolution varies as a function of the thickness of the corresponding layers, which were mainly defined on the basis of density contrasts. These layers comprise, from top to bottom: (1) water; (2) marine sediments; (3) continental sediments; (4) upper continental crystalline crust; (5) lower continental crystalline crust; (6) continental lithospheric mantle; (7) shallow oceanic crust; (8) deep oceanic crust; (9) oceanic lithospheric mantle; and (10) oceanic sub-lithospheric mantle. Figure 2 illustrates the main structural features of the 3D model (see Rodriguez Piceda et al. (2021) for more details)

Overall, maximum sedimentary thickness occurs in the Cuyo and Neuquén basins (Fig. 2a). The Andean orogen has thicker crystalline crust $(55 \mathrm{~km})$ than the forearc $(\sim 35 \mathrm{~km})$ and the foreland ( 30 km) (Fig. 2b). The remaining parts of the back-arc and the foreland can be subdivided into three crustal domains: (i) a thick northern domain (40-60 km); (ii) a thin southern domain ( $20 \mathrm{~km})$; and (iii) a central domain with intermediate crustal thickness (35$45 \mathrm{~km})$. The areas with the greatest upper crustal thickness comprise the orogen $(20-40 \mathrm{~km})$ and the Payenia volcanic province $(20 \mathrm{~km})$. In contrast, in the Neuquén Basin the upper crustal thickness thins up to $5 \mathrm{~km}$ (Fig. 2c). The greatest lower crustal thickness ( $\sim 30-45 \mathrm{~km})$ exists in the northern part of the back-arc and foreland regions of the Precordillera and Sierras Pampeanas (Fig. 2d). 

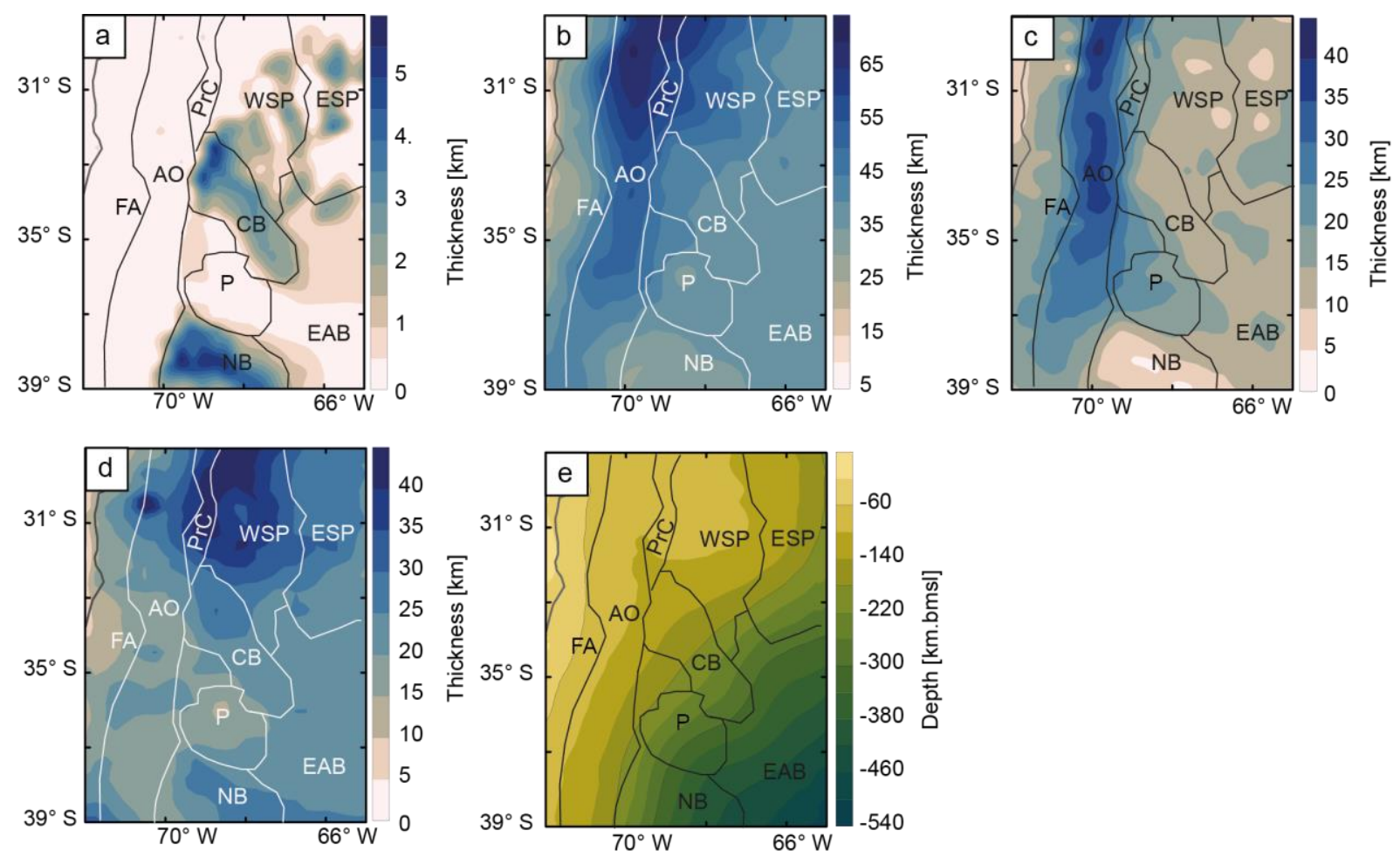

Figure 2. Main structural features of the studied lithosphere from the model of Rodriguez Piceda et al. (2020): thickness of (a) marine and continental sediments; (b) continental crystalline crust; (c) felsic upper continental crystalline crust; (d) mafic lower continental crystalline crust; (e) depth to the subduction interface, coinciding with the top to the oceanic crystalline crust west of the trench and with the top surface of the slab east of the trench.

\section{Modeling approach}

The general workflow followed in this study is illustrated in Figure 3a. Figure $3 \mathrm{~b}$ shows the 3D model box, where different thermal modeling approaches and corresponding thermal boundary conditions were applied. To predict the present-day thermal configuration of the SCA and discuss its controlling factors, we subdivided the model volume into two domains: a deep domain between a depth of 50 and $200 \mathrm{~km} \mathrm{bmsl,} \mathrm{where} \mathrm{temperatures} \mathrm{were} \mathrm{converted} \mathrm{from} S$ wave seismic velocities (here referred to as ' $\mathrm{v}_{\mathrm{s}}$-to-T conversion'); and, a shallow domain, including the crust and uppermost mantle down to a depth of $\sim 50 \mathrm{~km} \mathrm{bmsl,} \mathrm{where} \mathrm{the} \mathrm{steady-}$ state conductive thermal field was calculated using as input the 3D structural and density model of the area (Rodriguez Piceda et al., 2021). The reasons for this subdivision are: the $\mathrm{v}_{\mathrm{s}}$-to-T conversion being developed for application to mantle rocks and the limited quality of mantle velocity data for depths shallower than $50 \mathrm{~km}$. 

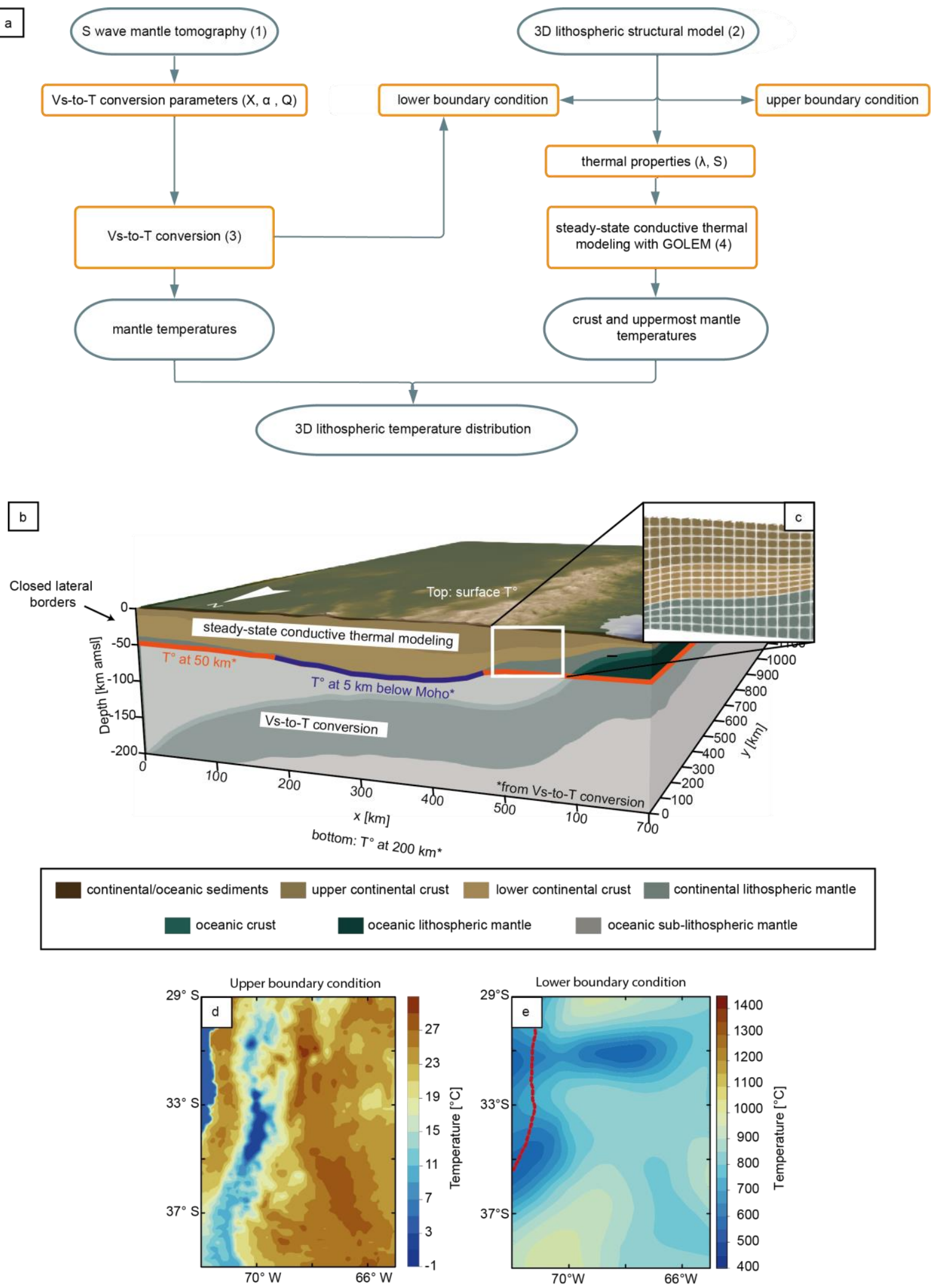

Figure 3. (a) General workflow followed in this study to estimate temperatures in the SCA lithosphere. (b) 3D model box indicating the lithospheric domains where the conversion of seismic velocities (greyshaded area) and the steady-state conductive modeling (non grey-shaded area) were applied. The type of thermal boundary conditions considered for the conductive steady-state modeling are also shown. (c) close-up of Finite Element mesh used for the steady-state conductive thermal modeling. (d) Upper and 
(e) lower boundary conditions applied to the conductive steady-state model. (1) Rodriguez Piceda et al. (2021); (2) Assumpção et al. (2013); (3) (Goes et al. (2000); Meeßen (2017),; (4) Cacace \& Jacquey (2017); Jacquey $\&$ Cacace (2017). $\lambda=$ thermal conductivity, $S=$ radiogenic heat production; $X=$ mantle composition, $\alpha=$ thermal expansion coefficient, $\mathrm{Q}=$ anelasticity.

2.1 Calculation of temperatures in the deep domain

To estimate mantle temperatures between $50 \mathrm{~km}$ and $200 \mathrm{~km}$, we used the results of the $S$ wave mantle tomography of Assumpção et al. (2013). This tomographic model is an updated version of the $S$ wave tomography of Feng et al. (2007) for the South American region, where the velocity structure of the upper mantle was constrained through the joint inversion of $S$ and Rayleigh waveforms and fundamental mode group velocities of Rayleigh waves. The original data set is restricted to depths between $50 \mathrm{~km}$ and $400 \mathrm{~km}$, with a horizontal resolution of approximately $25 \mathrm{~km}$ (Feng et al., 2007). Our choice on the tomography of Assumpção et al. (2013) rather than other global tomographic models covering the study area (Schaeffer \& Lebedev, 2013) stems from the fact that this model has a more refined lateral and vertical resolution, and offers a better spatial correlation between high-velocity features and the track of the slab (Hayes et al., 2018; Fig. S1 in supporting information).

To compute temperatures from $S$ wave velocities, we used the python tool VelocityConversion (Meeßen, 2017) which is a modified version of the original approach by Goes et al. (2000). The method by Goes et al. (2000) is based on laboratory measurements of mantle mineral properties and considers anharmonicity and anelasticity of seismic waves. The equation that relates $\mathrm{v}_{\mathrm{s}}$ in a rock with a given composition $\mathrm{X}$ under a temperature $\mathrm{T}$ and $\mathrm{a}$ pressure $\mathrm{P}$ condition is written as follows:

$v_{S}(P, T, X, \omega)=\sqrt{\frac{\mu(P, T, X)}{\rho(P, T, X)}}-(1-\varepsilon(\omega, T, a)),(1)$

where $\omega$ is the wave frequency, $\mu$ is the shear modulus, $\rho$ is the density, a the frequency exponent, and $\varepsilon$ the attenuation term. $\varepsilon$ is defined as:

$\varepsilon(\omega, T, a)=\frac{2}{Q(\omega, T) \cdot \tan \left(\frac{\pi a}{2}\right)},(2)$

with Q being the attenuation due to anelasticity, described as: 
$Q(\omega, T)=A \cdot \omega^{a} \cdot \exp \left[\frac{a(H+P . V)}{R T}\right]$

where $\mathrm{A}$ and $\mathrm{R}$ are the anelastic and universal gas constants, respectively; $\mathrm{H}$ is the activation energy and $\mathrm{V}$ is the activation volume.

From equation 1 , it is clear that the computation of mantle temperatures requires to define the mantle composition $\mathrm{X}$ described in terms of its main mineral phases (olivine, orthopyroxene, clinopyroxene, and spinel/garnet) and iron content (Goes et al., 2000). For each mineral phase, temperature and pressure (up to $6 \mathrm{GPa}$ ), the density $\rho$ and the elastic modulus $\mathrm{M}$ (shear modulus $\mu$ and/or compressibility $\mathrm{k}$ ) from their values at the reference state $\left(\mathrm{P}_{0}, \mathrm{~T}_{0}\right)$ are calculated as:

$\rho(P, T)=\rho\left(P_{0}, T_{0}\right) \cdot\left[1-\alpha\left(T-T_{0}\right)+\frac{P-P_{0}}{k}\right](4)$

and

$M(P, T)=M\left(P_{0}, T_{0}\right)+\left(T-T_{0}\right) \cdot \frac{\partial M}{\partial T}+\left(P-P_{0}\right) \cdot \frac{\partial M}{\partial P}(5)$

where $\alpha$ is the thermal expansion coefficient.

The implementation by Meeßen (2017) calculates the $\mathrm{v}_{\mathrm{s}}$ and the corresponding density at each depth in the seismic tomography for temperatures between 300 and $3000 \mathrm{~K}$ in steps of $1 \mathrm{~K}$. For the density computation, lithostatic pressure is computed relying on the AK135 seismic model (Kennett et al., 1995). At each grid point, the algorithm compares the computed $\mathrm{v}_{\mathrm{s}}$ with those from the tomographic model, by performing a look- up method over the table and choosing the two closest values to the velocity from the tomography. Then, the temperatures and corresponding densities are linearly interpolated to obtain the final values.

For this study, we chose different mantle compositions (spinel or garnet), listed in Table 1, according to the respective stable aluminum phase at depth (Wyllie, 1981). For shallow depths (50-80 km), a mantle composition corresponding to a spinel lherzolite was assigned, based on mantle xenoliths found in the Payenia volcanic province (Conceição et al., 2005; Jalowitzki et al., 2010). Between $80 \mathrm{~km}$ and $200 \mathrm{~km}$, the stable composition was assumed to correspond to garnet lherzolite (Maaløe \& Aoki, 1977). Mineral properties $\alpha, \rho\left(\mathrm{P}_{0}, \mathrm{~T}_{0}\right)$, $\mathrm{M}\left(\mathrm{P}_{0}, \mathrm{~T}_{0}\right), \partial \mathrm{M} / \partial \mathrm{T}$ and $\partial \mathrm{M} / \partial \mathrm{P}$ were taken Cammarano et al. (2003) and Goes et al. (2000). The thermal expansion coefficient $\alpha$ was assumed constant for each mineral phase. The frequency 
exponent a and anelasticity parameters A, H and V were taken from (Sobolev et al., 1996) (Table 2).

\section{Table 1}

Mantle composition used for the conversion of $v_{s}$ to temperatures (S Goes et al., 2000; Meeßen, 2017)

\begin{tabular}{|l|l|l|l|l|l|l|l|}
\hline Mantle unit & Lithology & Ol & Opx & Cpx & Sp & Gnt & Xfe \\
\hline $50-80 \mathrm{~km}$ & $\begin{array}{l}\text { Spinel } \\
\text { Iherzolite }\end{array}$ & 0.60 & 0.17 & 0.19 & 0.04 & - & 0.10 \\
\hline $80-200 \mathrm{~km}$ & $\begin{array}{l}\text { Garnet } \\
\text { Iherzolite }\end{array}$ & 0.63 & 0.30 & 0.02 & - & 0.05 & 0.08 \\
\hline
\end{tabular}

Note $. \mathrm{Ol}=$ olivine $; \mathrm{Opx}=$ orthopyroxene $; \mathrm{Cpx}=$ clinopyroxene; $\mathrm{Sp}=$ spinel $; \mathrm{Gnt}=$ garnet. The sum of mineral fractions is equal to $1 . \mathrm{Xfe}=$ iron content in molar fraction. Xfe is calculated as $(1-\mathrm{Mg} \#) / 100$, where $\mathrm{Mg \#}$ is the magnesium number.

${ }^{1}$ Conceição et al. (2005); Jalowitzki et al. (2010); ${ }^{2}$ Maaløe \& Aoki (1977)

\section{Table 2}

Anelasticity parameters used for the conversion of $v_{s}$ to temperatures (Sobolev et al., 1996)

\begin{tabular}{|l|l|}
\hline Anelastic constant, $\mathrm{A}$ & 0.48 \\
\hline Activation energy, $\mathrm{H}\left[\mathrm{J} \mathrm{mol}^{-1}\right]$ & $5 \cdot 10^{5}$ \\
\hline Activation volume, $\mathrm{V}\left[\mathrm{m}^{3} \mathrm{~mol}^{-1}\right]$ & $2 \cdot 10^{-5}$ \\
\hline Frequency exponent, a & 0.15 \\
\hline
\end{tabular}

The temperature configuration derived from the $\mathrm{v}_{\mathrm{s}}$-to- $\mathrm{T}$ conversion in the parameter space of $v_{s}$ and depth is shown in Figure 4, which also depicts three 1-D $v_{s}$ profiles representative of the orogen at the latitudes of the flat slab, the steep slab, and the transition zone. In general, temperature increases with increasing depth and decreasing velocity. The largest temperature variations occur for depths shallower than $100 \mathrm{~km}$ and high $\mathrm{v}_{\mathrm{s}}\left(>4.6 \mathrm{~km} \mathrm{~s}^{-}\right.$ $\left.{ }^{1}\right)$, which is characteristic of the flat-slab domain. 


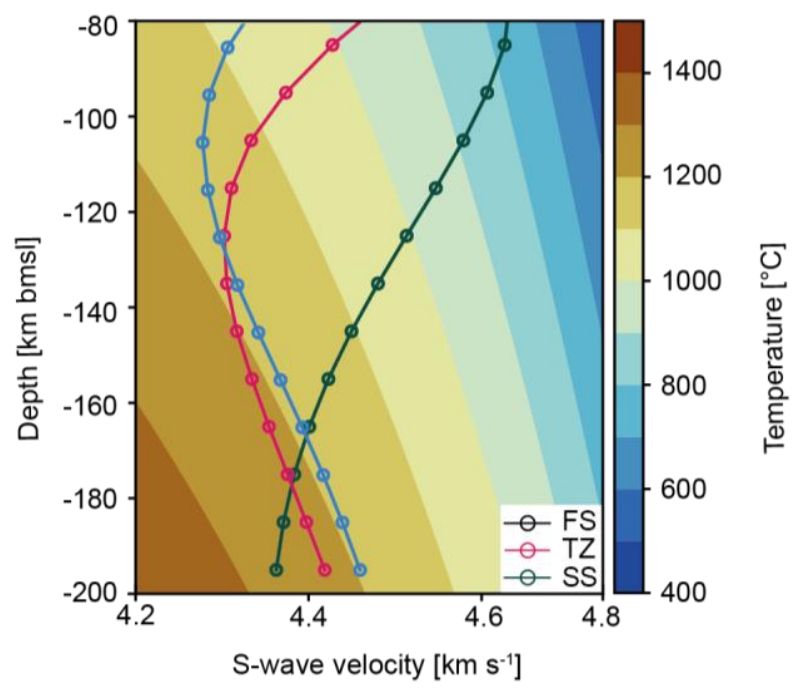

Figure 4. Mantle-temperature distribution as a function of $\mathrm{v}_{\mathrm{s}}$ and depth (obtained using VelocityConversion; Meeßen, 2017) overlain by 1-D $\mathrm{v}_{\mathrm{s}}$ profiles of the seismic tomography of (Assumpção et al., 2013). FS = flat-slab domain; TZ = transition domain; SS = steep-slab domain

\subsubsection{Sensitivity of the $\mathrm{v}_{\mathrm{s}}$-to- $\mathrm{T}$ conversion}

Quantifying uncertainties in the $\mathrm{v}_{\mathrm{s}}$-to-T conversion is difficult due to the combined effects of uncertainties related to the conversion parameters (i.e. anelasticity model, mantle composition, An et al., 2015). An additional source of uncertainty is the $S$ wave tomography, as a $0.1 \%$ perturbation in $\mathrm{V}_{\mathrm{s}}$, for example, can translate into temperature variations of $50^{\circ}-$ $250^{\circ} \mathrm{C}$. Previous studies (An et al., 2015; S Goes et al., 2000) assumed a temperature uncertainty of $150^{\circ} \mathrm{C}$ in the $\mathrm{v}_{\mathrm{s}}$-to-T conversion at Moho depths, but recognized larger uncertainties at greater depths. We therefore reexamined the uncertainty of the conversion method of Goes et al. (2000) by testing the model sensitivity with respect to mantle composition $\mathrm{X}$, thermal expansion coefficient $\alpha$ and attenuation Q. Regarding the conversion method, although several approaches exist (Deschamps et al., 2002; K Priestley \& Mckenzie, 2006; Steinberger \& Calderwood, 2006; Stixrude \& Lithgow-Bertelloni, 2005), we only tested the method of Priestley \& Mckenzie (2006) as implemented by Meeßen (2020) (Model PM). In a first step, we set up a model ('reference model' hereafter) based on the following parametrization: (i) mantle composition $\mathrm{X}$ corresponding to a garnet lherzolite (Table 1); (ii) constant expansion coefficient $\alpha$ and (iii) anelasticity Q by Sobolev et al. (1996) (Table 2). In a second stage, we tested alternative models by varying one parameter at a time: (i) mantle composition (spinel model), (ii) thermal expansion coefficient ( $\alpha$ model) and (iii) attenuation (Q2 Model). In all cases, the conversion was limited to the depth interval of $50-200 \mathrm{~km}$, as thought to be representative of the 
lithospheric mantle. A detailed description of the setup of these alternative models is provided in the Supporting information (Text S1). In section 3.1.1 we discuss in greater details the results from the same sensitivity analysis as applied to the tomography of Assumpção et al. (2013), while in section 4.1.2 we open a discussion on the implications of this sensitivity analysis on the modeled deep thermal field.

2.2 Calculation of temperatures in the shallow domain

To estimate temperatures in the shallow domain (that is in the crust and the mantle above $50 \mathrm{~km}$ ), we used the geometry of the lithospheric layers of the 3D model as described in Section 1.2 (Rodriguez Piceda et al., 2021) as input to solve for the steady state heat conduction equation (Fig 2). Under steady-state conditions, this equation reads as follows:

$\operatorname{div}(\lambda \nabla T)=-S(6)$

where $\mathrm{T}$ is the temperature $(\mathrm{K}), \lambda$ is the bulk thermal conductivity $\left(\mathrm{Wm}^{-1} \mathrm{~K}^{-1}\right)$, and $\mathrm{S}$ is the radiogenic heat production $\left(\mathrm{Wm}^{-3}\right)$. Equation 6 describes the conservation of internal energy under the assumption of thermal equilibrium. This last assumption might be over-restrictive especially for young slabs, where the additional effects from thermal advection from the advancing megathrust might be relevant. We discuss the influence of deviations from thermal equilibrium due to advection of the cold subducting plate in Section 4.1.1.

Temperatures were calculated with the finite element code GOLEM (Cacace \& Jacquey, 2017; Jacquey \& Cacace, 2017). For the thermal computation, three modifications were made to the original 3D configuration. First, the water layer was removed, thus treating the topography/bathymetry as the top of the model (cf. Fig. 1). Second, the horizontal resolution was increased from $25 \mathrm{~km}$ in the original structural model to $5 \mathrm{~km}$ and, third, the layers were vertically refined by a factor of 3 to 32 in order to ensure that (i) each layer has at least three finite elements and (ii) most of the model domain is represented by a cubic finite element to ensure faster numerical convergence (Fig. 3c). These modifications ensured to properly solve the temperatures in each node of the mesh without significantly increasing computational time.

Each unit of the 3D lithospheric model was populated with constant thermal properties (Fig. 3a; bulk conductivity $\lambda$ and radiogenic heat production $S$ ) according to its main lithology (Text S2 in supporting information). The characteristic lithologies, in turn, were selected based on the comparison between gravity-constrained densities (Rodriguez Piceda et al., 2021) and 
mean $P$ wave velocities (Araneda et al., 2003; Contreras-Reyes et al., 2008; Marot et al., 2014; Pesicek et al., 2012; Scarfî \& Barberi, 2019), combined with rock-property compilations (Brocher, 2005; Christensen \& Mooney, 1995) and other seismic properties (Alvarado et al., 2007; 2009; Ammirati et al., 2013, 2015, 2018; Gilbert et al., 2006; Wagner et al., 2005). A range of thermal properties (Čermák \& Rybach, 1982; Hasterok \& Chapman, 2011; He et al., 2008; Vilà et al., 2010; Xu et al., 2004) related to the chosen lithology for each layer was additionally tested until the best fit was achieved with a compilation of borehole temperatures mainly limited to the foreland basins (Collo et al., 2018). Table 3 summarizes the chosen values for each layer of the final (best fitting) model. A sensitivity analysis of the model results to the tested range of the thermal properties indicate that the modeled temperatures are most sensitive to variations in the thermal conductivity of the upper continental crystalline crust and the mantle (Text S3 in supporting information).

Table 4. Lithology and thermal properties assigned to the units of the $3 \mathrm{D}$ structural model (Rodriguez Piceda et al., 2020).

\begin{tabular}{|c|c|c|c|c|}
\hline \multicolumn{2}{|l|}{ Layers } & $\lambda\left[\mathbf{W m}^{-1} \mathrm{~K}^{-1}\right]$ & $\mathrm{S}\left[\mu \mathrm{Wm}^{-3}\right]$ & Lithology \\
\hline \multicolumn{2}{|c|}{ Continental/oceanic sediments } & $2.00^{1}$ & $1.00^{2}$ & siliciclastic \\
\hline \multicolumn{2}{|c|}{ Upper continental crystalline crust } & $3.40^{1}$ & $2.00^{2}$ & dioritoid \\
\hline \multicolumn{2}{|c|}{ Lower continental crystalline crust } & $2.50^{1}$ & $0.40^{3}$ & mafic granulite \\
\hline \multirow{2}{*}{ Oceanic plate } & Shallow crust & $1.80^{1}$ & $0.35^{2}$ & basalt \\
\hline & Deep crust & $2.87^{5}$ & $0.25^{2}$ & eclogite \\
\hline \multicolumn{2}{|c|}{$\begin{array}{l}\text { Continental and Oceanic lithospheric } \\
\text { mantle }\end{array}$} & $2.24^{4}$ & $0.01^{2}$ & $\begin{array}{l}\text { moderately depleted } \\
\text { Iherzolite }\end{array}$ \\
\hline
\end{tabular}

Note. $\lambda=$ bulk thermal conductivity; $\mathrm{S}=$ radiogenic heat production.

${ }^{1}$ Čermák \& Rybach (1982); ${ }^{2}$ Vilà et al. (2010); ${ }^{3}$ Hasterok \& Chapman $(2011) ;{ }^{4}$ Xu et al. $(2004) ;{ }^{5} \mathrm{He}$ et al. (2008)

To close equation 6, Dirichlet boundary conditions (i.e., fixed temperatures) were assigned along the top and base of the model. The upper thermal boundary condition was set at the topography/bathymetry (Fig. 3b), with temperatures extracted from the ERA-5 land database (Copernicus Climate Change Service (C3S), 2019; Fig. 3d, Text S4 in supporting information). The lower boundary condition was set at the depth of the upper bound of the $\mathrm{v}_{\mathrm{s}^{-}}$ 
to-T conversion: a constant depth of $50 \mathrm{~km}$ bmsl for areas where the Moho is shallower than $50 \mathrm{~km}$ bmsl and at a surface $5 \mathrm{~km}$ deeper than the Moho where this interface is deeper than the abovementioned threshold (Fig. 3b). The temperature distribution at this boundary was derived from the $\mathrm{v}_{\mathrm{s}}$-to-T conversion (Fig. 3e; Assumpção et al., 2013); Section 2.2).

\section{Results}

\subsection{Thermal field of the deep domain}

From the conversion of $S$ wave velocities taken from the tomography of Assumpção et al. (2013), we obtained the lower boundary condition of the steady-state conductive model (Fig. 5a) and the mantle-temperature distribution for the $\sim 50-200 \mathrm{~km}$ depth interval (Figs. 5b-d). Across the lower boundary condition, temperatures range between $600^{\circ} \mathrm{C}$ and $1000^{\circ} \mathrm{C}$. Two domains with temperatures of $<700^{\circ} \mathrm{C}$ are identified: (i) a cold nose $(\mathrm{CN})$ between $70^{\circ} \mathrm{W}$ and $72^{\circ} \mathrm{W}$, beneath the forearc in the central and northern portion of the study area and (ii) a domain farther to the east where the slab flattens (FS) between $29.5^{\circ} \mathrm{S}$ and $32.5^{\circ} \mathrm{S}$. The $\mathrm{CN}$ extends eastward above the transition zone and the steep-slab segment and is significantly attenuated above the flat-slab segment (Fig. 5a). With increasing depth (>75 km bmsl), this thermal feature is no longer visible, while the cold FS domain extends vertically over the entire mantle column of the overriding plate (Figs. 5a-c). At $80 \mathrm{~km} \mathrm{bmsl}$, temperature increases to the $\mathrm{SW}$, with maximum values $\left(\sim 1100^{\circ} \mathrm{C}\right.$ ) located between $37^{\circ}-39^{\circ} \mathrm{S}$ and $70^{\circ}-72^{\circ} \mathrm{W}$ (Fig. $5 \mathrm{~b}$ ). At $125 \mathrm{~km}$ bmsl, temperatures follow a similar pattern as at $80 \mathrm{~km}$ depth, but differ in absolute value, with the cold FS domain reaching temperatures between $850^{\circ} \mathrm{C}$ and $900^{\circ} \mathrm{C}$ (Fig. $5 \mathrm{c}$ ). Towards the marine domain and to the south of the study area, temperatures increase up to $1300^{\circ} \mathrm{C}$. At the base of the model $(200 \mathrm{~km} \mathrm{bmsl})$, temperature ranges between $\sim 1200^{\circ} \mathrm{C}$ and $\sim 1350^{\circ} \mathrm{C}$, with the lowest temperatures correlating spatially with the track of the slab (Hayes et al., 2018; Fig. 5d). 


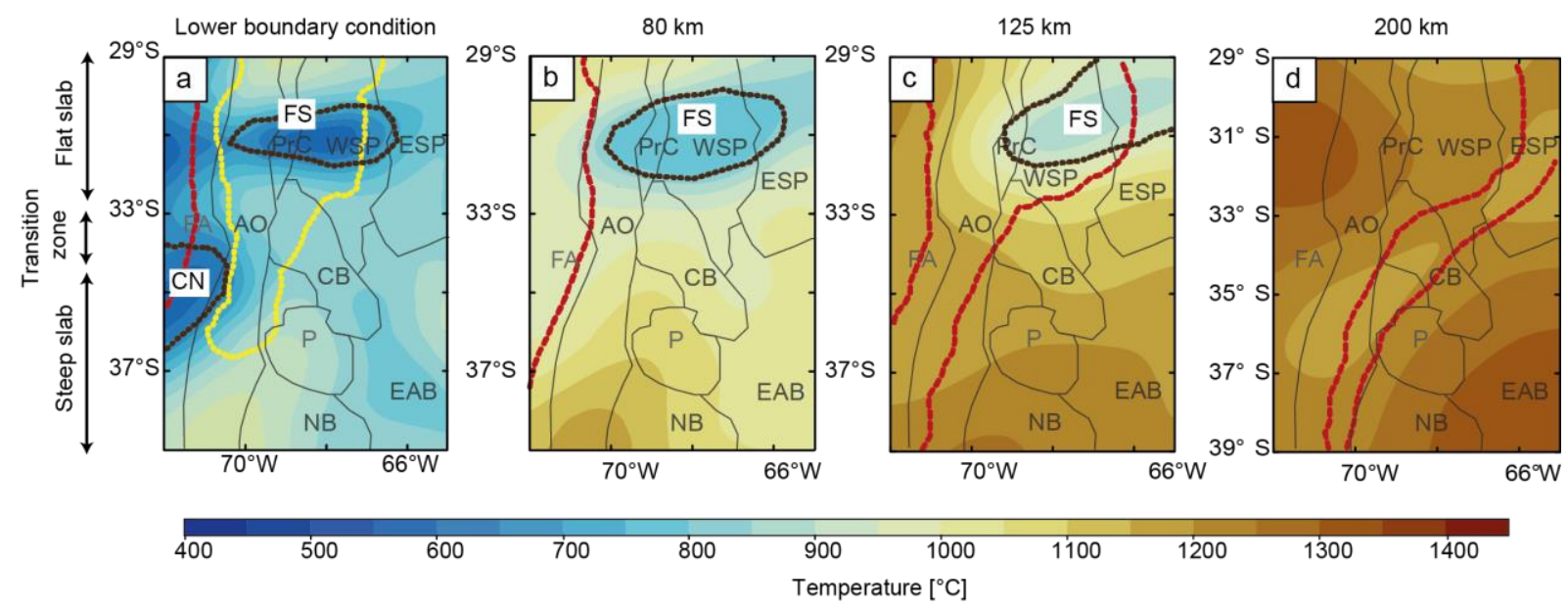

Figure 5. Temperature distribution obtained from the $\mathrm{v}_{\mathrm{s}}$-to-T conversion using the tomography of Assumpção et al. (2013) at depths of: (a) $50 \mathrm{~km}$ bmsl and at $5 \mathrm{~km}$ below the Moho in the interior of the area limited by the yellow line (lower boundary condition of the steady-state model); (b) $80 \mathrm{~km} \mathrm{bmsl}$; (c) $125 \mathrm{~km} \mathrm{bmsl}$; and (d) $200 \mathrm{~km}$ bmsl black lines in a-c indicate the extent of the cold mantle areas: $\mathrm{CN}=$ cold nose, $\mathrm{FS}=$ flat slab. Red lines denote the top and the bottom of the slab (Hayes et al., 2018).

We evaluated the effect of uncertainties in the parametrization of the $\mathrm{v}_{\mathrm{s}}$-to- $\mathrm{T}$ conversion applied to the seismic tomography of Assumpção et al. (2013) by comparing the model described above with alternative model scenarios (for details, see Text S1 in Supporting Information). Figure 6 shows these alternative models in terms of the residual temperature at the lower thermal boundary condition of the steady-state model and at depths of 80,125 and $200 \mathrm{~km}$. The $S$ wave velocity distributions (Assumpção et al., 2013) at those depths are also depicted.

Among the alternative models using the conversion method of (Goes et al. (2000), variation in mantle composition exert the strongest effect on the resulting temperature at shallow depths and where $\mathrm{v}_{\mathrm{s}}$ is $>4.5-4.6 \mathrm{~km} \mathrm{~s}^{-1}$ (up to $200^{\circ} \mathrm{C}$ difference between the reference and the spinel models, Figs. 6e-f). In our study region, $\mathrm{v}_{\mathrm{s}}$ of such high magnitudes characterizes the forearc and the flat-slab segment in the northern part of the foreland (Fig. 6a). Temperature residuals decrease with increasing depth, where lateral variations of $\mathrm{v}_{\mathrm{s}}$ are less distinct. The conversion method of Priestley \& Mckenzie (2006) yields the largest temperature differences among all the alternative models, predicting up to $\pm 400^{\circ} \mathrm{C}$ difference for areas with high $\left(>4.5 \mathrm{~km} \mathrm{~s}^{-1}\right)$ and low $\left(<4.5 \mathrm{~km} \mathrm{~s}^{-1}\right) \mathrm{v}_{\mathrm{s}}$, respectively (Figs. 6q-r). 

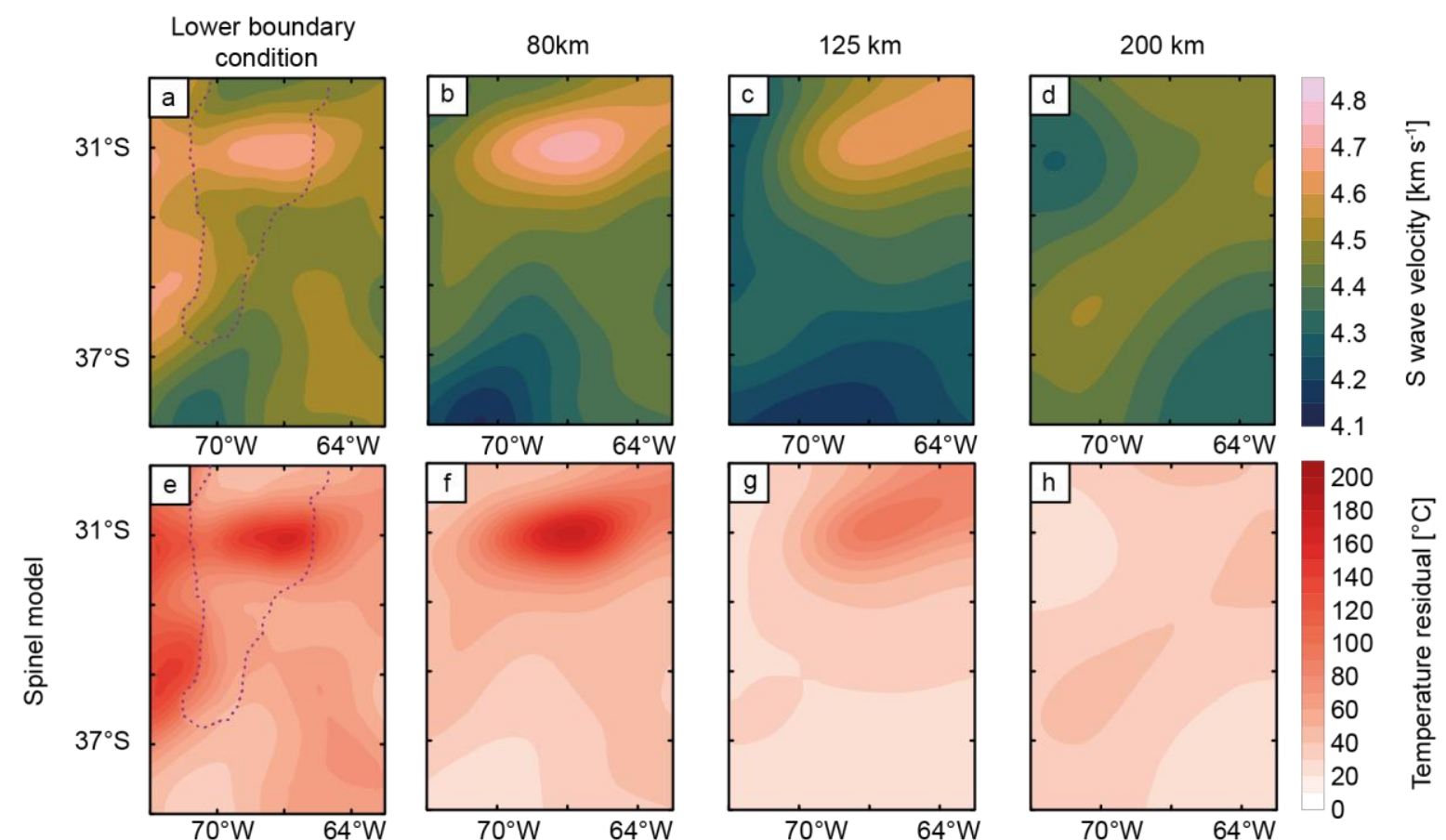

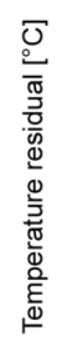
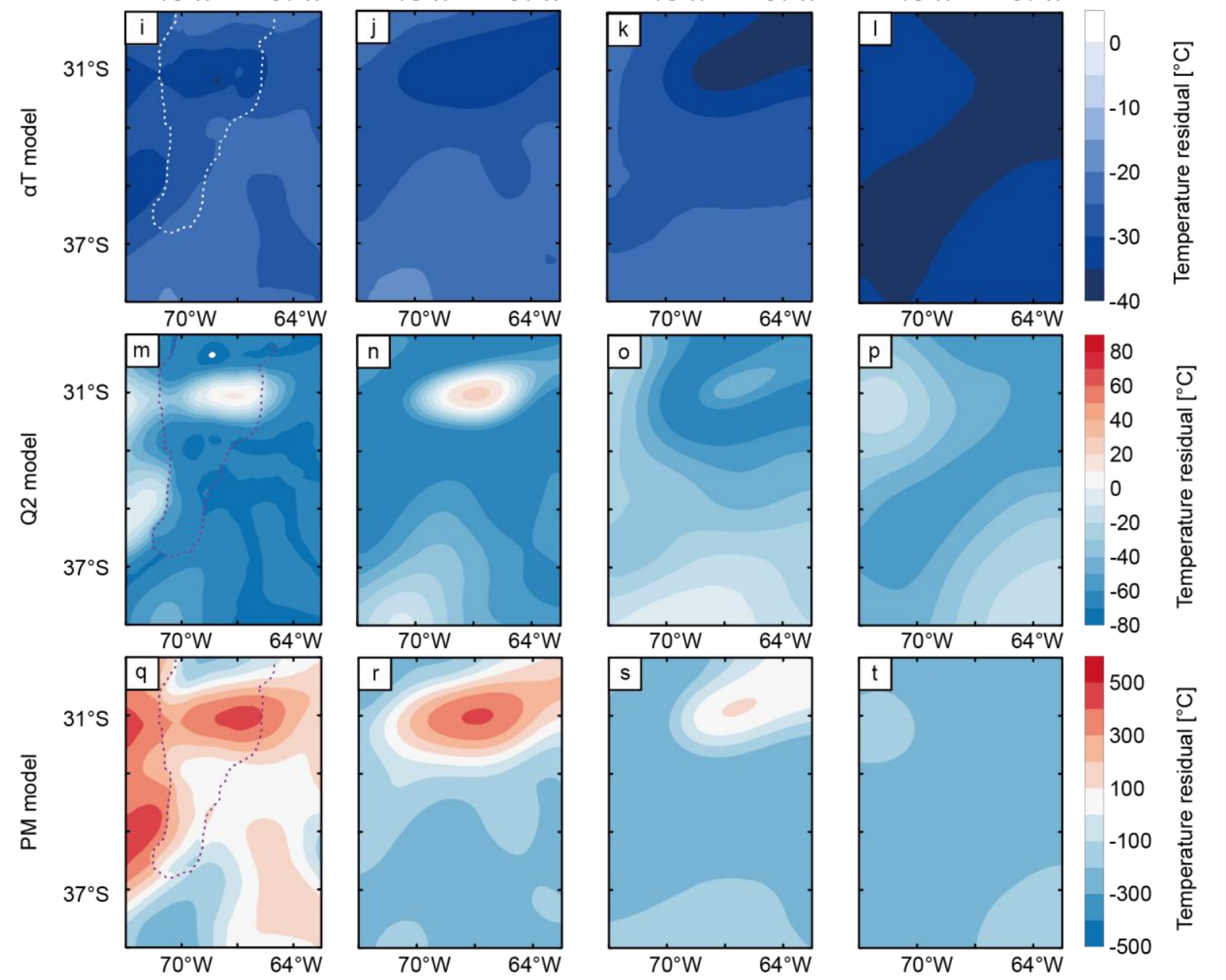

Figure 6. Results from sensitivity analysis of the $\mathrm{v}_{\mathrm{s}}$-to-T conversion (text S1 in supporting information). Slices at depths of the lower boundary condition of the steady state model, 80, 125 and $200 \mathrm{~km} \mathrm{bmsl}$ (below mean sea level) showing the distribution of: (a-d) $\mathrm{S}$ wave velocity from the seismic tomography of Assumpção et al. (2013) ; (e-t) Temperature residual (difference between the temperature fields of 
the reference model and each alternative configuration). (e-h) spinel model: with mantle composition of spinel lherzolite (Conceição et al., 2005; Jalowitzki et al., 2010); (i-1) $\alpha \mathrm{T}$ model: with temperaturedependent thermal expansion coefficient (Cammarano et al., 2003; S Goes et al., 2000; Saxena \& Shen, 1992); (m-p): Q2 model: with anelasticity parameters from Berckhemer et al., (1982); (q-t) PM model: with $\mathrm{v}_{\mathrm{s}}$-to-T conversion following (K Priestley \& Mckenzie, 2006). The dotted line in Figs. a, e, i, m and q marks the $45 \mathrm{~km}$ depth contour of the Moho.

\subsection{Thermal field of the shallow domain}

From the steady-state conductive approach, we computed the thermal field of the crust and uppermost mantle to the depth of the lower boundary condition. Figure 7 shows the temperature distribution at depths of 2, 5, 10, 20, 25, 30, 35, 40, $45 \mathrm{~km}$ bmsl and of the Moho. At $2 \mathrm{~km}$ bmsl, temperatures range between $15^{\circ} \mathrm{C}$ and $165^{\circ} \mathrm{C}$ (Fig. 7a). As expected, the warmest areas are those with the highest topography (4-6 km height; cf. Fig. 1) and the largest upper crustal thickness (30-40 km, cf. Fig. 2c), which correspond to the central and northern segments of the Andean orogen. In addition, the forearc is characterized by an overall lower temperature than the orogen $\left(40^{\circ}-80^{\circ} \mathrm{C}\right)$, but by a more pronounced lateral gradient with values increasing toward the Andes. The foreland and low-elevation back-arc regions are characterized by a wide temperature range $\left(60^{\circ}-115^{\circ} \mathrm{C}\right)$, with warmer temperatures in the Precordillera, the Payenia volcanic province, and the Cuyo and Neuquén basins. Down to $25 \mathrm{~km} \mathrm{bmsl,} \mathrm{the} \mathrm{spatial} \mathrm{trends}$ of temperature distribution are similar to those observed at shallow depths, but with different absolute values (Figs. 7b-e).

The thermal contrast between the warm orogen and the relatively cold forearc, back-arc, and foreland regions is more pronounced with increasing depth (e.g., $\sim 110^{\circ} \mathrm{C}$ at $10 \mathrm{~km} \mathrm{bmsl}$ and $\sim 200^{\circ} \mathrm{C}$ at $20 \mathrm{~km}$ bmsl.; Figs. $7 \mathrm{c}-\mathrm{d}$ ). From $20 \mathrm{~km}$ bmsl downward, the temperature distribution partially resembles that of the lower boundary condition (Fig. 5a). Lowest temperatures at these depths correlate spatially with the areas where the mantle is the coldest (CN and FS areas, Fig. 5a). Here, the temperature minimum also correlates with a thick ( 40 km, cf. Fig. 2b) continental crystalline crust, where the lower crust is also thickened (>30 km, cf. Fig. $2 d)$. 

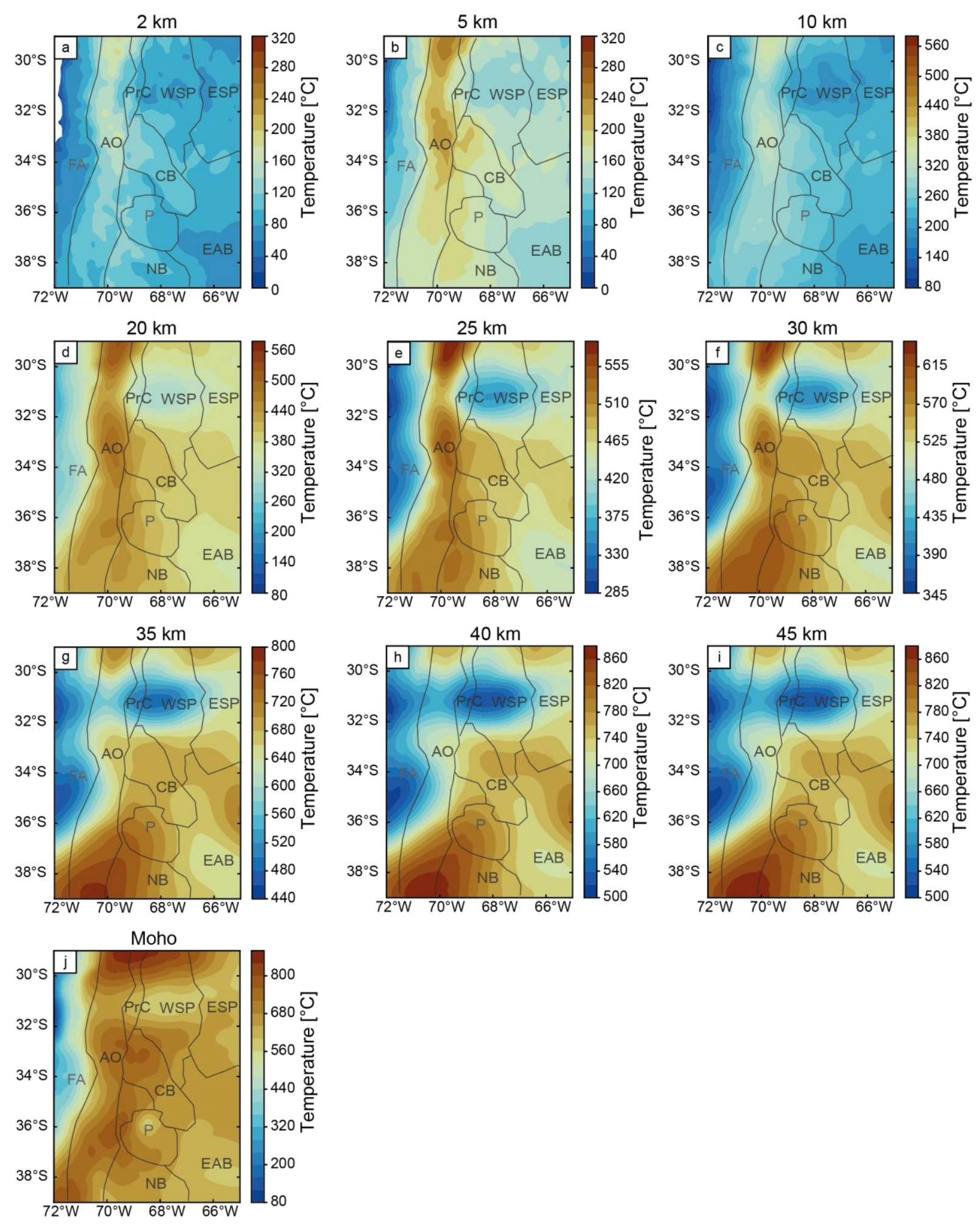

Figure 7. Modeled temperature distribution below sea level at different depths: (a) $2 \mathrm{~km}$, (b) $5 \mathrm{~km}$, (c) $10 \mathrm{~km}$, (d) $20 \mathrm{~km}$, (e) $25 \mathrm{~km}$, (f) $30 \mathrm{~km}$, (g) $35 \mathrm{~km}$, (h) $40 \mathrm{~km}$, (i) $45 \mathrm{~km}$, and (j) Moho. Boundaries of the main morphotectonic provinces are also marked with black lines; for abbreviations see Fig. 1 
From the modeled thermal field, we computed the surface heat flow (Text S5 in Supporting Information, which varies laterally from minima of $\sim 45-70 \mathrm{mWm}^{-2}$ in the oceanic domain, most of the forearc, and foreland to maxima across the orogen $\left(80-100 \mathrm{mWm}^{-2}\right.$; Figure 8). We observe a remarkable spatial correlation between the surface heat-flow distribution and continental crustal features. Whereas high heat flow corresponds to areas with thick upper continental crystalline crust (>25 km; e.g., within the orogen and the Payenia volcanic province; cf. Fig. 2c), low heat flow characterizes the deep sedimentary basins ( >3 km; e.g., the Neuquén Basin; cf. Fig. 2a) and/or thick lower continental crystalline crust (>25 km; e.g., most of the Sierras Pampeanas; cf. Fig. 2d).

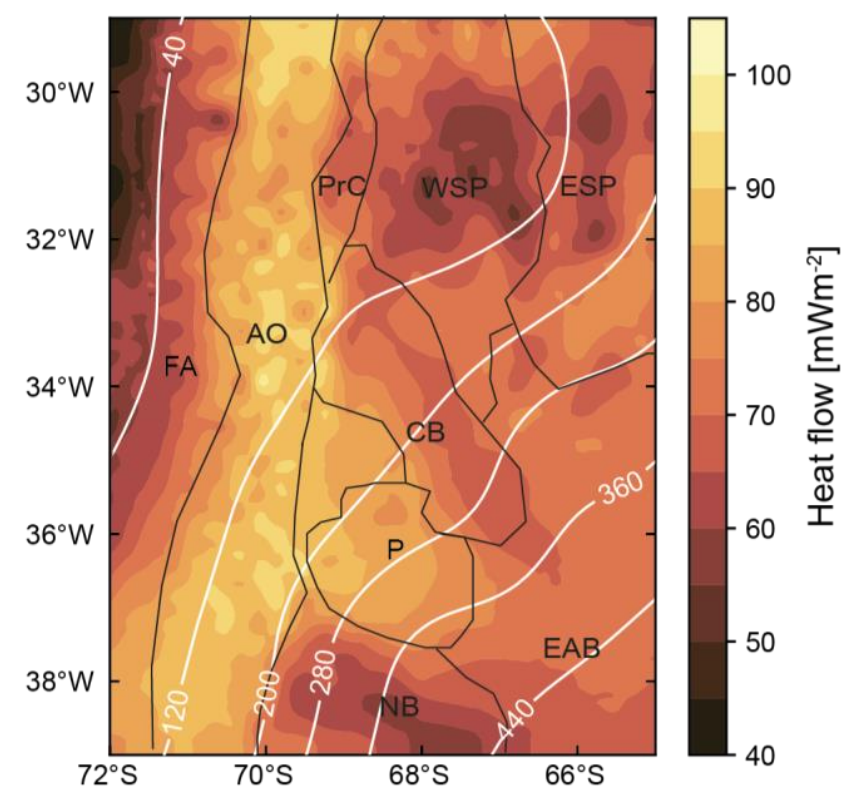

Figure 8. Modeled surface heat flow. Depth contours $(\mathrm{km})$ of the top of the oceanic crust from SLAB2 (Hayes et al., 2018) are shown in white lines. Boundaries of the main morphotectonic provinces are also marked with black lines; for abbreviations see Fig. 1

\subsection{Model validation}

As a first step in the validation process, we compared modeled temperature values with the published borehole measurements of Collo et al. (2018), located mainly in the central and northern foreland (Fig. 9a). The residual temperature (i.e., the difference between modeled and measured values) is shown in Fig. 9b. Figure 9c illustrates measured and modeled temperatures vs. depth, and Figure 9d shows the residual temperature $\mathrm{v}_{\mathrm{s}}$. depth. In general, we obtain a good 
fit of approximately $\pm 20^{\circ} \mathrm{C}$ between the borehole data and the modeled temperatures, with the exception of few outliers (Fig. 9c).

Albeit limited in coverage, in a second step we used available compilations of surface heatflow values within the SCA (Hamza \& Muñoz, 1996; Lucazeau, 2019; Uyeda \& Watanabe, 1982) to validate our thermal model. These measurements are located mainly along the orogenic axis and show a large variation in their magnitudes (up to $250 \mathrm{mWm}^{-2}$ ), even between close measurements (Fig. 9a). Figure 9b depicts the residual surface heat flow, i.e., the difference between the predicted and the measured surface heat flow, at the location of the measurements. Figure $9 \mathrm{e}$ is a histogram of residuals of surface heat flow. In general, the model underestimates the surface heat flow with respect to the measured values, with only $\sim 25 \%$ of the predictions matching the observations (Fig. 9e). Due to its purely conductive nature, the model does not reproduce the extremely high heat flow $\left(>150 \mathrm{mWm}^{-2}\right)$ reported for some volcanic areas in the axial sectors of the orogen. Additionally, due to its resolution, the model is not able to reproduce the observed variations in heat-flow magnitudes between adjacent measurements, which likely correlate to local features not considered in our regional study (Fig. 9b). 

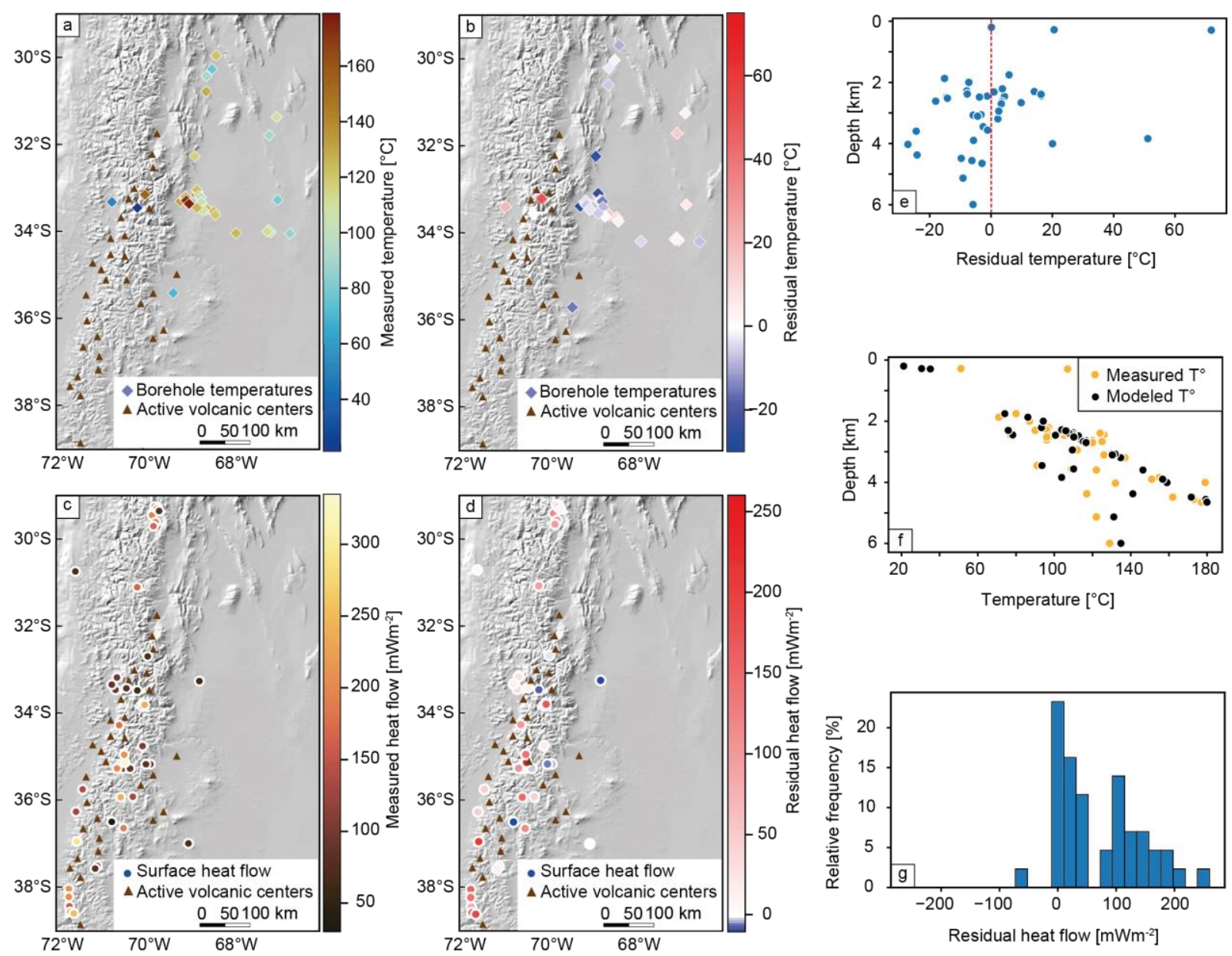

Figure 9. Shaded-relief image of the study area with superposed location of: (a) borehole temperatures (diamonds, Collo et al., 2018), (b) residual temperature, (c) observed surface heat flow (circles, Hamza \& Muñoz, 1996; Uyeda \& Watanabe, 1982); and (d) residual surface heat flow. Residual values are obtained from the subtraction between observed and modeled values. Triangles in (a-d) show the location of active volcanic centers. (c) Comparison between measured (orange) and modeled (black) temperatures vs. depth. (d) Residual temperature vs. depth. (e) Histogram of residual heat flow.

\section{Discussion}

\subsection{Model robustness and sensitivity analysis}

\subsubsection{Steady-state assumption in the shallow lithosphere domain}

One main assumption in the calculation of the shallow temperature field was to consider that the lithosphere is in steady state. However, thermal equilibrium in the overriding plate can be disturbed by the advection of the cold subducting plate (e.g., Holt \& Condit, 2021; Leng \& Mao, 2015). Therefore, a more appropriate modeling strategy would be to additionally account for these processes. The caveat here is that performing such an analysis requires a detailed 
knowledge of the past temperature distribution in order to properly initialize the system. Unfortunately, we lack such constraints in the SCA. Given these considerations, we relied in our study on the assumption of steady-state conduction, where the results are less affected by the choice of the initial temperature condition, but are mainly determined by the imposed boundary conditions (based on available observables in our study) and the model parameterization. Nonetheless, in an attempt to quantify the validity of this approximation for the SCA, we also computed a simulation that accounts for the additional effects of advection of cold temperatures due to the motion of the subducting slab on the present-day thermal field of the shallow domain. To that end, we first computed the resulting thermal field from the advection of a cold thermal front along the subduction interface (i.e., top of the oceanic crust). In a following step, we imposed this thermal evolution as the lower boundary condition on the $3 \mathrm{D}$ configuration of the overriding plate, and ran a transient simulation with a duration of $7 \mathrm{Ma}$, which represents the past period during which the subduction geometry remained unchanged (Jordan et al., 1983; Ramos et al., 2002). A detailed description is provided in the supporting information (Text S6). The comparison between the initial and final time steps at representative depth slices (10 and $40 \mathrm{~km} \mathrm{bmsl}$ ) indicates that the largest temperature difference (up to $450^{\circ} \mathrm{C}$ ) is registered in a narrow band within the forearc close to the subduction interface (Fig. 10). Such a difference is due to the advection of the cold thermal front along this interface. In the remaining areas, temperatures at $7 \mathrm{Ma}$ are up to $10^{\circ} \mathrm{C}$ higher than the initial time step due to diffusion within the thick radiogenic crust in the orogen. In view of these results, we consider the assumption of thermal equilibrium as an adequate approximation for the thermal calculations of the shallow domain of the overriding plate in the SCA. 

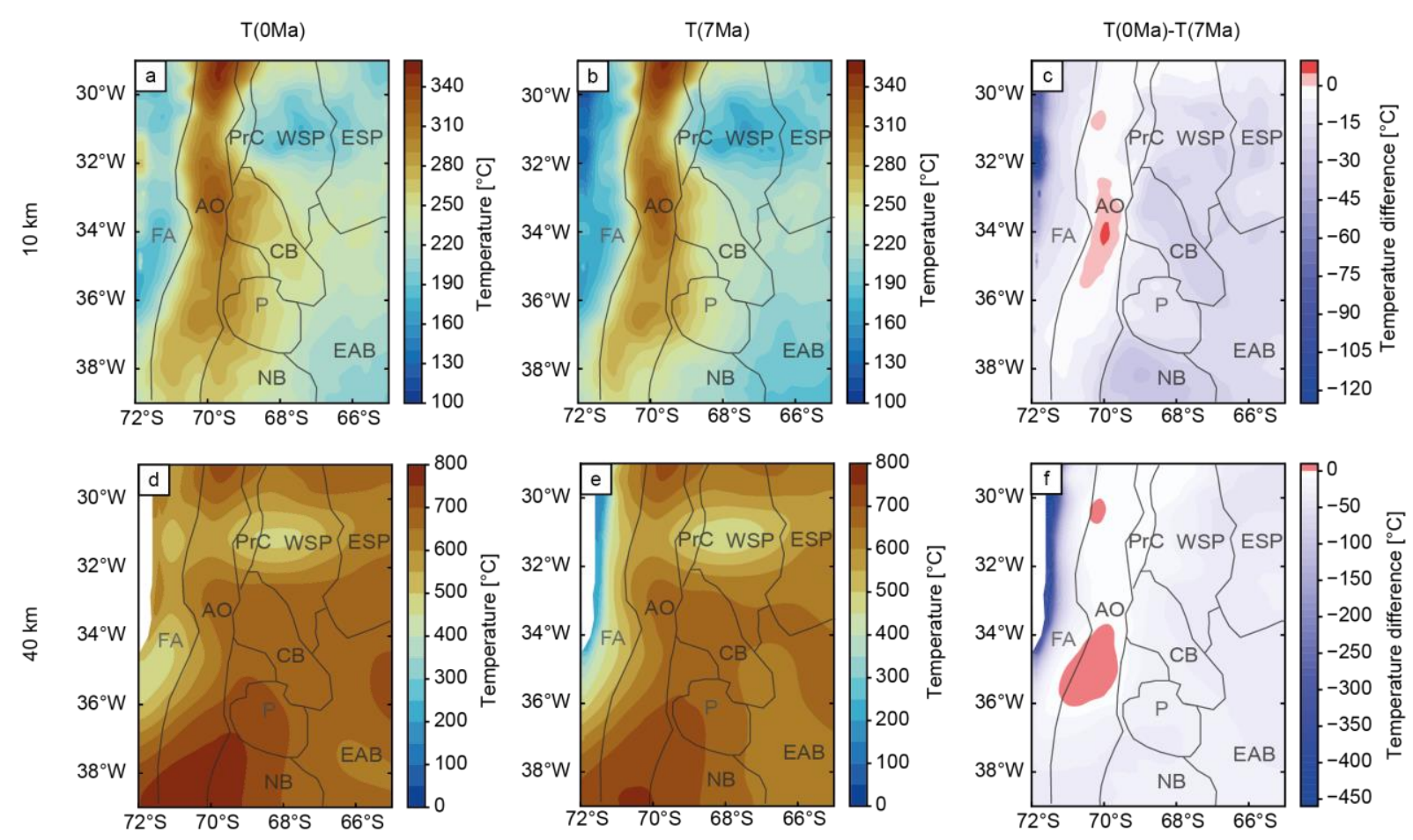

Figure 10: Transient temperature distribution in the overriding plate at depths of 10 and $40 \mathrm{~km}(\mathrm{a}, \mathrm{b}$, and c), as induced by the advection at the subduction interface at 0 Ma and 7 Ma time steps. (c) and (f) show the temperature difference between (b) and (a), and (e) and (d), respectively. Boundaries of the main morphotectonic provinces are also marked with black lines. For abbreviations see Fig. 1.

\subsubsection{Implications of the methodological uncertainties and limitations on the lithospheric thermal field}

The model results depend on the parametrization of physical properties and boundary conditions. One source of uncertainty is the $\mathrm{v}_{\mathrm{s}}$-to-T conversion. Sensitivity analysis of the $\mathrm{v}_{\mathrm{s}^{-}}$ to-conversion shows that within the tested alternative models, using the conversion method of Priestley \& Mckenzie (2006) and changing the mantle composition based on Goes et al. (2000) yield the largest temperature differences with respect to the reference model (Fig. 6). In contrast, variations in the thermal expansion coefficient $\alpha$ and attenuation $Q$ has a negligible effect on the inverted thermal field. Since the conversion method of Priestley \& McKenzie (2006) is associated with large uncertainties $\left(250^{\circ}-360^{\circ} \mathrm{C}\right.$ ) for temperatures $<900^{\circ} \mathrm{C}$ (An et al., 2015; Priestley \& McKenzie, 2013), we limit our discussion to computed temperature variations due to considered variations in the mantle composition based on the approach by Goes et al. (2000)

The temperature difference between the reference and alternative models is only significant in a limited portion of the shallow mantle $(<100 \mathrm{~km})$ characterized by high $\mathrm{v}_{\mathrm{s}}(>4.6$ $\mathrm{km} \mathrm{s}^{-1}$ ), as is the case for the flat-slab segment and the forearc (Fig. 6). Moreover, the regional 
thermal pattern in the mantle (i.e., the thermal contrast between the flat- and steep-slab segments) is a robust feature common to all model configurations despite variations in mantle composition. To quantify the sensitivity of the shallow thermal field to imposed variations in the mantle composition, we carried out an additional model for which we imposed as a lower boundary condition the resulting temperature distribution obtained from the conversion considering a garnet lherzolite mineral composition (Table 1). Temperature maps showing the difference between the two models are provided in the supporting information (Fig. S10). Although the model with the alternative lower boundary condition predicts temperatures that are up to $80^{\circ} \mathrm{C}$ higher than the reference model described in Section 3.2, the regional thermal heterogeneity remains unchanged, with contrasts between the forearc, orogen, and foreland, and between the flat- and steep-slab segments. From these observations, we can conclude that the modeled trends in temperature variations are within the same order of magnitudes, though still within its range of uncertainty, even when considering an alternative parametrization other than the preferred $\mathrm{v}_{\mathrm{s}}$-to-T conversion model.

Another limitation of the $\mathrm{v}_{\mathrm{s}}$-to-T conversion is related to the thermal structure within the slab. Although the oceanic plate displays higher Vs and lower temperatures with respect to the surrounding mantle (e.g. Fig. 5; Fig. S1 in Supporting information), the model thermal gradient within the plate is not as large as the one predicted by other analytical or numerical approximations of the thermal structures of subduction zones (England, 2018; van Keken et al., 2019). The strong lateral contrasts of $v_{s}$ are smoothed due to the resolution of the seismic tomography. This results in lower $\mathrm{v}_{\mathrm{s}}$ and therefore higher temperatures than the predictions of these theoretical thermal models. On the contrary, $\mathrm{v}_{\mathrm{s}}$ and resulting temperature anomalies within the continental mantle are of larger wavelength than those of the slab, thus they can be captured by the longer wavelength surface waves of the seismic tomography. Therefore, our discussion was limited to the thermal heterogeneities of the overriding plate and subduction interface.

Additional methodological uncertainties relate to the limited resolution, coverage, and lateral differentiation of the lithospheric units in the 3D structural model, as well as to imposed thermal properties. Although there is an inherent non-uniqueness in the way thermal properties influence the results, the range over which these properties can vary is limited (see Text S3 in the supporting information). In addition to testing the effect of end-member property values, the use of a wide variety of independent lithology-constraining data sets, including borehole temperatures, seismic tomography, seismic reflection and refraction data, and gravity 
anomalies, helped reduce the range of property variability. Future improvement of the definition of higher-order temperature contrasts relies on more densely spaced seismic experiments focused on the deep crustal structure of the SCA and more extensive temperature measurements to cross-check the modeling results. First-order thermal effects proved to be robust even for tested variations in imposed properties.

\subsection{Controlling factors of the lithospheric thermal field}

Our results indicate that the shallow thermal field of the lithosphere $(<50 \mathrm{~km})$ is largely controlled by the configuration of the continental crust, with temperatures varying according to the thickness of the sedimentary rocks and crystalline crust. Close to the surface $(<5 \mathrm{~km})$, thick sedimentary basins (main depocenters of the Cuyo and Neuquén basins) exhibit temperatures up to $\sim 40^{\circ} \mathrm{C}$ higher than at the basin margins. This is the effect of thermal blanketing produced by the low-conductive sedimentary layers (Lucazeau \& Le Douaran, 1985; Scheck-Wenderoth et al., 2014; Sippel et al., 2017; Wangen, 1994). In contrast, the presence of more thermally conductive crystalline rocks leads to a more efficient heat transport where sedimentary cover rocks are absent and to colder shallow temperature at the same depth.

In the areas where the sedimentary units are thin $(<2 \mathrm{~km}$ thick) or absent, the variations in the topographic relief and in the upper continental crystalline crust exert the primary influence on the shallow thermal field. This topographic effect is related to the general increase in temperature with depth, which results in higher temperatures in the orogen than in the foreland at the same depth below sea level. The positive correlation between thickness of the upper continental crystalline crust and higher heat budget compared to the other lithospheric layers stems from these rocks being enriched in radioactive heat-producing elements due to their felsic composition (Vilà et al., 2010). These two superposed effects increase crustal temperatures in areas with high elevation $(>1.5 \mathrm{~km}$ above mean sea level, amsl) and pronounced upper crustal thickness $(>20 \mathrm{~km})$. These characteristics are particularly evident in the Andean orogen, where temperatures at $2 \mathrm{~km} \mathrm{bmsl}$ are up to $100^{\circ} \mathrm{C}$ higher with respect to the forearc, the remaining back-arc, and the foreland regions. Outside of the orogen, the average elevation and the upper continental crystalline crustal thickness decreases to $700 \mathrm{~m}$ amsl and $10 \mathrm{~km}$, respectively, and consequently the thermal input also decreases. To further examine the effects of topographic relief and upper crustal thickness on the shallow thermal field, we extracted the 
temperatures at 2 and $20 \mathrm{~km}$ below sea level $\left(\mathrm{T}_{\mathrm{z}(\mathrm{bmsl})}\right)$ and below surface $\left(\mathrm{T}_{\mathrm{z}(\mathrm{topo})}\right)$ and computed the difference between the two reference levels $\left(\mathrm{T}_{\text {diff }}\right)$ for each depth:

$T_{\text {diff }}=T_{z(\text { bmsl })}-T_{z(\text { topo })}(7)$

The temperature differences at $2 \mathrm{~km}$ and $20 \mathrm{~km}$ are shown in Figure 11 . We observe that at shallow depths of $2 \mathrm{~km}$, the temperature differences are indeed affected by variations in the topography $\left(\sim 100^{\circ} \mathrm{C}\right.$ in areas of 3-6 km elevation). This effect decreases with greater depth, although it is still evident at $20 \mathrm{~km}$ bmsl, where temperature differences are up to $50^{\circ} \mathrm{C}$ below areas of 5-6 km topographic elevation. Below $20 \mathrm{~km}$ bmsl, the influence of the upper crustal thickness outweighs the topographic effect.
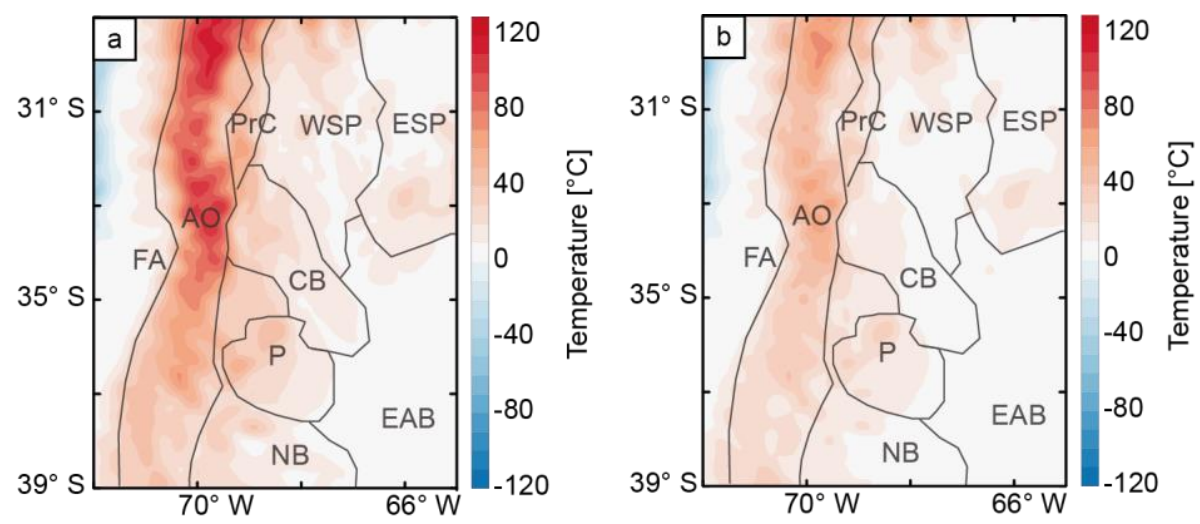

Figure 11. Difference between temperature distributions below sea level and below surface at depths of (a) $2 \mathrm{~km}$ and (b) $20 \mathrm{~km}$, illustrating the topographic effect on the thermal field. Key morphotectonic provinces are shown. Refer to Fig. 1 for abbreviations.

Our results confirm that the lithospheric thermal field is influenced by both the cooling effect of the subducting slab and heat input from the mantle, and that below $50 \mathrm{~km}$ bmsl these two factors play a dominant role. The degree to which the slab dynamics affects the temperature distribution by advective cooling varies with distance from the trench and the subduction angle. To better illustrate this relationship, we obtained the overall 3D thermal field by combining the calculated steady-state conductive thermal field above the lower boundary condition $(50-\mathrm{km}$ approximation) with the temperatures deduced from seismic tomography between 50 and 200 $\mathrm{km}$ bmsl. From this combined model, the temperatures corresponding to the depth of the subduction interface as presented by Rodriguez Piceda et al. (2021) and the volumetric extent of the low-temperature CN and FS mantle domains were extracted (Fig. 12). These domains were defined according to the regions of the mantle of the overriding plate with temperatures 
lower than those of a typical continental geotherm (McKenzie et al., 2005). The mantle of the overriding plate exhibits the lowest temperatures close to the trench, within the cold nose of the forearc, and where the slab flattens (mostly at $85 \mathrm{~km}$ bmsl beneath the Sierras Pampeanas). In contrast, temperatures at depths $>50 \mathrm{~km}$ bmsl beneath the Sierras Pampeanas increase towards areas where the slab dips steeply $\left(\sim 30^{\circ}\right)$. These results are consistent with the lower surface heat-flow values observed (Hamza et al., 2005, 2005; Valiya M. Hamza \& Muñoz, 1996; Uyeda \& Watanabe, 1982) and low $\mathrm{v}_{\mathrm{p}} / \mathrm{v}_{\mathrm{s}}$ ratios modeled (Marot et al., 2014; Porter et al., 2012; L. S. Wagner et al., 2005, 2005) for the flat-slab area. An additional and independent constraint for the thermal state of the flat-slab area can be derived from the results from $2 \mathrm{D}$ thermomechanical modeling efforts done in the area (Marot et al., 2014), which suggested temperatures of $600^{\circ} \mathrm{C}$ at the top of the flat slab (100-120 km bmsl). This value coincides with the lower temperatures modeled across the subduction interface beneath the Sierras Pampeanas (Fig. 13).

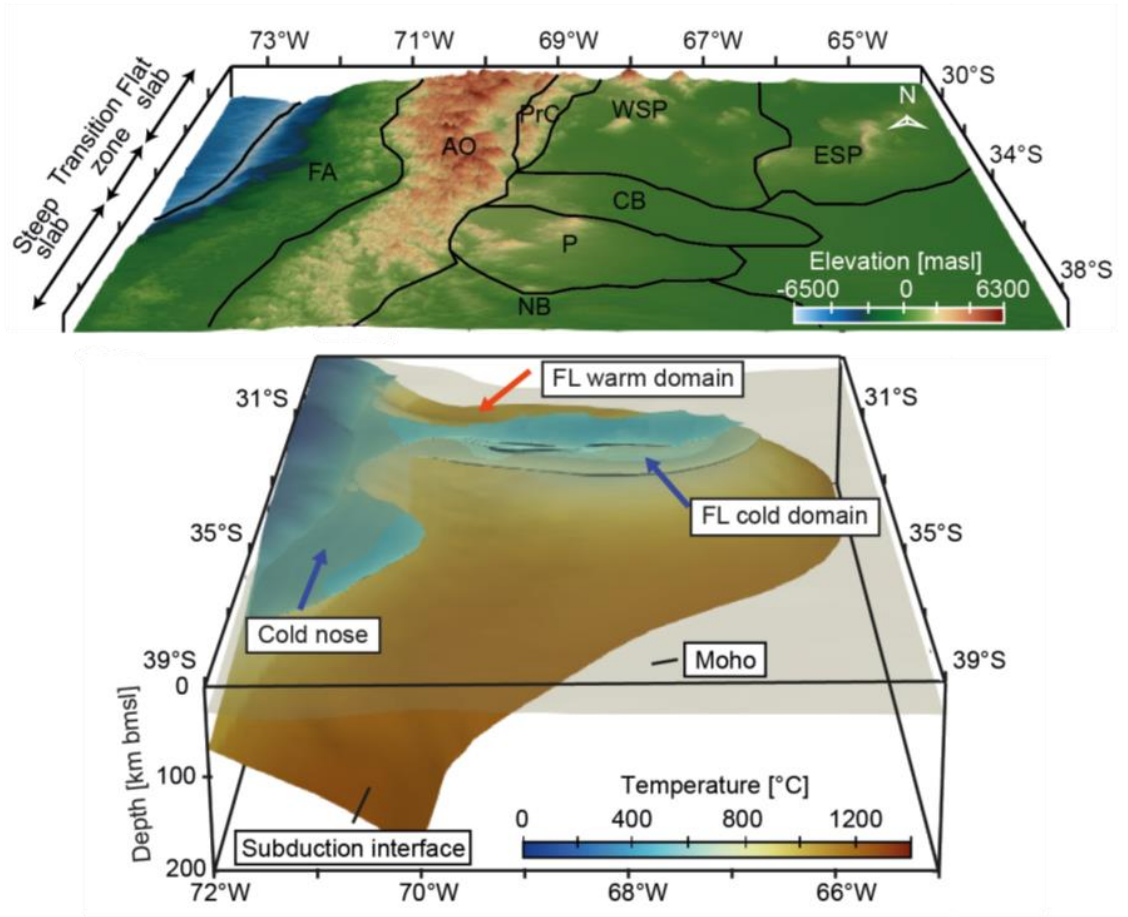

Figure 12. Upper panel: Topography of the study region superposed with boundaries of the main morphotectonic provinces (for abbreviations see Fig. 1). The extent of the subduction segments and the trench are also shown. Lower panel: Temperature at the subduction interface. The 3D configuration of cold domains in the overriding plate mantle is superimposed and indicated by blue arrows, The red arrow indicates the warmest part $\left(\sim 1000^{\circ} \mathrm{C}\right)$ of the flat-slab segment. The extent of the Moho is shown by the beige transparent layer. 
The spatial correlation between the temperature distribution of the overriding plate and the subduction angle breaks within the northern orogen above the flat slab between 20 and 100 $\mathrm{km}$ bmsl $\left(29^{\circ}-30^{\circ} \mathrm{S}\right.$ and $70^{\circ}-70.5^{\circ} \mathrm{W}$; Figs. 5, 7, 12). In this domain, a temperature excess of up to $\sim 250^{\circ} \mathrm{C}$ is predicted along the remaining flat-slab segment, with values similar to those of the steep-slab segment (FL warm domain; Fig. 13). To explain the modeled temperature distribution, an additional forcing factor other than the subduction angle should be considered, a suggestion that has been discussed previously, albeit not extensively (Sánchez et al., 2018, 2019). Between $30^{\circ}$ and $33^{\circ} \mathrm{S}$, our results indicate a spatial correlation between the thermal heterogeneity derived from the $\mathrm{v}_{\mathrm{s}}$-to-T conversion (Assumpção et al., 2013) and the configuration of the upper crust. The lowest temperatures in the sub-horizontal slab segment occur where the upper crust is thin, while the highest temperatures occur where it thickens (cf. Fig. 2c). We can therefore postulate that, in the warmer, northern part of the orogen, heating from a thicker upper continental crystalline crust outweighs the cooling effect of the underlying flat oceanic slab. Conversely, areas in the flat segment with a thin upper crust and a thick lower crystalline crust are significantly colder due to a limited volumetric contribution of the lower crustal unit to the internal heat budget. North of $30^{\circ} \mathrm{S}$, the thick upper crust provides an explanation for the observed patterns of low $\mathrm{v}_{\mathrm{s}}$ and high temperature in the orogen, but not in the foreland regions where the upper crust is thinner. It is likely that the resolution of the $S$ wave tomography could have influenced the results within the latter area. North of the flat slab, highresolution tomography (Calixto et al., 2013; Gao et al., 2021) identifies a N-S increase of $\mathrm{v}_{\mathrm{s}}$ at $27^{\circ} \mathrm{S}$ with a sharp transition between low $\mathrm{v}_{\mathrm{s}}$ in the southern Andean Plateau (also known as the southern Puna Plateau) and high $\mathrm{v}_{\mathrm{s}}$ in the Sierras Pampeanas. Low $\mathrm{v}_{\mathrm{s}}$ in the southern Puna is mainly associated with the delamination of the lower crust and the mantle (Kay et al., 1994; Schurr et al., 2006). Therefore, we postulate that this sharp velocity transition appears smoothed in the tomography of Assumpção et al. (2013) due to the coarser resolution, resulting in lower modeled $\mathrm{v}_{\mathrm{s}}$, and therefore higher temperatures, in the foreland north of $30^{\circ} \mathrm{S}$.

To investigate the degree of influence of mantle-related temperature variations in the shallow thermal field, we compared our results to a steady-state conductive model with a simplified lower boundary condition derived from a constant geothermal gradient of $5^{\circ} \mathrm{C} \mathrm{km}^{-1}$, which represents an average value for subduction zones (Syracuse et al., 2010; Fig. S11 in the supporting information). This allowed us to evaluate variations in the shallow thermal field in the case of neglecting deep-seated lateral thermal heterogeneities. At depth, there is no pronounced thermal contrast between the foreland of the flat and steep subduction segments, indicating that below $50 \mathrm{~km}$ bmsl, the main causative factors of the thermal heterogeneity of 
the foreland are the mantle heat input and the cooling effect of the slab. On the other hand, the model with a simplified boundary condition shows a more pronounced mismatch with the thermal observations (for instance, modeled temperatures are $5^{\circ} \mathrm{C}$ to $80^{\circ} \mathrm{C}$ colder than the borehole data) than the model with the lower boundary condition from the $\mathrm{v}_{\mathrm{s}}$-to-T conversion (Fig. S13 in the supporting information). This implies that the observed data is fitted not only with the lithospheric structure above the Moho, but also with laterally variable heat input from the slab and the lithospheric mantle.

There is an ongoing debate concerning the importance of radiogenic heat production for the thermal field and the long-term evolution of orogens where the radiogenic crust is thickened and where thermal effects of shortening, exhumation, and partial melting are observed (e.g., (Chen et al., 2019; Furlong \& Chapman, 2013; Gerbault et al., 2009; Jaupart et al., 2016; Mareschal \& Jaupart, 2013). Some authors suggest that radiogenic heating has less influence on the thermal field of the lithosphere in the overriding plate than either shear heating along the subduction interface (Penniston-Dorland et al., 2015) or episodes of magmatic underplating (Kaislaniemi et al., 2018). Yet other authors have focused on the general thermal evolution of subduction orogens and the metamorphic record, proposing that shallow asthenospheric convection is the main process responsible for elevated temperatures in the lithosphere, while disregarding any significant contribution from radiogenic heat production (Hyndman, 2005). In the latter study, for example, it is argued that thermal equilibrium is achieved only $50 \mathrm{Ma}$ after the main shortening phase, which contradicts the observation that peak metamorphism is synchronous with thickening (Collins, 2002; Thompson et al., 2001). However, the interpretations concerning thermal equilibrium conditions in an orogen have recently been disputed by geodynamic numerical modeling studies (Chen et al., 2019), which suggest that radioactive heating during crustal thickening is responsible for the observed marked temperature increase and subsequent partial melting within the mid-crust after $30 \mathrm{Ma}$ of shortening. The present-day SCA are within this time window after the main phase of shortening, which implies that crustal thickening that has taken place over more than $30 \mathrm{Ma}$ could indeed explain a significant part of excessive surface heat flow ( Hamza et al., 2008; Hamza et al., 2005; Hamza \& Muñoz, 1996) and the low seismic velocities observed across the orogen (Marot et al., 2014; Porter et al., 2012; L. Wagner et al., 2006; L. S. Wagner et al., 2005; Ward et al., 2013).

In Figure 13, we plot variations in predicted surface heat flow compared to available observations, together with the modeled thermal field and the configuration of the main 
lithospheric units along three representative E-W cross sections of the flat slab, the transition zone, and the steep-slab subduction segments. Predicted surface heat flow varies between the high surface heat-flow domains over both the orogen and the Payenia volcanic province (80$100 \mathrm{mWm}^{-2}$ ), and low heat-flow domains over the forearc, the remaining back-arc, and foreland regions (50-60 $\mathrm{mWm}^{-2}$ and $40-70 \mathrm{mWm}^{-2}$, respectively). These surface heat-flow variations correlate spatially with the thickness configuration of the sedimentary strata and upper crystalline crust, namely high heat flow in areas with thin low-conductive sedimentary rocks and thick radiogenic upper crust (i.e., Andean orogen, Payenia volcanic province), and low heat flow in regions with thick sedimentary cover and/or thin upper crust (foreland basins, forearc). An additional factor leading to low modeled heat flow in most of the forearc is the shallow depth of the cold oceanic plate. This factor does not play a role in the foreland, however; despite variable dip angles and temperature distributions along and across strike, no spatial correlation is observed between the thermal field at the subduction interface and the heat-flow patterns in the orogen and foreland.

The effects of the spatially variable heat input (either from the deep mantle or from radiogenic sources) and variable efficient heat conduction demonstrate that surface heat flow alone is a poor proxy for lower crustal or lithosphere thickness (Scheck-Wenderoth et al., 2014). Nevertheless, heat-flow estimates are often compared to seismic tomography, where $S$ wave attenuation (Qs) anomalies correlate to some extent with the thermal field (Artemieva, 2011). While areas of high heat flow are usually related to low Qs (high attenuation of the $\mathrm{v}_{\mathrm{s}}$ ), low heat flow is commonly associated with colder areas and hence high Qs (low attenuation of $\mathrm{v}_{\mathrm{s}}$ ). These spatial correlations were also identified across the SCA. Between $31.5^{\circ} \mathrm{S}$ and $33.5^{\circ} \mathrm{S}$, high surface heat flow predicted for the orogen coincides with low Qs (650-670; Deshayes, 2008). Accordingly, low predicted heat flow correlates with high Qs (800-1050) in the forearc and the foreland (Deshayes, 2008).

Discrepancies between observed surface heat flow (Hamza \& Muñoz, 1996; Lucazeau, 2019; Uyeda \& Watanabe, 1982) and the steady-state conductive model predictions in the proximity of active volcanic centers (Figs. 10b, 14) are related to unconsidered transient advective heat-transport processes, such as fluid migration or the existence of melts (e.g., Scheck-Wenderoth et al., 2014 and references therein). González-Vidal et al. (2018) demonstrated that such local effects of partial melting can be interpreted from negative $S$ wave anomalies imaged below the southern volcanic arc in the SCA area. 

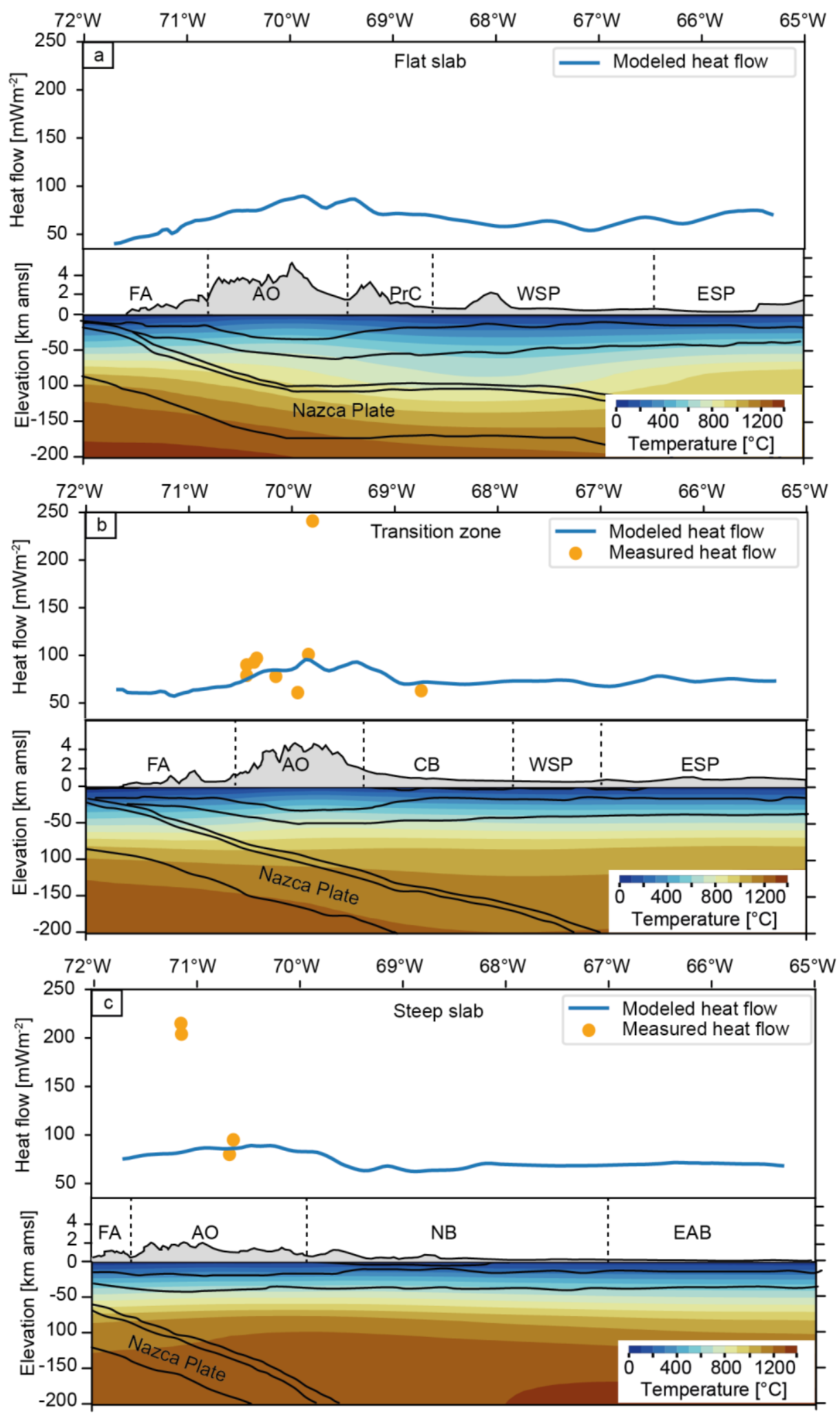

Figure 13. E-W cross sections showing modeled and measured surface heat flow (upper panel) and temperature distribution (lower panel) representative of the subduction segments of: (a) flat slab; (b) transition zone and (c) steep slab. For location of the profiles and abbreviations of the main morphotectonic provinces see Fig. 1. 


\subsection{Implications of the thermal field for the deformation modes in the SCA}

In view of the sensitivity of rock rheology to temperature, the lithological configuration from Rodriguez Piceda et al. (2020) and temperature variations derived in this study can be analyzed qualitatively in terms of their implications for the long-term strength of the lithosphere. In particular, areas that are colder and of more mafic lithology (i.e., the northern part of the forearc and foreland) are potentially stronger and can withstand higher levels of horizontal stresses before deforming viscously (Evgueni Burov, 2007) compared to areas that are warm and more felsic in composition (i.e., the orogen, the Payenia volcanic province, and the foreland at the latitudes of the transition to the steeper subduction segment). The general trends in the modeled temperature distribution of the SCA lithosphere are consistent with independent elasticthickness estimates derived from flexure analysis of the gravity field, which are an alternative, indirect proxy of lithospheric strength (Astort et al., 2019; Federico Ibarra \& Prezzi, 2019; Nacif et al., 2017; Sánchez et al., 2018; Tassara \& Yáñez, 2003). High and low elastic thickness are indicative of a strong and weak lithosphere, respectively (Burov \& Diament, 1995; Watts \& Burov, 2003). In the SCA, areas of high elastic thickness $(40-60 \mathrm{~km})$ correlate spatially with the modeled cold forearc and the northern part of the foreland. Conversely, areas of low elastic thickness $(<30 \mathrm{~km})$ correlate spatially with the modeled warm areas of the orogen, the Payenia volcanic province, and the foreland at the latitude of the transition to the steeper subduction segment.

The inferred trends in lithospheric strength related to variations in the upper-plate configuration have strong implications for the long-term deformation processes of the Central Andes (Barrionuevo et al., 2021; F. Ibarra et al., 2019; Liu, 2020; Meeßen, 2019). For example, Barrionuevo et al. (2021) argued on the basis of geodynamic numerical modeling that the vergence of the orogenic wedge at $33^{\circ}-36^{\circ} \mathrm{S}$ is mainly controlled by the E-W-oriented asymmetry of the lithosphere-asthenosphere boundary (LAB). The LAB configuration proposed by these authors agrees with our study, where a warmer lithospheric mantle, and thus shallower LAB, is encountered beneath the orogen compared to the adjacent foreland and forearc, i.e., areas where the mantle is colder and the LAB is located at greater depth. Furthermore, these authors suggest that heterogeneities in continental crustal composition could explain the observed N-S-oriented variations in the amounts of shortening and its spatial distribution within the orogen and the foreland between $33^{\circ}$ and $36^{\circ} \mathrm{S}$. In the north of their study region, the upper and lower crustal deformation maxima are aligned vertically with the strongest crustal thickening (pure-shear or coupled deformation mode), whereas to the south, upper 
crustal deformation is horizontally displaced with respect to the locus of lower crustal deformation (simple-shear or decoupled deformation mode). Accordingly, pure-shear deformation at $33^{\circ} \mathrm{S}$ would be mainly related to a more felsic and weaker crust; in contrast, simple-shear deformation at $36^{\circ} \mathrm{S}$ would result from a mafic and stronger crust (Barrionuevo et al., 2021). These results are compatible with gravity-constrained density distributions in the crust in the same region as proposed by Rodriguez Piceda et al. (2021) and with our results of a N-S-oriented decrease in crustal temperatures.

Furthermore, our results provide insights into the controversial debate over the governing mechanisms responsible for the formation of the spatially disparate thick-skinned deformation in the broken-foreland provinces of the Sierras Pampeanas between $27^{\circ}$ and $33^{\circ} \mathrm{S}$ and the Santa Bárbara System farther north. While some authors have proposed that the setting of the flat slab is responsible for the observed deformation in that area (Horton, 2018; Jordan et al., 1983; Martinod et al., 2020), others have argued that this style of deformation is controlled by the compressional reactivation of crustal heterogeneities such as Paleozoic sutures and associated deformation fabrics between crustal terranes or the inversion of Cretaceous normal faults prior to slab flattening (Hilley et al., 2005; Hongn et al., 2007; Hongn et al., 2010; Kley et al., 1999; Jonas Kley \& Monaldi, 2002; Meeßen, 2019; del Papa et al., 2013; Pearson et al., 2013; Ramos et al., 2002; Zapata et al., 2020). In the former case, the role of a flat slab is often assigned to a 'bulldozer keel,' which continuously transfers the tectonic stresses to the front of the flat segment where the slab is already steep (Gutscher et al., 2000; Horton, 2018; Jordan et al., 1983; Ramos \& Folguera, 2009). In this scenario, however, the role of the thermal and rheological fields of the overriding plate in the transmission and localization of stresses is not taken into account. More recently, Martinod et al. (2020) reinterpreted the role of the flat slab in the localization of deformation. Contrary to classical interpretations, these authors argue that, because the lithosphere above the flat slab is colder and stronger, most of it is subject to minor deformation. Therefore, deformation localizes where the slab starts to resume its steep subduction angle, triggered by slab-pull forces, rather than where the slab is already steep, as proposed by the 'bulldozer-keel' models (Gutscher et al., 2000; Horton, 2018; Jordan et al., 1983; Ramos \& Folguera, 2009).. The compositional and thermal characteristics of the lithosphere beneath the Sierras Pampeanas (i.e., mafic-dominated crust and cold lithosphere) derived from our results suggest that the lithosphere here is strong and may therefore inhibit the formation of crustal-scale faults, thus dismissing the 'bulldozer keel' effect as an efficient mechanism for propagating deformation. Instead, an additional process, either mechanical weakening within inherited basement heterogeneities and/or increased slab-pull where the slab 
resumes steep subduction, must be considered to explain the localization of deformation in the Sierras Pampeanas. The results of our study favor the hypothesis that either inherited heterogeneities and/or slab steepening controlled the geometry of faults that delimit the spatially isolated basement uplifts and the intervening sedimentary basins of the broken foreland between $27^{\circ} \mathrm{S}$ and $33^{\circ} \mathrm{S}$, rather than slab flattening. Opting for one or the other hypotheses mentioned above requires additional geodynamic modeling studies applied to the case of the SCA.

Addressing another aspect of the debate on the mechanisms that have sustained the flatsubduction setting over the last $\sim 20 \mathrm{Ma}$ in the SCA, it has been proposed on the basis of geodynamic numerical modeling that the strength of the overriding plate influences the subduction angle of the oceanic plate (Hu et al., 2016; Manea et al., 2012; Sharples et al., 2014). This has been suggested to be the case for the northern part of the SCA $\left(27^{\circ}-33^{\circ} \mathrm{S}\right)$, where the sub-horizontal slab segment underlies the thick and dense crust of the foreland of the South American plate (Rodriguez Piceda et al., 2021). Interestingly, the cold temperatures modeled for this area in our study exhibit two effects that might also favor slab shallowing: (i) cooling of the subduction interface that enhances the coupling between the continental and oceanic plates; and (ii) efficient E-W stress transmission along the cold and strong overriding plate, which forces the trench to retreat. In this context, there is a positive feedback between the cold lithosphere in the northern foreland and the flat-subduction setting: the shallow slab, together with a thin radiogenic crust, would cause low temperatures in the lithosphere in this domain, thereby strengthening the overriding plate, which in turn would promote slab shallowing.

\section{Conclusions}

By means of conversion of $S$ wave seismic tomography to temperatures and steady-state conductive numerical modeling, we derived the 3D lithospheric-scale temperature distribution of the southern Central Andes and adjacent forearc and foreland regions, and conclude the following:

1. Distinct controlling factors of the thermal field are dominant at different depths. At shallow depth $(<50 \mathrm{~km} \mathrm{bmsl})$, the thermal contrast between the warm orogen and the relatively cold areas of the forearc and foreland is modulated by the thickness of the upper radiogenic continental crystalline crust, which generates lateral changes of heat production. In the uppermost levels $(<5 \mathrm{~km})$, the effect of the sediment thickness is superimposed, leading to depocenters of the foreland basins being warmer than the edges due to thermal blanketing. The cool oceanic slab outweighs the heating effect of the continental crust in regions with relatively shallow slab depth $(<85 \mathrm{~km} \mathrm{bmsl})$ and 
where the upper continental crystalline crust is thin. This occurs in the forearc and in most of the northern part of the foreland $\left(29^{\circ}-33^{\circ} S\right)$ where the slab flattens. At depths $>50 \mathrm{~km} \mathrm{bmsl}$, the spatial correlation between crustal features and thermal heterogeneities is insignificant, and the main controlling factors become the mantle heat flow and the effect of the cold slab. However, down to $100 \mathrm{~km}$ bmsl, temperatures are additionally affected by the radiogenic contribution of the upper continental crystalline crust in the northern part of the orogen where this unit has a significant thickness $(>30$ $\mathrm{km})$.

There exists a strong contrast in surface heat flow between the warm orogen (80-105 $\mathrm{mWm}^{-2}$ ) and the relatively cold forearc and foreland areas $\left(40-75 \mathrm{mWm}^{-2}\right)$. These variations in heat flow are primarily controlled by the thickness configuration of the uppermost layers (sediments and upper crystalline crust). The shallow cold slab affects the pattern of surface heat flow beneath the forearc.

2. The modeled temperature configuration has implications for the rheology and, therefore, deformation patterns of the SCA. A cold, mafic, thick, and therefore potentially strong lithosphere beneath the broken foreland of the Sierras Pampeanas is prone to deformation processes that are controlled by inherited heterogeneities in the upper plate or by slab-pull, where the oceanic plate resumes steep subduction. In addition, such a lithospheric configuration may favor the coupling between the subducting and overriding plates, potentially contributing to a flat-subduction setting.

3. Sensitivity analysis of the $\mathrm{v}_{\mathrm{s}}$-to-T conversion shows that, at depths $<100 \mathrm{~km}$, mantle composition has the strongest effect on the $\mathrm{v}_{\mathrm{s}}$-to-T conversion for $\mathrm{v}_{\mathrm{s}}$ larger than $4.6 \mathrm{~km}$ $\mathrm{s}^{-1}$, as is the case for the flat-slab segment. Nevertheless, compositional variations within the range of uncertainty do not affect the main temperature and heat-flow trends found in this study.

\section{Acknowledgments}

This research was funded by the Deutsche Forschungsgemeinschaft (DFG) and the Federal State of Brandenburg under the auspices of the International Research Training Group IGK2018 "SuRfAce processes, TEctonics and Georesources: The Andean foreland basin of Argentina" (STRATEGy), DFG grant STR 373/34-1 to M. Strecker and M. Scheck-Wenderoth. We are grateful to Marcelo Assumpção and Mei Feng for providing the seismic tomography for the 
conversion to temperatures, and to Corinna Kallich for the assistance on the figures. The color scales used in Figs. 2-4,6-14 were taken from Crameri (2018), Scientific colour-maps (DOI:10.5281/zenodo.1243862). Data visualization was carried out with ParaView software (https://paraview.org). Figures were produced with Python. The authors declare that they have no conflict of interest.

\section{Open Research}

The 3D thermal model presented in this publication is accessible at Rodriguez Piceda et al. (2021) via GFZ Data Services.

\section{References}

Allmendinger, Richard W., Jordan, T. E., Kay, S. M., \& Isacks, B. L. (1997). THE EVOLUTION OF THE ALTIPLANO-PUNA PLATEAU OF THE CENTRAL ANDES. Annual Review of Earth and Planetary Sciences, 25(1), 139-174. https://doi.org/10.1146/annurev.earth.25.1.139

Allmendinger, R.W., \& Gubbels, T. (1996). Pure and simple shear plateau uplift, AltiplanoPuna, Argentina and Bolivia. Tectonophysics, 259(1-3), 1-13. https://doi.org/10.1016/00401951(96)00024-8

Alvarado, P., Beck, S., \& Zandt, G. (2007). Crustal structure of the south-central Andes Cordillera and backarc region from regional waveform modelling. Geophysical Journal International, 170(2), 858-875. https://doi.org/10.1111/j.1365-246X.2007.03452.x

Alvarado, Patricia, Pardo, M., Gilbert, H., Miranda, S., Anderson, M., Saez, M., \& Beck, S. (2009). Flat-slab subduction and crustal models for the seismically active Sierras Pampeanas region of Argentina. In S. M. Kay, V. A. Ramos, \& W. R. Dickinson, Backbone of the Americas: Shallow Subduction, Plateau Uplift, and Ridge and Terrane Collision. Geological Society of America. https://doi.org/10.1130/2009.1204(12)

Amante, C., \& Eakins, B. (2009). ETOPO1 1 Arc-Minute Global Relief Model: Procedures, Data Sources and Analysis (NOAA Technical Memorandum NESDIS NGDC-24). National Geophysical Data Center, NOAA. Retrieved from doi:10.7289/V5C8276M

Ammirati, J.-B., Alvarado, P., Perarnau, M., Saez, M., \& Monsalvo, G. (2013). Crustal structure of the Central Precordillera of San Juan, Argentina $\left(31^{\circ} \mathrm{S}\right)$ using teleseismic receiver functions. Journal of South American Earth Sciences, 46, 100-109.

https://doi.org/10.1016/j.jsames.2013.05.007

Ammirati, J.-B., Alvarado, P., \& Beck, S. (2015). A lithospheric velocity model for the flat slab region of Argentina from joint inversion of Rayleigh wave phase velocity dispersion and teleseismic receiver functions. Geophysical Journal International, 202(1), 224-241.

https://doi.org/10.1093/gji/ggv140 
Ammirati, J.-B., Venerdini, A., Alcacer, J. M., Alvarado, P., Miranda, S., \& Gilbert, H. (2018). New insights on regional tectonics and basement composition beneath the eastern Sierras Pampeanas (Argentine back-arc region) from seismological and gravity data. Tectonophysics, 740-741, 42-52. https://doi.org/10.1016/j.tecto.2018.05.015

An, M., Wiens, D. A., Zhao, Y., Feng, M., Nyblade, A., Kanao, M., et al. (2015).

Temperature, lithosphere-asthenosphere boundary, and heat flux beneath the Antarctic Plate inferred from seismic velocities. Journal of Geophysical Research: Solid Earth, 120(12), 8720-8742. https://doi.org/10.1002/2015JB011917

Anikiev, D., Cacace, M., Bott, J., Gomez Dacal, M. L., \& Scheck-Wenderoth, M. (2020). Influence of Lithosphere Rheology on Seismicity in an Intracontinental Rift: The Case of the Rhine Graben. Frontiers in Earth Science, 8, 492. https://doi.org/10.3389/feart.2020.592561

Araneda, M., Asch, G., Bataille, K., Bohm, M., Bruhn, C., Giese, P., et al. (2003). A crustal model along $39^{\circ} \mathrm{S}$ from a seismic refraction profile-ISSA 2000. Revista Geológica de Chile, 30(1), 83-101. http://dx.doi.org/10.4067/S0716-02082003000100006

Artemieva, I. (2011). Lithosphere: an interdisciplinary approach. Cambridge University Press.

Assumpção, M., Feng, M., Tassara, A., \& Julià, J. (2013). Models of crustal thickness for South America from seismic refraction, receiver functions and surface wave tomography. Tectonophysics, 609, 82-96. https://doi.org/10.1016/j.tecto.2012.11.014

Astini, R., Benedetto, J., \& Vaccari, N. (1995). The early Paleozoic evolution of the Argentine Precordillera as a Laurentian rifted, drifted, and collided terrane: A geodynamic model. Geological Society of America Bulletin, 107(3), 253-273. https://doi.org/10.1130/0016-7606(1995)107<0253:TEPEOT>2.3.CO;2

Astort, A., Colavitto, B., Sagripanti, L., García, H., Echaurren, A., Soler, S., et al. (2019). Crustal and Mantle Structure Beneath the Southern Payenia Volcanic Province Using Gravity and Magnetic Data. Tectonics, 38(1), 144-158. https://doi.org/10.1029/2017TC004806

Azcuy, C., \& Caminos, R. (1987). El Sistema Carbonifero en la Republica Argentina. Diastrofismo. In El sistema carbonífero en la República Argentina (pp. 239-251). Córdoba, Argentina: Academia Nacional de Ciencias.

Barazangi, M., \& Isacks, B. L. (1976). Spatial distribution of earthquakes and subduction of the Nazca plate beneath South America. Geology, 4(11), 686-692.

Barrionuevo, M., Liu, S., Mescua, J., Yagupsky, D., Quinteros, J., Giambiagi, L., et al. (2021). The influence of variations in crustal composition and lithospheric strength on the evolution of deformation processes in the southern Central Andes: Insights from geodynamic models. International Journal of Earth Sciences. https://doi.org/10.1007/s00531-021-01982-5

Berckhemer, H., Kampfmann, W., Aulbach, E., \& Schmeling, H. (1982). Shear modulus and $\mathrm{Q}$ of forsterite and dunite near partial melting from forced-oscillation experiments. Physics of the Earth and Planetary Interiors, 29(1), 30-41. https://doi.org/10.1016/00319201(82)90135-2 
Boonma, K., Kumar, A., Garcia-Castellanos, D., Jiménez-Munt, I., \& Fernández, M. (2019). Lithospheric mantle buoyancy: the role of tectonic convergence and mantle composition. Scientific Reports, 9(1), 17953. https://doi.org/10.1038/s41598-019-54374-w

Boyce, D., Charrier, R., \& Farías, M. (2020). The First Andean Compressive Tectonic Phase: Sedimentologic and Structural Analysis of Mid-Cretaceous Deposits in the Coastal Cordillera, Central Chile (3250'S). Tectonics, 39(2). https://doi.org/10.1029/2019TC005825

Brocher, T. M. (2005). Empirical Relations between Elastic Wavespeeds and Density in the Earth's Crust. Bulletin of the Seismological Society of America, 95(6), 2081-2092. https://doi.org/10.1785/0120050077

Burov, E., \& Diament, M. (1995). The effective elastic thickness (Te) of continental lithosphere: What does it really mean? Journal of Geophysical Research, 100, 3905-3927. https://doi.org/10.1029/94JB02770

Burov, Evgueni. (2007). Coupled lithosphere-surface processes in collision context. In Thrust Belts and Foreland Basins (pp. 3-40). Springer.

Cacace, M., \& Jacquey, A. B. (2017). Flexible parallel implicit modelling of coupled thermal-hydraulic-mechanical processes in fractured rocks. Solid Earth, 8(5), 921-941. https://doi.org/10.5194/se-8-921-2017

Cahill, T., \& Isacks, B. L. (1992). Seismicity and shape of the subducted Nazca Plate. Journal of Geophysical Research, 97(B12), 17503. https://doi.org/10.1029/92JB00493

Calixto, F. J., Sandvol, E., Kay, S., Mulcahy, P., Heit, B., Yuan, X., et al. (2013). Velocity structure beneath the southern Puna plateau: Evidence for delamination: Velocity Structure in The Southern Puna. Geochemistry, Geophysics, Geosystems, 14(10), 4292-4305. https://doi.org/10.1002/ggge.20266

Cammarano, F., Goes, S., Vacher, P., \& Giardini, D. (2003). Inferring upper-mantle temperatures from seismic velocities. Physics of the Earth and Planetary Interiors, 138(3), 197-222. https://doi.org/10.1016/S0031-9201(03)00156-0

Čermák, V., \& Rybach, L. (1982). Thermal conductivity and specific heat of minerals and rocks. Landolt-Börnstein: Numerical Data and Functional Relationships in Science and Technology, New Series, Group V (Geophysics and Space Research), Volume Ia,(Physical Properties of Rocks), Edited by G. Angenheister, Springer, Berlin-Heidelberg, 305-343.

Chen, L., Song, X., Gerya, T. V., Xu, T., \& Chen, Y. (2019). Crustal melting beneath orogenic plateaus: Insights from 3-D thermo-mechanical modeling. Tectonophysics, 761, 115. https://doi.org/10.1016/j.tecto.2019.03.014

Christensen, N. I., \& Mooney, W. D. (1995). Seismic velocity structure and composition of the continental crust: A global view. Journal of Geophysical Research: Solid Earth, 100(B6), 9761-9788. https://doi.org/10.1029/95JB00259

Č́ížková, H., \& Bina, C. R. (2013). Effects of mantle and subduction-interface rheologies on slab stagnation and trench rollback. Earth and Planetary Science Letters, 379, 95-103. https://doi.org/10.1016/j.epsl.2013.08.011 
Collins, W. J. (2002). Hot orogens, tectonic switching, and creation of continental crust. Geology, 30(6), 535-538. https://doi.org/10.1130/0091-

7613(2002)030<0535:HOTSAC>2.0.CO;2

Collo, G., Ezpeleta, M., Dávila, F. M., Giménez, M., Soler, S., Martina, F., et al. (2018). Basin Thermal Structure in the Chilean-Pampean Flat Subduction Zone. In The Evolution of the Chilean-Argentinean Andes (pp. 537-564). Springer.

Conceição, R. V., Mallmann, G., Koester, E., Schilling, M., Bertotto, G. W., \& RodriguezVargas, A. (2005). Andean subduction-related mantle xenoliths: Isotopic evidence of $\mathrm{Sr}-\mathrm{Nd}$ decoupling during metasomatism. Lithos, 82(3-4), 273-287.

https://doi.org/10.1016/j.lithos.2004.09.022

Contreras-Reyes, E., Grevemeyer, I., Flueh, E. R., \& Reichert, C. (2008). Upper lithospheric structure of the subduction zone offshore of southern Arauco peninsula, Chile, at $\sim 38^{\circ} \mathrm{S}$. Journal of Geophysical Research, 113(B7), B07303. https://doi.org/10.1029/2007JB005569

Copernicus Climate Change Service (C3S). (2019). ERA5-Land monthly averaged data from 1981 to present. Retrieved from 10.24381/cds.68d2bb3

Deschamps, F., Trampert, J., \& Snieder, R. (2002). Anomalies of temperature and iron in the uppermost mantle inferred from gravity data and tomographic models. Physics of the Earth and Planetary Interiors, 129(3), 245-264. https://doi.org/10.1016/S0031-9201(01)00294-1

Deshayes, P. (2008, November). Velocity and attenuation tomography of the subduction zone in central Chile-western Argentina $\left(29^{\circ} \mathrm{S}-34^{\circ} \mathrm{S}\right)$ from local seismic data: contribution to the mineralogical composition study. (Theses). Université Nice Sophia Antipolis. Retrieved from https://tel.archives-ouvertes.fr/tel-00360063

England, P. (2018). On Shear Stresses, Temperatures, and the Maximum Magnitudes of Earthquakes at Convergent Plate Boundaries. Journal of Geophysical Research: Solid Earth, 123(8), 7165-7202. https://doi.org/10.1029/2018JB015907

Feng, M., van der Lee, S., \& Assumpção, M. (2007). Upper mantle structure of South America from joint inversion of waveforms and fundamental mode group velocities of Rayleigh waves. Journal of Geophysical Research: Solid Earth, 112(B4). https://doi.org/10.1029/2006JB004449

Fennell, L. M., Folguera, A., Naipauer, M., Gianni, G., Rojas Vera, E. A., Bottesi, G., \& Ramos, V. A. (2015). Cretaceous deformation of the southern Central Andes: synorogenic growth strata in the Neuquén Group ( $\left.35^{\circ} 30^{\prime}-37^{\circ} \mathrm{S}\right)$. Basin Research, 51-72. https://doi.org/10.1111/bre.12135

Freymark, J., Sippel, J., Scheck-Wenderoth, M., Bär, K., Stiller, M., Fritsche, J.-G., \& Kracht, M. (2017). The deep thermal field of the Upper Rhine Graben. Tectonophysics, 694, 114-129. https://doi.org/10.1016/j.tecto.2016.11.013

Furlong, K. P., \& Chapman, D. S. (2013). Heat Flow, Heat Generation, and the Thermal State of the Lithosphere. Annual Review of Earth and Planetary Sciences, 41(1), 385-410. https://doi.org/10.1146/annurev.earth.031208.100051

Gao, Y., Tilmann, F., van Herwaarden, D., Thrastarson, S., Fichtner, A., Heit, B., et al. (2021). Full Waveform Inversion beneath the Central Andes: Insight into the dehydration of 
the Nazca slab and delamination of the back-arc lithosphere. Journal of Geophysical Research: Solid Earth. https://doi.org/10.1029/2021JB021984

Gerbault, M., Cembrano, J., Mpodozis, C., Farias, M., \& Pardo, M. (2009). Continental margin deformation along the Andean subduction zone: Thermo-mechanical models. Physics of the Earth and Planetary Interiors, 177(3), 180-205.

https://doi.org/10.1016/j.pepi.2009.09.001

Giambiagi, L. B., Ramos, V. A., Godoy, E., Alvarez, P. P., \& Orts, S. (2003). Cenozoic deformation and tectonic style of the Andes, between $33^{\circ}$ and $34^{\circ}$ south latitude. Tectonics, 22(4), n/a-n/a. https://doi.org/10.1029/2001TC001354

Gilbert, H., Beck, S., \& Zandt, G. (2006). Lithospheric and upper mantle structure of central Chile and Argentina. Geophysical Journal International, 165(1), 383-398.

https://doi.org/10.1111/j.1365-246X.2006.02867.x

Goes, S, Govers, R., \& Vacher, and P. (2000). Shallow mantle temperatures under Europe from P and S wave tomography. Journal of Geophysical Research: Solid Earth, 105(B5), 11153-11169. https://doi.org/10.1029/1999JB900300

Goes, Saskia, Hasterok, D., Schutt, D. L., \& Klöcking, M. (2020). Continental lithospheric temperatures: A review. Physics of the Earth and Planetary Interiors, 306, 106509. https://doi.org/10.1016/j.pepi.2020.106509

Gutscher, M., Spakman, W., Bijwaard, H., \& Engdahl, E. R. (2000). Geodynamics of flat subduction: Seismicity and tomographic constraints from the Andean margin. Tectonics, 19(5), 814-833.

Gutscher, M.-A. (2002). Andean subduction styles and their effect on thermal structure and interplate coupling. Journal of South American Earth Sciences, 15(1), 3-10.

https://doi.org/10.1016/S0895-9811(02)00002-0

Hamza, V. M., Cardoso, R. R., \& Ponte Neto, C. F. (2008). Spherical harmonic analysis of earth's conductive heat flow. International Journal of Earth Sciences, 97(2), 205-226. https://doi.org/10.1007/s00531-007-0254-3

Hamza, Valiya M., \& Muñoz, M. (1996). Heat flow map of South America. Geothermics, 25(6), 599-646. https://doi.org/10.1016/S0375-6505(96)00025-9

Hamza, Valiya M., Dias, F. J. S. S., Gomes, A. J. L., \& Terceros, Z. G. D. (2005). Numerical and functional representations of regional heat flow in South America. Physics of the Earth and Planetary Interiors, 152(4), 223-256. https://doi.org/10.1016/j.pepi.2005.04.009

Hasterok, D., \& Chapman, D. (2011). Heat production and geotherms for the continental lithosphere. Earth and Planetary Science Letters, 307(1-2), 59-70.

https://doi.org/10.1016/j.epsl.2011.04.034

Hayes, G. P., Moore, G. L., Portner, D. E., Hearne, M., Flamme, H., Furtney, M., \& Smoczyk, G. M. (2018). Slab2, a comprehensive subduction zone geometry model. Science, 362(6410), 58. https://doi.org/10.1126/science.aat4723

He, L., Hu, S., Huang, S., Yang, W., Wang, J., Yuan, Y., \& Yang, S. (2008). Heat flow study at the Chinese Continental Scientific Drilling site: Borehole temperature, thermal 
conductivity, and radiogenic heat production. Journal of Geophysical Research, 113(B2), B02404. https://doi.org/10.1029/2007JB004958

Heine, C. (2007). Formation and Evolution of intracontinental basins. University of Sidney, Sydney.

Henry, S. G., \& Pollack, H. N. (1988). Terrestrial heat flow above the Andean Subduction Zone in Bolivia and Peru. Journal of Geophysical Research: Solid Earth, 93(B12), 1515315162. https://doi.org/10.1029/JB093iB12p15153

Hilley, G. E., Blisniuk, P. M., \& Strecker, M. R. (2005). Mechanics and erosion of basementcored uplift provinces. Journal of Geophysical Research: Solid Earth, 110(B12). https://doi.org/10.1029/2005JB003704

Holt, A. F., \& Condit, C. B. (2021). Slab Temperature Evolution Over the Lifetime of a Subduction Zone. Geochemistry, Geophysics, Geosystems, 22(6).

https://doi.org/10.1029/2020GC009476

Hongn, F., Papa, C. del, Powell, J., Petrinovic, I., Mon, R., \& Deraco, V. (2007). Middle Eocene deformation and sedimentation in the Puna-Eastern Cordillera transition $\left(23^{\circ}-26^{\circ} \mathrm{S}\right)$ : Control by preexisting heterogeneities on the pattern of initial Andean shortening. Geology, 35(3), 271-274. https://doi.org/10.1130/G23189A.1

Hongn, Fernando, Mon, R., Petrinovic, I., del Papa, C., \& Powell, J. (2010). Inversión y reactivación tectónicas cretácico-cenozoicas en el noroeste argentino: influencia de las heterogeneidades del basamento Neoproterozoico-Paleozoico inferior. Revista de La Asociación Geológica Argentina, 66(1-2), 38-53.

Horton, B. K. (2018). Sedimentary record of Andean mountain building. Earth-Science Reviews, 178, 279-309. https://doi.org/10.1016/j.earscirev.2017.11.025

Hu, J., Liu, L., Hermosillo, A., \& Zhou, Q. (2016). Simulation of late Cenozoic South American flat-slab subduction using geodynamic models with data assimilation. Earth and Planetary Science Letters, 438, 1-13. https://doi.org/10.1016/j.epsl.2016.01.011

van Hunen, J., van den Berg, A. P., \& Vlaar, N. J. (2000). A thermo-mechanical model of horizontal subduction below an overriding plate. Earth and Planetary Science Letters, 182(2), 157-169. https://doi.org/10.1016/S0012-821X(00)00240-5

van Hunen, J., Van Den BERG, A. P., \& Vlaar, N. J. (2002). On the role of subducting oceanic plateaus in the development of shallow flat subduction. Tectonophysics, 352(3-4), $317-333$.

van Hunen, J., van den Berg, A. P., \& Vlaar, N. J. (2004). Various mechanisms to induce present-day shallow flat subduction and implications for the younger Earth: a numerical parameter study. Physics of the Earth and Planetary Interiors, 146(1), 179-194.

https://doi.org/10.1016/j.pepi.2003.07.027

Hyndman, R. D. (2005). Subduction zone backarcs, mobile belts, and orogenic heat. GSA TODAY, 7.

Ibarra, F., Liu, S., Meeßen, C., Prezzi, C. B., Bott, J., Scheck-Wenderoth, M., et al. (2019). 3D data-derived lithospheric structure of the Central Andes and its implications for 
deformation: Insights from gravity and geodynamic modelling. Tectonophysics, 766, 453468. https://doi.org/10.1016/j.tecto.2019.06.025

Ibarra, F., Prezzi, C. B., Bott, J., Scheck-Wenderoth, M., \& Strecker, M. R. (2021). Distribution of Temperature and Strength in the Central Andean Lithosphere and Its Relationship to Seismicity and Active Deformation. Journal of Geophysical Research: Solid Earth, 126(5). https://doi.org/10.1029/2020JB021231

Ibarra, Federico, \& Prezzi, C. B. (2019). The thermo-mechanical state of the Andes in the Altiplano-Puna region: insights from Curie isotherm and effective elastic thickness determination. Revista de La Asociación Geológica Argentina, 76(4), 352-362.

Ince, E. S., Barthelmes, F., Reißland, S., Elger, K., Förste, C., Flechtner, F., \& Schuh, H. (2019). ICGEM - 15 years of successful collection and distribution of global gravitational models, associated services, and future plans. Earth System Science Data, 11(2), 647-674. https://doi.org/10.5194/essd-11-647-2019

Isacks, B. L. (1988). Uplift of the Central Andean Plateau and bending of the Bolivian Orocline. Journal of Geophysical Research: Solid Earth, 93(B4), 3211-3231. https://doi.org/10.1029/JB093iB04p03211

Jacquey, A. B., \& Cacace, M. (2017). GOLEM, a MOOSE-based application (Version v1.0). Zenodo. https://doi.org/10.5281/zenodo.999401

Jalowitzki, T. L. R., Conceição, R. V., Orihashi, Y., Bertotto, G. W., Nakai, S., \& Schilling, M. E. (2010). Evolução geoquímica de peridotitos e piroxenitos do Manto Litosférico Subcontinental do vulcão Agua Poca, Terreno Cuyania, Argentina. Pesquisas em Geociências, 37(2), 143. https://doi.org/10.22456/1807-9806.22656

Jaupart, C., Mareschal, J.-C., \& Iarotsky, L. (2016). Radiogenic heat production in the continental crust. Lithos, 262, 398-427. https://doi.org/10.1016/j.lithos.2016.07.017

Jones, R. E., De Hoog, J. C., Kirstein, L. A., Kasemann, S. A., Hinton, R., Elliott, T., \& Litvak, V. D. (2014). Temporal variations in the influence of the subducting slab on Central Andean arc magmas: Evidence from boron isotope systematics. Earth and Planetary Science Letters, 408, 390-401. https://doi.org/10.1016/j.epsl.2014.10.004

Jones, R. E., Kirstein, L. A., Kasemann, S. A., Dhuime, B., Elliott, T., Litvak, V. D., et al. (2015). Geodynamic controls on the contamination of Cenozoic arc magmas in the southern Central Andes: Insights from the $\mathrm{O}$ and Hf isotopic composition of zircon. Geochimica et Cosmochimica Acta, 164, 386-402.

Jones, R. E., Kirstein, L. A., Kasemann, S. A., Litvak, V. D., Poma, S., Alonso, R. N., \& Hinton, R. (2016). The role of changing geodynamics in the progressive contamination of Late Cretaceous to Late Miocene arc magmas in the southern Central Andes. Lithos, 262, 169-191. https://doi.org/10.1016/j.lithos.2016.07.002

Jordan, T. E., Isacks, B. L., Allmendinger, R. W., Brewer, J. A., Ramos, V. A., \& Ando, C. J. (1983). Andean tectonics related to geometry of subducted Nazca plate. Geological Society of America Bulletin, 94(3), 341-361.

Kaban, M. K., Tesauro, M., Mooney, W. D., \& Cloetingh, S. A. P. L. (2014). Density, temperature, and composition of the North American lithosphere-New insights from a joint 
analysis of seismic, gravity, and mineral physics data: 1 . Density structure of the crust and upper mantle. Geochemistry, Geophysics, Geosystems, 15(12), 4781-4807. https://doi.org/10.1002/2014GC005483

Kaislaniemi, L., Hunen, J., \& Bouilhol, P. (2018). Lithosphere Destabilization by Melt Weakening and Crust-Mantle Interactions: Implications for Generation of Granite-Migmatite Belts, 15 .

Kay, S. M., \& Mpodozis, C. (2002). Magmatism as a probe to the Neogene shallowing of the Nazca plate beneath the modern Chilean ${ }^{-}$at-slab. Journal of South American Earth Sciences, 19 .

Kay, S. M., Coira, B., \& Viramonte, J. (1994). Young mafic back arc volcanic rocks as indicators of continental lithospheric delamination beneath the Argentine Puna Plateau, central Andes. Journal of Geophysical Research: Solid Earth, 99(B12), 24323-24339. https://doi.org/10.1029/94JB00896

Kay, S. M., Burns, W. M., Copeland, P., \& Mancilla, O. (2006). Upper Cretaceous to Holocene magmatism and evidence for transient Miocene shallowing of the Andean subduction zone under the northern Neuquén Basin. In S. M. Kay \& V. A. Ramos (Eds.), Evolution of an Andean Margin: A Tectonic and Magmatic View from the Andes to the

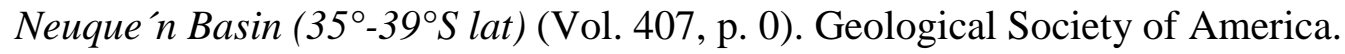
https://doi.org/10.1130/2006.2407(02)

van Keken, P. E., Wada, I., Sime, N., \& Abers, G. A. (2019). Thermal Structure of the Forearc in Subduction Zones: A Comparison of Methodologies. Geochemistry, Geophysics, Geosystems, 20(7), 3268-3288. https://doi.org/10.1029/2019GC008334

Kennett, B. L. N., Engdahl, E. R., \& Buland, R. (1995). Constraints on seismic velocities in the Earth from traveltimes. Geophysical Journal International, 122(1), 108-124. https://doi.org/10.1111/j.1365-246X.1995.tb03540.x

Kley, J., Monaldi, C. R., \& Salfity, J. A. (1999). Along-strike segmentation of the Andean foreland: causes and consequences. Tectonophysics, 301(1), 75-94.

https://doi.org/10.1016/S0040-1951(98)90223-2

Kley, Jonas, \& Monaldi, C. R. (2002). Tectonic inversion in the Santa Barbara System of the central Andean foreland thrust belt, northwestern Argentina. Tectonics, 21(6), 11-1-11-18. https://doi.org/10.1029/2002TC902003

Kusznir, N. J., \& Park, R. G. (1984). Intraplate lithosphere deformation and the strength of the lithosphere. Geophysical Journal International, 79(2), 513-538.

https://doi.org/10.1111/j.1365-246X.1984.tb02238.x

Leng, W., \& Mao, W. (2015). Geodynamic modeling of thermal structure of subduction zones. Science China Earth Sciences, 58(7), 1070-1083. https://doi.org/10.1007/s11430-0155107-5

Liu, S. (2020). Controls of foreland-deformation patterns in the orogen-foreland shortening system. Retrieved from https://publishup.uni-potsdam.de/frontdoor/index/index/docId/44573 
Llambias, E. J., \& Sato, A. M. (1990). El Batolito de Colangüil (29-31 S) cordillera frontal de Argentina: estructura y marco tectonico. Andean Geology, 17(1), 89-108.

http://dx.doi.org/10.5027/andgeoV17n1-a04

LLambias, E. J., Kleiman, L. E., \& Salvarredi, J. A. (1993). El magmatismo gondwánico (pp. 53-64). Presented at the Geología y Recursos Naturales de Mendoza (Ramos, V.; editor).

Congreso Geológico Argentino.

Lucazeau, F. (2019). Analysis and Mapping of an Updated Terrestrial Heat Flow Data Set. Geochemistry, Geophysics, Geosystems, 20(8), 4001-4024.

https://doi.org/10.1029/2019GC008389

Lucazeau, F., \& Le Douaran, S. (1985). The blanketing effect of sediments in basins formed by extension: a numerical model. Application to the Gulf of Lion and Viking graben. Earth and Planetary Science Letters, 74(1), 92-102. https://doi.org/10.1016/0012-821X(85)90169-4

Maaløe, S., \& Aoki, K. (1977). The major element composition of the upper mantle estimated from the composition of lherzolites. Contributions to Mineralogy and Petrology, 63(2), 161173. https://doi.org/10.1007/BF00398777

Maloney, K. T., Clarke, G. L., Klepeis, K. A., \& Quevedo, L. (2013). The Late Jurassic to present evolution of the Andean margin: Drivers and the geological record: evolution of the Andean margin. Tectonics, 32(5), 1049-1065. https://doi.org/10.1002/tect.20067

Manea, V.C., Manea, M., Ferrari, L., Orozco-Esquivel, T., Valenzuela, R. W., Husker, A., \& Kostoglodov, V. (2017). A review of the geodynamic evolution of flat slab subduction in Mexico, Peru, and Chile. Tectonophysics, 695, 27-52.

https://doi.org/10.1016/j.tecto.2016.11.037

Manea, Vlad C, \& Manea, M. (2011). Flat-slab thermal structure and evolution beneath central Mexico. Pure and Applied Geophysics, 168(8-9), 1475-1487.

Manea, Vlad C., Pérez-Gussinyé, M., \& Manea, M. (2012). Chilean flat slab subduction controlled by overriding plate thickness and trench rollback. Geology, 40(1), 35-38.

https://doi.org/10.1130/G32543.1

Mareschal, J.-C., \& Jaupart, C. (2013). Radiogenic heat production, thermal regime and evolution of continental crust. Moho: 100 Years after Andrija Mohorovicic, 609, 524-534. https://doi.org/10.1016/j.tecto.2012.12.001

Marot, M., Monfret, T., Gerbault, M., Nolet, G., Ranalli, G., \& Pardo, M. (2014). Flat versus normal subduction zones: a comparison based on 3-D regional traveltime tomography and petrological modelling of central Chile and western Argentina $\left(29^{\circ}-35^{\circ} \mathrm{S}\right)$. Geophysical Journal International, 199(3), 1633-1654. https://doi.org/10.1093/gji/ggu355

Martinod, J., Gérault, M., Husson, L., \& Regard, V. (2020). Widening of the Andes: An interplay between subduction dynamics and crustal wedge tectonics. Earth-Science Reviews, 204, 103170. https://doi.org/10.1016/j.earscirev.2020.103170

McKenzie, D., Jackson, J., \& Priestley, K. (2005). Thermal structure of oceanic and continental lithosphere. Earth and Planetary Science Letters, 233(3-4), 337-349.

https://doi.org/10.1016/j.eps1.2005.02.005 
Meeßen. (2017). VelocityConversion. V. v1.0.1. GFZ Data Services. Retrieved from http://doi.org/10.5880/GFZ.6.1.2017.001

Meeßen, C. (2019). The thermal and rheological state of the Northern Argentinian foreland basins (doctoralthesis). Universität Potsdam. https://doi.org/10.25932/publishup-43994

Meeßen, C. (2020). VeloDT v1.2 (Version v1.2). Zenodo.

https://doi.org/10.5281/zenodo.3895784

Mescua, J. F., Giambiagi, L., Barrionuevo, M., Tassara, A., Mardonez, D., Mazzitelli, M., \& Lossada, A. (2016). Basement composition and basin geometry controls on upper-crustal deformation in the Southern Central Andes (30-36 ${ }^{\circ}$ S). Geological Magazine, 153(5-6), 945961. https://doi.org/10.1017/S0016756816000364

Mpodozis, C., \& Kay, S. M. (1990). Provincias magmáticas ácidas y evolución tectónica de Gondwana: Andes chilenos (28-31 S). Andean Geology, 17(2), 153-180.

http://dx.doi.org/10.5027/andgeoV17n2-a03

Nacif, S., Lupari, M., Triep, E. G., Nacif, A., Álvarez, O., Folguera, A., \& Gímenez, M. (2017). Change in the pattern of crustal seismicity at the Southern Central Andes from a local seismic network. Tectonophysics, 708, 56-69. https://doi.org/10.1016/j.tecto.2017.04.012

Oncken, O., Chong, G., Gerhard, F., Giese, P., Götze, H.-J., Ramos, V. A., et al. (2006). The Andes: Active Subduction Orogeny (1st ed.). Heidelberg: Springer-Verlag Berlin Heidelberg. Retrieved from https://www.springer.com/gp/book/9783540243298

del Papa, C., Hongn, F., Powell, J., Payrola, P., Do Campo, M., Strecker, M. R., et al. (2013). Middle Eocene-Oligocene broken-foreland evolution in the Andean Calchaqui Valley, NW Argentina: insights from stratigraphic, structural and provenance studies. Basin Research, 25(5), 574-593. https://doi.org/10.1111/bre.12018

Peacock, S. M. (2020). Advances in the thermal and petrologic modeling of subduction zones. Geosphere, 16(4), 936-952. https://doi.org/10.1130/GES02213.1

Pearson, D. M., Kapp, P., DeCelles, P. G., Reiners, P. W., Gehrels, G. E., Ducea, M. N., \& Pullen, A. (2013). Influence of pre-Andean crustal structure on Cenozoic thrust belt kinematics and shortening magnitude: Northwestern Argentina. Geosphere, 9(6), 1766-1782. https://doi.org/10.1130/GES00923.1

Penniston-Dorland, S. C., Kohn, M. J., \& Manning, C. E. (2015). The global range of subduction zone thermal structures from exhumed blueschists and eclogites: Rocks are hotter than models. Earth and Planetary Science Letters, 428, 243-254.

https://doi.org/10.1016/j.eps1.2015.07.031

Pesicek, J. D., Engdahl, E. R., Thurber, C. H., DeShon, H. R., \& Lange, D. (2012). Mantle subducting slab structure in the region of the 2010 M8.8 Maule earthquake (30-40 $\left.{ }^{\circ} \mathrm{S}\right)$, Chile: Mantle subducting slab structure in Chile. Geophysical Journal International, 191(1), 317324. https://doi.org/10.1111/j.1365-246X.2012.05624.x

Porter, R., Gilbert, H., Zandt, G., Beck, S., Warren, L., Calkins, J., et al. (2012). Shear wave velocities in the Pampean flat-slab region from Rayleigh wave tomography: Implications for slab and upper mantle hydration: PAMPEAN FLAT SLAB SHEAR VELOCITIES. Journal 
of Geophysical Research: Solid Earth, 117(B11), n/a-n/a.

https://doi.org/10.1029/2012JB009350

Prezzi, C., Iglesia Llanos, M. P., Götze, H.-J., \& Schmidt, S. (2014). Thermal and geodynamic contributions to the elevation of the Altiplano-Puna plateau. Physics of the Earth and Planetary Interiors, 237, 51-64. https://doi.org/10.1016/j.pepi.2014.10.002

Priestley, K, \& Mckenzie, D. (2006). The thermal structure of the lithosphere from shear wave velocities. Earth and Planetary Science Letters, 244(1-2), 285-301.

https://doi.org/10.1016/j.eps1.2006.01.008

Priestley, Keith, \& McKenzie, D. (2013). The relationship between shear wave velocity, temperature, attenuation and viscosity in the shallow part of the mantle. Earth and Planetary Science Letters, 381, 78-91. https://doi.org/10.1016/j.eps1.2013.08.022

Ramos, V. A., \& Folguera, A. (2009). Andean flat-slab subduction through time. Geological Society, London, Special Publications, 327(1), 31-54. https://doi.org/10.1144/SP327.3

Ramos, V. A., Cegarra, M., \& Cristallini, E. (1996). Cenozoic tectonics of the High Andes of west-central Argentina (30-36 S latitude). Tectonophysics, 259(1-3), 185-200.

https://doi.org/10.1016/0040-1951(95)00064-X

Ramos, V. A., Cristallini, E. O., \& Pérez, D. J. (2002). The Pampean flat-slab of the Central Andes. Flat-Slab Subduction in the Andes, 15(1), 59-78. https://doi.org/10.1016/S08959811(02)00006-8

Rodriguez Piceda, C., Scheck Wenderoth, M., Gomez Dacal, M. L., Bott, J., Prezzi, C. B., \& Strecker, M. R. (2021). Lithospheric density structure of the southern Central Andes constrained by 3D data-integrative gravity modelling. International Journal of Earth Sciences, 110(7), 2333-2359. https://doi.org/10.1007/s00531-020-01962-1

Rudnick, R. L., \& Gao, S. (2003). 3.01 - Composition of the Continental Crust. In H. D. Holland \& K. K. Turekian (Eds.), Treatise on Geochemistry (pp. 1-64). Oxford: Pergamon. https://doi.org/10.1016/B0-08-043751-6/03016-4

Sánchez, M. A., Ariza, J. P., García, H. P., Gianni, G. M., Weidmann, M. C., Folguera, A., et al. (2018). Thermo-mechanical analysis of the Andean lithosphere over the Chilean-Pampean flat-slab region. Journal of South American Earth Sciences, 87, 247-257.

https://doi.org/10.1016/j.jsames.2017.09.036

Sánchez, M. A., García, H. P. A., Acosta, G., Gianni, G. M., Gonzalez, M. A., Ariza, J. P., et al. (2019). Thermal and lithospheric structure of the Chilean-Pampean flat-slab from gravity and magnetic data. In Andean Tectonics (pp. 487-507). Elsevier.

https://doi.org/10.1016/B978-0-12-816009-1.00005-8

Saxena, S. K., \& Shen, G. (1992). Assessed data on heat capacity, thermal expansion, and compressibility for some oxides and silicates. Journal of Geophysical Research, 97(B13), 19813. https://doi.org/10.1029/92JB01555

Scarfi, L., \& Barberi, G. (2019). New insights on the tectonic structure of the Southern Central Andes-Western Argentina-from seismic tomography. Geology, Earth and Marine Sciences. 
Schaeffer, A. J., \& Lebedev, S. (2013). Global shear speed structure of the upper mantle and transition zone. Geophysical Journal International, 194(1), 417-449.

https://doi.org/10.1093/gji/ggt095

Scheck-Wenderoth, M., Cacace, M., Maystrenko, Y. P., Cherubini, Y., Noack, V., Kaiser, B. O., et al. (2014). Models of heat transport in the Central European Basin System: Effective mechanisms at different scales. Marine and Petroleum Geology, 55, 315-331.

https://doi.org/10.1016/j.marpetgeo.2014.03.009

Schurr, B., Rietbrock, A., Asch, G., Kind, R., \& Oncken, O. (2006). Evidence for lithospheric detachment in the central Andes from local earthquake tomography. Tectonophysics, 415(1), 203-223. https://doi.org/10.1016/j.tecto.2005.12.007

Sharples, W., Jadamec, M. A., Moresi, L. N., \& Capitanio, F. A. (2014). Overriding plate controls on subduction evolution. Journal of Geophysical Research: Solid Earth, 119(8), 6684-6704. https://doi.org/10.1002/2014JB011163

Sigismondi, M. E. (2012). Estudio de la deformación litosférica de la cuenca Neuquina: estructura termal, datos de gravedad y sísmica de reflexión.

Sippel, J., Meeßen, C., Cacace, M., Mechie, J., Fishwick, S., Heine, C., et al. (2017). The Kenya rift revisited: insights into lithospheric strength through data-driven 3-D gravity and thermal modelling. Solid Earth, 8(1), 45-81. https://doi.org/10.5194/se-8-45-2017

Sobolev, S. V., Zeyen, H., Stoll, G., Werling, F., Altherr, R., \& Fuchs, K. (1996). Upper mantle temperatures from teleseismic tomography of French Massif Central including effects of composition, mineral reactions, anharmonicity, anelasticity and partial melt. Earth and Planetary Science Letters, 139(1), 147-163. https://doi.org/10.1016/0012-821X(95)00238-8

Spooner, C., Scheck-Wenderoth, M., Cacace, M., Götze, H.-J., \& Luijendijk, E. (2020). The 3D thermal field across the Alpine orogen and its forelands and the relation to seismicity. Global and Planetary Change, 193, 103288. https://doi.org/10.1016/j.gloplacha.2020.103288

Steinberger, B., \& Calderwood, A. R. (2006). Models of large-scale viscous flow in the Earth's mantle with constraints from mineral physics and surface observations. Geophysical Journal International, 167(3), 1461-1481. https://doi.org/10.1111/j.1365-246X.2006.03131.x

Stixrude, L., \& Lithgow-Bertelloni, Carolina. (2005). Mineralogy and elasticity of the oceanic upper mantle: Origin of the low-velocity zone. Journal of Geophysical Research, 110(B3), B03204. https://doi.org/10.1029/2004JB002965

Syracuse, E. M., van Keken, P. E., \& Abers, G. A. (2010). The global range of subduction zone thermal models. Special Issue on Deep Slab and Mantle Dynamics, 183(1), 73-90. https://doi.org/10.1016/j.pepi.2010.02.004

Tassara, A., \& Yáñez, G. (2003). Relación entre el espesor elástico de la litosfera y la segmentación tectónica del margen andino (15-47 S). Andean Geology, 30(2), 159-186.

Taylor, S. R. (1967). The origin and growth of continents. Tectonophysics, 4(1), 17-34. https://doi.org/10.1016/0040-1951(67)90056-X

Tesauro, M., Kaban, M. K., \& Cloetingh, S. A. P. L. (2009). How rigid is Europe's lithosphere? Geophysical Research Letters, 36(16). https://doi.org/10.1029/2009GL039229 
Thompson, A. B., Schulmann, K., Jezek, J., \& Tolar, V. (2001). Thermally softened continental extensional zones (arcs and rifts) as precursors to thickened orogenic belts. Tectonophysics, 332(1), 115-141. https://doi.org/10.1016/S0040-1951(00)00252-3

Turcotte, D. L., \& Schubert, G. (2002). Geodynamics. Cambridge university press.

Uyeda, S., \& Watanabe, T. (1982). Terrestrial heat flow in western South America. Tectonophysics, 83(1-2), 63-70. https://doi.org/10.1016/0040-1951(82)90007-5

Vilà, M., Fernández, M., \& Jiménez-Munt, I. (2010). Radiogenic heat production variability of some common lithological groups and its significance to lithospheric thermal modeling. Tectonophysics, 490(3-4), 152-164. https://doi.org/10.1016/j.tecto.2010.05.003

Wagner, L., Beck, S., Zandt, G., \& Ducea, M. (2006). Depleted lithosphere, cold, trapped asthenosphere, and frozen melt puddles above the flat slab in central Chile and Argentina. Earth and Planetary Science Letters, 245(1-2), 289-301.

https://doi.org/10.1016/j.epsl.2006.02.014

Wagner, L. S., Beck, S., \& Zandt, G. (2005). Upper mantle structure in the south central Chilean subduction zone $\left(30^{\circ}\right.$ to $\left.36^{\circ} \mathrm{S}\right)$. Journal of Geophysical Research: Solid Earth, 110(B1). https://doi.org/10.1029/2004JB003238

Wangen, M. (1994). The blanketing effect in sedimentary basins. Basin Research, 7(4), 283298.

Ward, K. M., Porter, R. C., Zandt, G., Beck, S. L., Wagner, L. S., Minaya, E., \& Tavera, H. (2013). Ambient noise tomography across the Central Andes. Geophysical Journal International, 194(3), 1559-1573. https://doi.org/10.1093/gji/ggt166

Watts, A. B., \& Burov, E. B. (2003). Lithospheric strength and its relationship to the elastic and seismogenic layer thickness. Earth and Planetary Science Letters, 213(1), 113-131. https://doi.org/10.1016/S0012-821X(03)00289-9

Wyllie, P. (1981). Plate tectonics and magma genesis. Geologische Rundschau, 70(1), 128153. https://doi.org/10.1007/BF01764318

Xu, Y., Shankland, T. J., Linhardt, S., Rubie, D. C., Langenhorst, F., \& Klasinski, K. (2004). Thermal diffusivity and conductivity of olivine, wadsleyite and ringwoodite to $20 \mathrm{GPa}$ and 1373 K. Physics of the Earth and Planetary Interiors, 143-144, 321-336.

https://doi.org/10.1016/j.pepi.2004.03.005

Yáñez, G., \& Cembrano, J. (2004). Role of viscous plate coupling in the late Tertiary Andean tectonics. Journal of Geophysical Research: Solid Earth, 109(B2).

https://doi.org/10.1029/2003JB002494

Yáñez, G. A., Ranero, C. R., von Huene, R., \& Díaz, J. (2001). Magnetic anomaly interpretation across the southern central Andes (32-34 S): The role of the Juan Fernández Ridge in the late Tertiary evolution of the margin. Journal of Geophysical Research: Solid Earth, 106(B4), 6325-6345.

Zapata, S., Sobel, E. R., Del Papa, C., \& Glodny, J. (2020). Upper Plate Controls on the Formation of Broken Foreland Basins in the Andean Retroarc Between $26^{\circ} \mathrm{S}$ and $28^{\circ} \mathrm{S}$ : From 
Cretaceous Rifting to Paleogene and Miocene Broken Foreland Basins. Geochemistry, Geophysics, Geosystems, 21(7). https://doi.org/10.1029/2019GC008876

Artemieva, I. (2011). Lithosphere: an interdisciplinary approach. Cambridge, England: Cambridge University Press.

Assumpção, M., Feng, M., Tassara, A., \& Julià, J. (2013). Models of crustal thickness for South America from seismic refraction, receiver functions and surface wave tomography. Tectonophysics, 609, 82-96. https://doi.org/10.1016/j.tecto.2012.11.014

Astini, R., Benedetto, J., \& Vaccari, N. (1995). The early Paleozoic evolution of the Argentine Precordillera as a Laurentian rifted, drifted, and collided terrane: A geodynamic model. Geological Society of America Bulletin, 107(3), 253-273. https://doi.org/10.1130/0016-7606(1995)107<0253:TEPEOT>2.3.CO;2

Astort, A., Colavitto, B., Sagripanti, L., García, H., Echaurren, A., Soler, S., et al. (2019). Crustal and Mantle Structure Beneath the Southern Payenia Volcanic Province Using Gravity and Magnetic Data. Tectonics, 38(1), 144-158. https://doi.org/10.1029/2017TC004806

Azcuy, C., \& Caminos, R. (1987). El Sistema Carbonifero en la Republica Argentina. Diastrofismo. In El sistema carbonífero en la República Argentina (pp. 239-251). Córdoba, Argentina: Academia Nacional de Ciencias.

Barazangi, M., \& Isacks, B. L. (1976). Spatial distribution of earthquakes and subduction of the Nazca plate beneath South America. Geology, 4(11), 686-692.

Barrionuevo, M., Liu, S., Mescua, J., Yagupsky, D., Quinteros, J., Giambiagi, L., et al. (2021). The influence of variations in crustal composition and lithospheric strength on the evolution of deformation processes in the southern Central Andes: Insights from geodynamic models. International Journal of Earth Sciences. https://doi.org/10.1007/s00531-021-01982-5

Berckhemer, H., Kampfmann, W., Aulbach, E., \& Schmeling, H. (1982). Shear modulus and $\mathrm{Q}$ of forsterite and dunite near partial melting from forced-oscillation experiments. Physics of the Earth and Planetary Interiors, 29(1), 30-41. https://doi.org/10.1016/0031-9201(82)90135-2

Bianchi, M., Heit, B., Jakovlev, A., Yuan, X., Kay, S., Sandvol, E., et al. (2013). Teleseismic tomography of the southern Puna plateau in Argentina and adjacent regions. Tectonophysics, 586, 65-83. https://doi.org/10.1016/j.tecto.2012.11.016

Boonma, K., Kumar, A., Garcia-Castellanos, D., Jiménez-Munt, I., \& Fernández, M. (2019). Lithospheric mantle buoyancy: the role of tectonic convergence and mantle composition. Scientific Reports, 9(1), 17953. https://doi.org/10.1038/s41598-01954374-w

Boyce, D., Charrier, R., \& Farías, M. (2020). The First Andean Compressive Tectonic Phase: Sedimentologic and Structural Analysis of Mid-Cretaceous Deposits in the Coastal Cordillera, Central Chile (32॰50’S). Tectonics, 39(2). https://doi.org/10.1029/2019TC005825

Brocher, T. M. (2005). Empirical Relations between Elastic Wavespeeds and Density in the Earth's Crust. Bulletin of the Seismological Society of America, 95(6), 2081-2092. https://doi.org/10.1785/0120050077

Burov, E., \& Diament, M. (1995). The effective elastic thickness (Te) of continental lithosphere: What does it really mean? Journal of Geophysical Research, 100, 39053927. https://doi.org/10.1029/94JB02770

Burov, Evgueni. (2007). Coupled lithosphere-surface processes in collision context. In Thrust Belts and Foreland Basins (pp. 3-40). Heidelberg, Germany: Springer. 
Cacace, M., \& Jacquey, A. B. (2017). Flexible parallel implicit modeling of coupled thermalhydraulic-mechanical processes in fractured rocks. Solid Earth, 8(5), 921-941. https://doi.org/10.5194/se-8-921-2017

Cahill, T., \& Isacks, B. L. (1992). Seismicity and shape of the subducted Nazca Plate. Journal of Geophysical Research, 97(B12), 17503. https://doi.org/10.1029/92JB00493

Calixto, F. J., Sandvol, E., Kay, S., Mulcahy, P., Heit, B., Yuan, X., et al. (2013). Velocity structure beneath the southern Puna plateau: Evidence for delamination: Velocity Structure in The Southern Puna. Geochemistry, Geophysics, Geosystems, 14(10), 4292-4305. https://doi.org/10.1002/ggge.20266

Cammarano, F., Goes, S., Vacher, P., \& Giardini, D. (2003). Inferring upper-mantle temperatures from seismic velocities. Physics of the Earth and Planetary Interiors, 138(3), 197-222. https://doi.org/10.1016/S0031-9201(03)00156-0

Čermák, V., \& Rybach, L. (1982). Thermal conductivity and specific heat of minerals and rocks. In G. Angenheister (Ed): Landolt-Börnstein: Numerical Data and Functional Relationships in Science and Technology (pp. 305-343), Berlin-Heidelberg, Germany: Springer.

Chen, L., Song, X., Gerya, T. V., Xu, T., \& Chen, Y. (2019). Crustal melting beneath orogenic plateaus: Insights from 3-D thermo-mechanical modeling. Tectonophysics, 761, 1-15. https://doi.org/10.1016/j.tecto.2019.03.014

Christensen, N. I., \& Mooney, W. D. (1995). Seismic velocity structure and composition of the continental crust: A global view. Journal of Geophysical Research: Solid Earth, 100(B6), 9761-9788. https://doi.org/10.1029/95JB00259

Č́žková, H., \& Bina, C. R. (2013). Effects of mantle and subduction-interface rheologies on slab stagnation and trench rollback. Earth and Planetary Science Letters, 379, 95-103. https://doi.org/10.1016/j.epsl.2013.08.011

Collins, W. J. (2002). Hot orogens, tectonic switching, and creation of continental crust. Geology, 30(6), 535-538. https://doi.org/10.1130/00917613(2002)030<0535:HOTSAC > 2.0.CO;2

Collo, G., Ezpeleta, M., Dávila, F. M., Giménez, M., Soler, S., Martina, F., et al. (2018). Basin Thermal Structure in the Chilean-Pampean Flat Subduction Zone. In The Evolution of the Chilean-Argentinean Andes (pp. 537-564). Springer.

Conceição, R. V., Mallmann, G., Koester, E., Schilling, M., Bertotto, G. W., \& RodriguezVargas, A. (2005). Andean subduction-related mantle xenoliths: Isotopic evidence of Sr-Nd decoupling during metasomatism. Lithos, 82(3-4), 273-287. https://doi.org/10.1016/j.lithos.2004.09.022

Contreras-Reyes, E., Grevemeyer, I., Flueh, E. R., \& Reichert, C. (2008). Upper lithospheric structure of the subduction zone offshore of southern Arauco peninsula, Chile, at $\sim 38^{\circ}$ S. Journal of Geophysical Research, 113(B7), B07303. https://doi.org/10.1029/2007JB005569

del Papa, C., Hongn, F., Powell, J., Payrola, P., Do Campo, M., Strecker, M. R., et al. (2013). Middle Eocene-Oligocene broken-foreland evolution in the Andean Calchaqui Valley, NW Argentina: insights from stratigraphic, structural and provenance studies. Basin Research, 25(5), 574-593. https://doi.org/10.1111/bre.12018

Deschamps, F., Trampert, J., \& Snieder, R. (2002). Anomalies of temperature and iron in the uppermost mantle inferred from gravity data and tomographic models. Physics of the Earth and Planetary Interiors, 129(3), 245-264. https://doi.org/10.1016/S00319201(01)00294-1

Deshayes, P. (2008, November). Velocity and attenuation tomography of the subduction zone in central Chile-western Argentina $\left(29^{\circ} \mathrm{S}-34^{\circ} \mathrm{S}\right)$ from local seismic data: contribution to the mineralogical composition study. (Theses). Université Nice Sophia Antipolis. Retrieved from https://tel.archives-ouvertes.fr/tel-00360063 
Feng, M., van der Lee, S., \& Assumpção, M. (2007). Upper mantle structure of South America from joint inversion of waveforms and fundamental mode group velocities of Rayleigh waves. Journal of Geophysical Research, 112(B4). https://doi.org/10.1029/2006JB004449

Fennell, L. M., Folguera, A., Naipauer, M., Gianni, G., Rojas Vera, E. A., Bottesi, G., \& Ramos, V. A. (2017). Cretaceous deformation of the southern Central Andes: synorogenic growth strata in the Neuquén Group ( $\left.35^{\circ} 30^{\prime}-37^{\circ} \mathrm{S}\right)$. Basin Research, 29(S1), 51-72. https://doi.org/10.1111/bre.12135

Freymark, J., Sippel, J., Scheck-Wenderoth, M., Bär, K., Stiller, M., Fritsche, J.-G., \& Kracht, M. (2017). The deep thermal field of the Upper Rhine Graben. Tectonophysics, 694, 114-129. https://doi.org/10.1016/j.tecto.2016.11.013

Furlong, K. P., \& Chapman, D. S. (2013). Heat Flow, Heat Generation, and the Thermal State of the Lithosphere. Annual Review of Earth and Planetary Sciences, 41(1), 385-410. https://doi.org/10.1146/annurev.earth.031208.100051

Gao, Y., Tilmann, F., van Herwaarden, D., Thrastarson, S., Fichtner, A., Heit, B., et al. (2021). Full Waveform Inversion beneath the Central Andes: Insight into the dehydration of the Nazca slab and delamination of the back-arc lithosphere. Journal of Geophysical Research. https://doi.org/10.1029/2021JB021984

Gerbault, M., Cembrano, J., Mpodozis, C., Farias, M., \& Pardo, M. (2009). Continental margin deformation along the Andean subduction zone: Thermo-mechanical models. Physics of the Earth and Planetary Interiors, 177(3), 180-205. https://doi.org/10.1016/j.pepi.2009.09.001

Giambiagi, L., Mescua, J., Bechis, F., Tassara, A., \& Hoke, G. (2012). Thrust belts of the southern Central Andes: Along-strike variations in shortening, topography, crustal geometry, and denudation. Geological Society of America Bulletin, 124(7-8), 13391351. https://doi.org/10.1130/B30609.1

Giambiagi, L. B., Alvarez, P. P., Godoy, E., \& Ramos, V. A. (2003). The control of preexisting extensional structures on the evolution of the southern sector of the Aconcagua fold and thrust belt, southern Andes. Tectonophysics, 369(1-2), 1-19. https://doi.org/10.1016/S0040-1951(03)00171-9

Gilbert, H., Beck, S., \& Zandt, G. (2006). Lithospheric and upper mantle structure of central Chile and Argentina. Geophysical Journal International, 165(1), 383-398. https://doi.org/10.1111/j.1365-246X.2006.02867.x

Goes, S., Govers, R., \& Vacher, P. (2000). Shallow mantle temperatures under Europe from P and S wave tomography. Journal of Geophysical Research, 105(B5), 11153-11169. https://doi.org/10.1029/1999JB900300

González-Vidal, D., Obermann, A., Tassara, A., Bataille, K., \& Lupi, M. (2018). Crustal model of the Southern Central Andes derived from ambient seismic noise Rayleighwave tomography. Tectonophysics, 744, 215-226. https://doi.org/10.1016/j.tecto.2018.07.004

Gutscher, M.-A. (2002). Andean subduction styles and their effect on thermal structure and interplate coupling. Journal of South American Earth Sciences, 15(1), 3-10. https://doi.org/10.1016/S0895-9811(02)00002-0

Hamza, V. M., Cardoso, R. R., \& Ponte Neto, C. F. (2008). Spherical harmonic analysis of earth's conductive heat flow. International Journal of Earth Sciences, 97(2), 205-226. https://doi.org/10.1007/s00531-007-0254-3

Hamza, V. M., \& Muñoz, M. (1996). Heat flow map of South America. Geothermics, 25(6), 599-646. https://doi.org/10.1016/S0375-6505(96)00025-9

Hamza, V. M., Dias, F. J. S. S., Gomes, A. J. L., \& Terceros, Z. G. D. (2005). Numerical and functional representations of regional heat flow in South America. Physics of the 
Earth and Planetary Interiors, 152(4), 223-256.

https://doi.org/10.1016/j.pepi.2005.04.009

Hasterok, D., \& Chapman, D. (2011). Heat production and geotherms for the continental lithosphere. Earth and Planetary Science Letters, 307(1-2), 59-70. https://doi.org/10.1016/j.eps1.2011.04.034

He, L., Hu, S., Huang, S., Yang, W., Wang, J., Yuan, Y., \& Yang, S. (2008). Heat flow study at the Chinese Continental Scientific Drilling site: Borehole temperature, thermal conductivity, and radiogenic heat production. Journal of Geophysical Research, 113(B2), B02404. https://doi.org/10.1029/2007JB004958

Heit, B., Bianchi, M., Yuan, X., Kay, S. M., Sandvol, E., Kumar, P., et al. (2014). Structure of the crust and the lithosphere beneath the southern Puna plateau from teleseismic receiver functions. Earth and Planetary Science Letters, 385, 1-11. https://doi.org/10.1016/j.epsl.2013.10.017

Henry, S. G., \& Pollack, H. N. (1988). Terrestrial heat flow above the Andean Subduction Zone in Bolivia and Peru. Journal of Geophysical Research: Solid Earth, 93(B12), 15153-15162. https://doi.org/10.1029/JB093iB12p15153

Hilley, G. E., Blisniuk, P. M., \& Strecker, M. R. (2005). Mechanics and erosion of basementcored uplift provinces. Journal of Geophysical Research: Solid Earth, 110(B12). https://doi.org/10.1029/2005JB003704

Holt, A. F., \& Condit, C. B. (2021). Slab temperature evolution over the lifetime of a subduction zone. Geochemistry, Geophysics, Geosystems, 22(6). https://doi.org/10.1029/2020GC009476

Hongn, F., del Papa, C., Powell, J., Petrinovic, I., Mon, R., \& Deraco, V. (2007). Middle Eocene deformation and sedimentation in the Puna-Eastern Cordillera transition $\left(23^{\circ}\right.$ $26^{\circ} \mathrm{S}$ ): Control by preexisting heterogeneities on the pattern of initial Andean shortening. Geology, 35(3), 271-274. https://doi.org/10.1130/G23189A.1

Hongn, F., Mon, R., Petrinovic, I., del Papa, C., \& Powell, J. (2010). Inversión y reactivación tectónicas cretácico-cenozoicas en el noroeste argentino: influencia de las heterogeneidades del basamento Neoproterozoico-Paleozoico inferior. Revista de La Asociación Geológica Argentina, 66(1-2), 38-53.

Hu, J., Liu, L., Hermosillo, A., \& Zhou, Q. (2016). Simulation of late Cenozoic South American flat-slab subduction using geodynamic models with data assimilation. Earth and Planetary Science Letters, 438, 1-13. https://doi.org/10.1016/j.epsl.2016.01.011

Hyndman, R. D. (2005). Subduction zone backarcs, mobile belts, and orogenic heat. GSA TODAY, 7.

Ibarra, F., Liu, S., Meeßen, C., Prezzi, C. B., Bott, J., Scheck-Wenderoth, M., et al. (2019). 3D data-derived lithospheric structure of the Central Andes and its implications for deformation: Insights from gravity and geodynamic modeling. Tectonophysics, 766, 453-468. https://doi.org/10.1016/j.tecto.2019.06.025

Ibarra, F., \& Prezzi, C. B. (2019). The thermo-mechanical state of the Andes in the AltiplanoPuna region: insights from Curie isotherm and effective elastic thickness determination. Revista de La Asociación Geológica Argentina, 76(4), 352-362.

Ibarra, F., Prezzi, C. B., Bott, J., Scheck-Wenderoth, M., \& Strecker, M. R. (2021). Distribution of Temperature and Strength in the Central Andean Lithosphere and Its Relationship to Seismicity and Active Deformation. Journal of Geophysical Research: Solid Earth, 126(5). https://doi.org/10.1029/2020JB021231

Jacquey, A. B., \& Cacace, M. (2017). GOLEM, a MOOSE-based application (Version v1.0). Zenodo. https://doi.org/10.5281/zenodo.999401

Jalowitzki, T. L. R., Conceição, R. V., Orihashi, Y., Bertotto, G. W., Nakai, S., \& Schilling, M. E. (2010). Evolução geoquímica de peridotitos e piroxenitos do Manto Litosférico 
Subcontinental do vulcão Agua Poca, Terreno Cuyania, Argentina. Pesquisas em Geociências, 37(2), 143. https://doi.org/10.22456/1807-9806.22656

Jaupart, C., Mareschal, J.-C., \& Iarotsky, L. (2016). Radiogenic heat production in the continental crust. Lithos, 262, 398-427. https://doi.org/10.1016/j.lithos.2016.07.017

Jones, R. E., De Hoog, J. C., Kirstein, L. A., Kasemann, S. A., Hinton, R., Elliott, T., \& Litvak, V. D. (2014). Temporal variations in the influence of the subducting slab on Central Andean arc magmas: Evidence from boron isotope systematics. Earth and Planetary Science Letters, 408, 390-401. https://doi.org/10.1016/j.epsl.2014.10.004

Jones, R. E., Kirstein, L. A., Kasemann, S. A., Dhuime, B., Elliott, T., Litvak, V. D., et al. (2015). Geodynamic controls on the contamination of Cenozoic arc magmas in the southern Central Andes: Insights from the $\mathrm{O}$ and $\mathrm{Hf}$ isotopic composition of zircon. Geochimica et Cosmochimica Acta, 164, 386-402.

Jones, R. E., Kirstein, L. A., Kasemann, S. A., Litvak, V. D., Poma, S., Alonso, R. N., \& Hinton, R. (2016). The role of changing geodynamics in the progressive contamination of Late Cretaceous to Late Miocene arc magmas in the southern Central Andes. Lithos, 262, 169-191. https://doi.org/10.1016/j.lithos.2016.07.002

Jordan, T. E., Isacks, B., Ramos, V. A., \& Allmendinger, R. W. (1983). Mountain building in the Central Andes. Episodes, 3(3), 20-26.

Kaban, M. K., Tesauro, M., Mooney, W. D., \& Cloetingh, S. A. P. L. (2014). Density, temperature, and composition of the North American lithosphere-New insights from a joint analysis of seismic, gravity, and mineral physics data: 1 . Density structure of the crust and upper mantle. Geochemistry, Geophysics, Geosystems, 15(12), 4781-4807. https://doi.org/10.1002/2014GC005483

Kaislaniemi, L., Hunen, J., \& Bouilhol, P. (2018). Lithosphere Destabilization by Melt Weakening and Crust-Mantle Interactions: Implications for Generation of GraniteMigmatite Belts, 15.

Kay, S. M., \& Mpodozis, C. (2002). Magmatism as a probe to the Neogene shallowing of the Nazca plate beneath the modern Chilean ${ }^{-}$at-slab. Journal of South American Earth Sciences, 19.

Kay, S. M., Coira, B., \& Viramonte, J. (1994). Young mafic back arc volcanic rocks as indicators of continental lithospheric delamination beneath the Argentine Puna Plateau, central Andes. Journal of Geophysical Research, 99(B12), 24323-24339. https://doi.org/10.1029/94JB00896

Kay, S. M., Burns, W. M., Copeland, P., \& Mancilla, O. (2006). Upper Cretaceous to Holocene magmatism and evidence for transient Miocene shallowing of the Andean subduction zone under the northern Neuquén Basin. In S. M. Kay \& V. A. Ramos (Eds.), Evolution of an Andean Margin: A Tectonic and Magmatic View from the Andes to the Neuque $n$ Basin (35 $-39^{\circ}$ S lat) (Vol. 407, p. 0). Geological Society of America. https://doi.org/10.1130/2006.2407(02)

Kennett, B. L. N., Engdahl, E. R., \& Buland, R. (1995). Constraints on seismic velocities in the Earth from traveltimes. Geophysical Journal International, 122(1), 108-124. https://doi.org/10.1111/j.1365-246X.1995.tb03540.x

Kley, J., Monaldi, C. R., \& Salfity, J. A. (1999). Along-strike segmentation of the Andean foreland: causes and consequences. Tectonophysics, 301(1), 75-94. https://doi.org/10.1016/S0040-1951(98)90223-2

Kley, Jonas, \& Monaldi, C. R. (2002). Tectonic inversion in the Santa Barbara System of the central Andean foreland thrust belt, northwestern Argentina. Tectonics, 21(6), 11-111-18. https://doi.org/10.1029/2002TC902003

Kusznir, N. J., \& Park, R. G. (1984). Intraplate lithosphere deformation and the strength of the lithosphere. Geophysical Journal International, 79(2), 513-538. https://doi.org/10.1111/j.1365-246X.1984.tb02238.x 
Leng, W., \& Mao, W. (2015). Geodynamic modeling of thermal structure of subduction zones. Science China Earth Sciences, 58(7), 1070-1083. https://doi.org/10.1007/s11430-015-5107-5

Liang, X., Sandvol, E., Kay, S., Heit, B., Yuan, X., Mulcahy, P., et al. (2014). Delamination of southern Puna lithosphere revealed by body wave attenuation tomography: Attenuation tomography of southern Puna. Journal of Geophysical Research: Solid Earth, 119(1), 549-566. https://doi.org/10.1002/2013JB010309

Liu, S. (2020). Controls of foreland-deformation patterns in the orogen-foreland shortening system. Retrieved from https://publishup.unipotsdam.de/frontdoor/index/index/docId/44573. University of Potsdam

Llambias, E. J., \& Sato, A. M. (1990). El Batolito de Colangüil (29-31 S) cordillera frontal de Argentina: estructura y marco tectonico. Andean Geology, 17(1), 89-108.

LLambias, E. J., Kleiman, L. E., \& Salvarredi, J. A. (1993). El magmatismo gondwánico (pp. 53-64). Presented at the Geología y Recursos Naturales de Mendoza (Ramos, V.; editor). Congreso Geológico Argentino.

Lucazeau, F. (2019). Analysis and Mapping of an Updated Terrestrial Heat Flow Data Set. Geochemistry, Geophysics, Geosystems, 20(8), 4001-4024. https://doi.org/10.1029/2019GC008389

Lucazeau, F., \& Le Douaran, S. (1985). The blanketing effect of sediments in basins formed by extension: a numerical model. Application to the Gulf of Lion and Viking graben. Earth and Planetary Science Letters, 74(1), 92-102. https://doi.org/10.1016/0012821X(85)90169-4

Maaløe, S., \& Aoki, K. (1977). The major element composition of the upper mantle estimated from the composition of lherzolites. Contributions to Mineralogy and Petrology, 63(2), 161-173. https://doi.org/10.1007/BF00398777

Manea, V.C., Manea, M., Ferrari, L., Orozco-Esquivel, T., Valenzuela, R. W., Husker, A., \& Kostoglodov, V. (2017). A review of the geodynamic evolution of flat slab subduction in Mexico, Peru, and Chile. Tectonophysics, 695, 27-52. https://doi.org/10.1016/j.tecto.2016.11.037

Manea, V. C., \& Manea, M. (2011). Flat-slab thermal structure and evolution beneath central Mexico. Pure and Applied Geophysics, 168(8-9), 1475-1487.

Manea, V. C., Pérez-Gussinyé, M., \& Manea, M. (2012). Chilean flat slab subduction controlled by overriding plate thickness and trench rollback. Geology, 40(1), 35-38. https://doi.org/10.1130/G32543.1

Mareschal, J.C., \& Jaupart, C. (2013). Radiogenic heat production, thermal regime and evolution of continental crust. Moho: 100 Years after Andrija Mohorovicic, 609, 524 534. https://doi.org/10.1016/j.tecto.2012.12.001

Marot, M., Monfret, T., Gerbault, M., Nolet, G., Ranalli, G., \& Pardo, M. (2014). Flat versus normal subduction zones: a comparison based on 3-D regional traveltime tomography and petrological modeling of central Chile and western Argentina $\left(29^{\circ}-35^{\circ} \mathrm{S}\right)$. Geophysical Journal International, 199(3), 1633-1654. https://doi.org/10.1093/gji/ggu355

Meeßen, C. (2017). VelocityConversion. V. v1.0.1. GFZ Data Services. Retrieved from http://doi.org/10.5880/GFZ.6.1.2017.001

Meeßen, C. (2019). The thermal and rheological state of the Northern Argentinian foreland basins. Retrieved from https://publishup.unipotsdam.de/frontdoor/index/index/docId/43994. University of Potsdam

Meeßen, C. (2020). VeloDT v1.2 (Version v1.2). Zenodo. https://doi.org/10.5281/zenodo.3895784 
Mpodozis, C., \& Kay, S. M. (1990). Provincias magmáticas ácidas y evolución tectónica de Gondwana: Andes chilenos (28-31 S). Andean Geology, 17(2), 153-180. http://dx.doi.org/10.5027/andgeoV17n2-a03

Copernicus Climate Change Service, J. (2019). ERA5-Land monthly averaged data from 1981 to present. Retrieved from doi.org/10.24381/cds.68d2bb30

Nacif, S., Lupari, M., Triep, E. G., Nacif, A., Álvarez, O., Folguera, A., \& Gímenez, M. (2017). Change in the pattern of crustal seismicity at the Southern Central Andes from a local seismic network. Tectonophysics, 708, 56-69. https://doi.org/10.1016/j.tecto.2017.04.012

Oncken, O., Chong, G., Gerhard, F., Giese, P., Götze, H.-J., Ramos, V. A., et al. (2006). The Andes: Active Subduction Orogeny (1st ed.). Heidelberg-Berlin, Germany: Springer.

Penniston-Dorland, S. C., Kohn, M. J., \& Manning, C. E. (2015). The global range of subduction zone thermal structures from exhumed blueschists and eclogites: Rocks are hotter than models. Earth and Planetary Science Letters, 428, 243-254. https://doi.org/10.1016/j.epsl.2015.07.031

Pérez Luján, S. B., Ammirati, J.B., Alvarado, P., \& Vujovich, G. I. (2015). Constraining a mafic thick crust model in the Andean Precordillera of the Pampean flat slab subduction region. Journal of South American Earth Sciences, 64, 325-338. https://doi.org/10.1016/j.jsames.2015.09.005

Pesicek, J. D., Engdahl, E. R., Thurber, C. H., DeShon, H. R., \& Lange, D. (2012). Mantle subducting slab structure in the region of the 2010 M8.8 Maule earthquake (30-40 $\mathrm{S}$ ), Chile: Mantle subducting slab structure in Chile. Geophysical Journal International, 191(1), 317-324. https://doi.org/10.1111/j.1365-246X.2012.05624.x

Porter, R., Gilbert, H., Zandt, G., Beck, S., Warren, L., Calkins, J., et al. (2012). Shear wave velocities in the Pampean flat-slab region from Rayleigh wave tomography: Implications for slab and upper mantle hydration. Journal of Geophysical Research, 117(B11). https://doi.org/10.1029/2012JB009350

Prezzi, C., Iglesia Llanos, M. P., Götze, H.-J., \& Schmidt, S. (2014). Thermal and geodynamic contributions to the elevation of the Altiplano-Puna plateau. Physics of the Earth and Planetary Interiors, 237, 51-64. https://doi.org/10.1016/j.pepi.2014.10.002

Priestley, K, \& McKenzie, D. (2006). The thermal structure of the lithosphere from shear wave velocities. Earth and Planetary Science Letters, 244(1-2), 285-301. https://doi.org/10.1016/j.eps1.2006.01.008

Priestley, K., McKenzie, D., \& Ho, T. (2018). A Lithosphere-Asthenosphere Boundary-a Global Model Derived from Multimode Surface-Wave Tomography and Petrology. In Lithospheric Discontinuities (pp. 111-123). American Geophysical Union (AGU). https://doi.org/10.1002/9781119249740.ch6

Ramos, V. A. (1988). The tectonics of the Central Andes; $30^{\circ}$ to $33^{\circ} \mathrm{S}$ latitude. In S. P. Clark Jr., B. C. Burchfiel, \& J. Suppe (Eds.), Processes in Continental Lithospheric Deformation (Vol. 218, p. 0). Geological Society of America. https://doi.org/10.1130/SPE218-p31

Ramos, V. A., Cristallini, E. O., \& Pérez, D. J. (2002). The Pampean flat-slab of the Central Andes. Flat-Slab Subduction in the Andes, 15(1), 59-78. https://doi.org/10.1016/S0895-9811(02)00006-8

Rodriguez Piceda, C., Scheck-Wenderoth, M., Gomez Dacal, M. L., Bott, J., Prezzi, C. B., \& Strecker, M. R. (2020). Lithospheric density structure of the southern Central Andes constrained by 3D data-integrative gravity modeling. International Journal of Earth Sciences. https://doi.org/10.1007/s00531-020-01962-1 
Rudnick, R. L., \& Gao, S. (2003). 3.01 - Composition of the Continental Crust. In H. D. Holland \& K. K. Turekian (Eds.), Treatise on Geochemistry (pp. 1-64). Oxford: Pergamon. https://doi.org/10.1016/B0-08-043751-6/03016-4

Sánchez, M. A., Ariza, J. P., García, H. P., Gianni, G. M., Weidmann, M. C., Folguera, A., et al. (2018). Thermo-mechanical analysis of the Andean lithosphere over the ChileanPampean flat-slab region. Journal of South American Earth Sciences, 87, 247-257. https://doi.org/10.1016/j.jsames.2017.09.036

Sánchez, M. A., García, H. P. A., Acosta, G., Gianni, G. M., Gonzalez, M. A., Ariza, J. P., et al. (2019). Thermal and lithospheric structure of the Chilean-Pampean flat-slab from gravity and magnetic data. In Horton, B., \& Folguera, A. (Eds.) Andean Tectonics (pp. 487-507). https://doi.org/10.1016/B978-0-12-816009-1.00005-8. Amsterdam, Netherlands: Elsevier

Saxena, S. K., \& Shen, G. (1992). Assessed data on heat capacity, thermal expansion, and compressibility for some oxides and silicates. Journal of Geophysical Research, 97(B13), 19813. https://doi.org/10.1029/92JB01555

Scarfi, L., \& Barberi, G. (2019). New insights on the tectonic structure of the Southern Central Andes-Western Argentina-from seismic tomography. Geology, Earth and Marine Sciences.

Schaeffer, A. J., \& Lebedev, S. (2013). Global shear speed structure of the upper mantle and transition zone. Geophysical Journal International, 194(1), 417-449. https://doi.org/10.1093/gji/ggt095

Scheck-Wenderoth, M., Cacace, M., Maystrenko, Y. P., Cherubini, Y., Noack, V., Kaiser, B. O., et al. (2014). Models of heat transport in the Central European Basin System: Effective mechanisms at different scales. Marine and Petroleum Geology, 55, 315331. https://doi.org/10.1016/j.marpetgeo.2014.03.009

Schurr, B., Rietbrock, A., Asch, G., Kind, R., \& Oncken, O. (2006). Evidence for lithospheric detachment in the central Andes from local earthquake tomography. Tectonophysics, 415(1), 203-223. https://doi.org/10.1016/j.tecto.2005.12.007

Sharples, W., Jadamec, M. A., Moresi, L. N., \& Capitanio, F. A. (2014). Overriding plate controls on subduction evolution. Journal of Geophysical Research: Solid Earth, 119(8), 6684-6704. https://doi.org/10.1002/2014JB011163

Sigismondi, M. E. (2012). Estudio de la deformación litosférica de la cuenca Neuquina: estructura termal, datos de gravedad y sísmica de reflexión. Retieved from https://bibliotecadigital.exactas.uba.ar/collection/tesis/document/tesis_n5361_Sigismo ndi. University of Buenos Aires

Sippel, J., Meeßen, C., Cacace, M., Mechie, J., Fishwick, S., Heine, C., et al. (2017). The Kenya rift revisited: insights into lithospheric strength through data-driven 3-D gravity and thermal modeling. Solid Earth, 8(1), 45-81. https://doi.org/10.5194/se-8-45-2017

Syracuse, E. M., van Keken, P. E., \& Abers, G. A. (2010). The global range of subduction zone thermal models. Special Issue on Deep Slab and Mantle Dynamics, 183(1), 73 90. https://doi.org/10.1016/j.pepi.2010.02.00

Sobolev, S. V., Zeyen, H., Stoll, G., Werling, F., Altherr, R., \& Fuchs, K. (1996). Upper mantle temperatures from teleseismic tomography of French Massif Central including effects of composition, mineral reactions, anharmonicity, anelasticity and partial melt. Earth and Planetary Science Letters, 139(1), 147-163. https://doi.org/10.1016/0012821X(95)00238-8

Spagnuolo, M. G., Orts, D. L., Gimenez, M., Folguera, A., \& Ramos, V. A. (2016). Payenia Quaternary flood basalts (southern Mendoza, Argentina): Geophysical constraints on their volume. Geoscience Frontiers, 7(5), 775-782.

https://doi.org/10.1016/j.gsf.2015.10.004 
Spooner, C., Scheck-Wenderoth, M., Cacace, M., Götze, H.-J., \& Luijendijk, E. (2020). The 3D thermal field across the Alpine orogen and its forelands and the relation to seismicity. Global and Planetary Change, 193, 103288. https://doi.org/10.1016/j.gloplacha.2020.103288

Steinberger, B., \& Calderwood, A. R. (2006). Models of large-scale viscous flow in the Earth's mantle with constraints from mineral physics and surface observations. Geophysical Journal International, 167(3), 1461-1481. https://doi.org/10.1111/j.1365-246X.2006.03131.x

Stixrude, L., \& Lithgow-Bertelloni, C.. (2005). Mineralogy and elasticity of the oceanic upper mantle: Origin of the low-velocity zone. Journal of Geophysical Research, 110(B3), B03204. https://doi.org/10.1029/2004JB002965

Tassara, A., \& Yáñez, G. (2003). Relación entre el espesor elástico de la litosfera y la segmentación tectónica del margen andino (15-47S). Andean Geology, 30(2), 159186.

Taylor, S. R. (1967). The origin and growth of continents. Tectonophysics, 4(1), 17-34. https://doi.org/10.1016/0040-1951(67)90056-X

Tesauro, M., Kaban, M. K., \& Cloetingh, S. A. P. L. (2009). How rigid is Europe's lithosphere? Geophysical Research Letters, 36(16). https://doi.org/10.1029/2009GL039229

Thompson, A. B., Schulmann, K., Jezek, J., \& Tolar, V. (2001). Thermally softened continental extensional zones (arcs and rifts) as precursors to thickened orogenic belts. Tectonophysics, 332(1), 115-141. https://doi.org/10.1016/S0040-1951(00)00252-3

Turcotte, D. L., \& Schubert, G. (2002). Geodynamics. Cambridge, England: Cambridge university press.

Uyeda, S., \& Watanabe, T. (1982). Terrestrial heat flow in western South America. Tectonophysics, 83(1-2), 63-70. https://doi.org/10.1016/0040-1951(82)90007-5

van Hunen, J., van den Berg, A. P., \& Vlaar, N. J. (2000). A thermo-mechanical model of horizontal subduction below an overriding plate. Earth and Planetary Science Letters, 182(2), 157-169. https://doi.org/10.1016/S0012-821X(00)00240-5

van Hunen, J., van den Berg, A. P., \& Vlaar, N. J. (2002). On the role of subducting oceanic plateaus in the development of shallow flat subduction. Tectonophysics, 352(3-4), 317-333.

van Hunen, J., van den Berg, A. P., \& Vlaar, N. J. (2004). Various mechanisms to induce present-day shallow flat subduction and implications for the younger Earth: a numerical parameter study. Physics of the Earth and Planetary Interiors, 146(1), 179194. https://doi.org/10.1016/j.pepi.2003.07.027

van Keken, P. E., Wada, I., Sime, N., \& Abers, G. A. (2019). Thermal Structure of the Forearc in Subduction Zones: A Comparison of Methodologies. Geochemistry, Geophysics, Geosystems, 20(7), 3268-3288. https://doi.org/10.1029/2019GC008334

Vilà, M., Fernández, M., \& Jiménez-Munt, I. (2010). Radiogenic heat production variability of some common lithological groups and its significance to lithospheric thermal modeling. Tectonophysics, 490(3-4), 152-164. https://doi.org/10.1016/j.tecto.2010.05.003

Wagner, L., Beck, S., Zandt, G., \& Ducea, M. (2006). Depleted lithosphere, cold, trapped asthenosphere, and frozen melt puddles above the flat slab in central Chile and Argentina. Earth and Planetary Science Letters, 245(1-2), 289-301. https://doi.org/10.1016/j.eps1.2006.02.014

Wagner, L. S., Beck, S., \& Zandt, G. (2005). Upper mantle structure in the south central Chilean subduction zone ( $30^{\circ}$ to $\left.36^{\circ} \mathrm{S}\right)$. Journal of Geophysical Research, 110(B1). https://doi.org/10.1029/2004JB003238 
Wangen, M. (1994). The blanketing effect in sedimentary basins. Basin Research, 7(4), $283-$ 298.

Ward, K. M., Porter, R. C., Zandt, G., Beck, S. L., Wagner, L. S., Minaya, E., \& Tavera, H. (2013). Ambient noise tomography across the Central Andes. Geophysical Journal International, 194(3), 1559-1573. https://doi.org/10.1093/gji/ggt166

Watts, A. B., \& Burov, E. B. (2003). Lithospheric strength and its relationship to the elastic and seismogenic layer thickness. Earth and Planetary Science Letters, 213(1), 113131. https://doi.org/10.1016/S0012-821X(03)00289-9

Wyllie, P. (1981). Plate tectonics and magma genesis. Geologische Rundschau, 70(1), 128153. https://doi.org/10.1007/BF01764318

Xu, Y., Shankland, T. J., Linhardt, S., Rubie, D. C., Langenhorst, F., \& Klasinski, K. (2004). Thermal diffusivity and conductivity of olivine, wadsleyite and ringwoodite to $20 \mathrm{GPa}$ and 1373 K. Physics of the Earth and Planetary Interiors, 143-144, 321-336. https://doi.org/10.1016/j.pepi.2004.03.005

Yáñez, G. A., Ranero, C. R., von Huene, R., \& Díaz, J. (2001). Magnetic anomaly interpretation across the southern central Andes (32-34 S): The role of the Juan Fernández Ridge in the late Tertiary evolution of the margin. Journal of Geophysical Research, 106(B4), 6325-6345.

Zapata, S., Sobel, E. R., Del Papa, C., \& Glodny, J. (2020). Upper Plate Controls on the Formation of Broken Foreland Basins in the Andean Retroarc Between $26^{\circ} \mathrm{S}$ and $28^{\circ} \mathrm{S}$ : From Cretaceous Rifting to Paleogene and Miocene Broken Foreland Basins. Geochemistry, Geophysics, Geosystems, 21(7).

https://doi.org/10.1029/2019GC008876 


\section{Supporting Information}
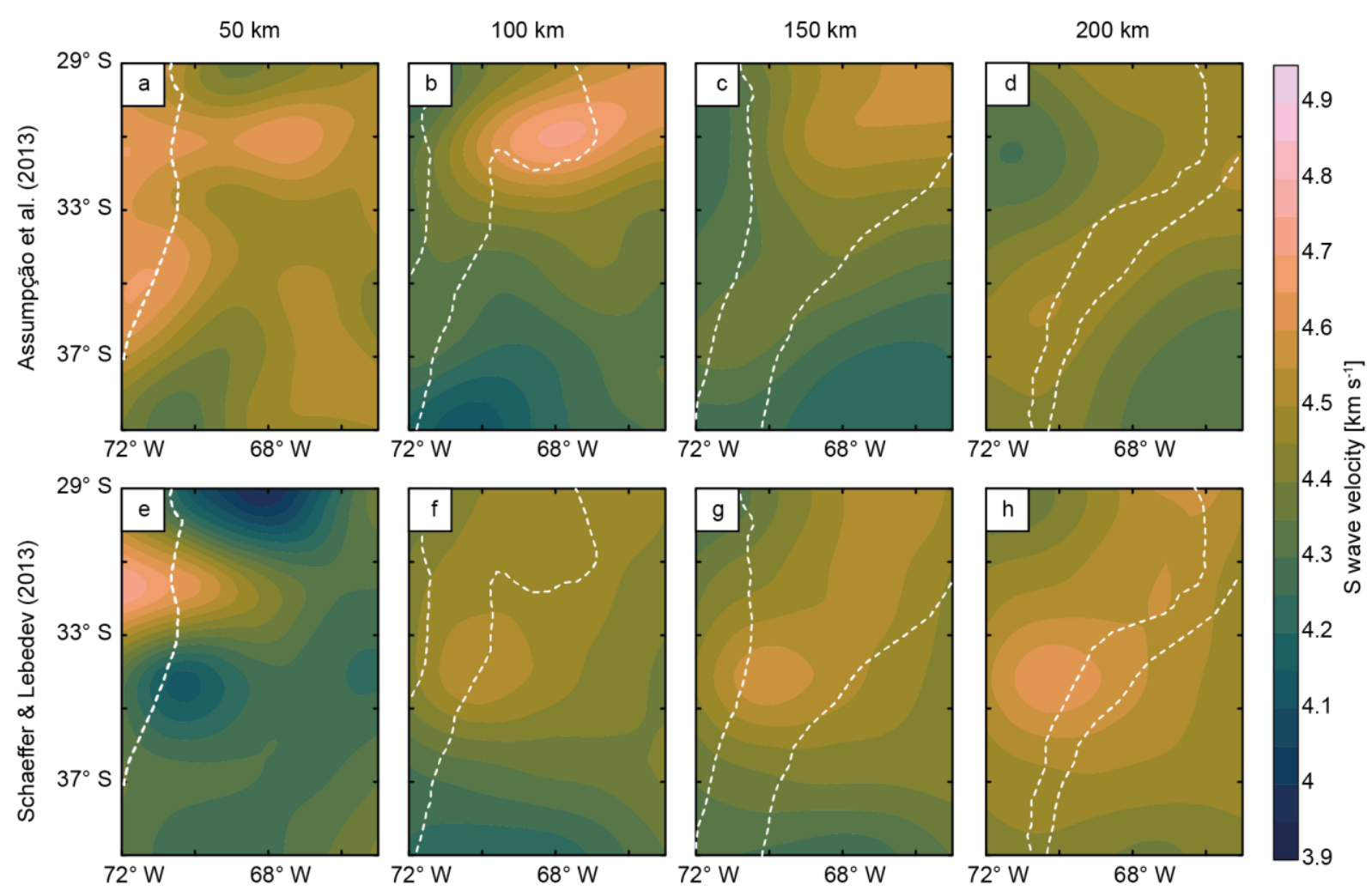

Figure S1. $S$ wave velocity $\left(\mathrm{V}_{\mathrm{s}}\right)$ distribution at depths of 50,100, 150 and $200 \mathrm{~km}$ from seismic tomography of (a-e) Assumpção et al. (2013) and (e-h) Schaeffer \& Lebedev (2013). Dashed lines indicate the top and bottom of the oceanic slab. There is a higher spatial correlation between high $\mathrm{V}_{\mathrm{s}}(>$ $4.4 \mathrm{~km} \mathrm{~s}^{-1}$ ) and the slab location in the tomography by Assumpção et al. (2013) compared to the tomography by Schaeffer \& Lebedev (2013).

\section{Text S1. Sensitivity analysis of the vs-to-T conversion}

Four models were defined to evaluate the sensitivity of the $\mathrm{v}_{\mathrm{s}}$-to-T conversion results to variations of different parameters or conversion method: mantle composition (spinel model), thermal expansion coefficient ( $\alpha$ model), attenuation (Q2 Model) and conversion method by Priestley and Mc Kenzie (2006).

To test the compositional effect on the model, the spinel lherzolite from Conceição et al. (2005) and Jalowitzki et al. (2010) was selected as alternative mantle composition (spinel model; Table 1 of main text). In contrast to the reference model, this composition is richer in clinopyroxene and iron and has spinel, instead of garnet, as aluminium phase. Within the compositional parameters, seismic velocities are most sensitive to the iron content, where an 
increase in the magnesium number $\mathrm{Mg} /(\mathrm{Mg}+\mathrm{Fe})$ by 10 is estimated to produce a velocity increase of 2-3\% (Cammarano et al., 2003; Goes et al., 2000).

Secondly, we assessed the effect of the temperature (T) dependence of the thermal expansion coefficient $\alpha$ on the resulting temperature distribution ( $\alpha \mathrm{T}$ model; Goes et al., 2000; Cammarano et al., 2003 based on Saxena \& Shen, 1992). Figure S2 shows the variation of $\alpha$ with $\mathrm{T}$ for different mantle minerals.

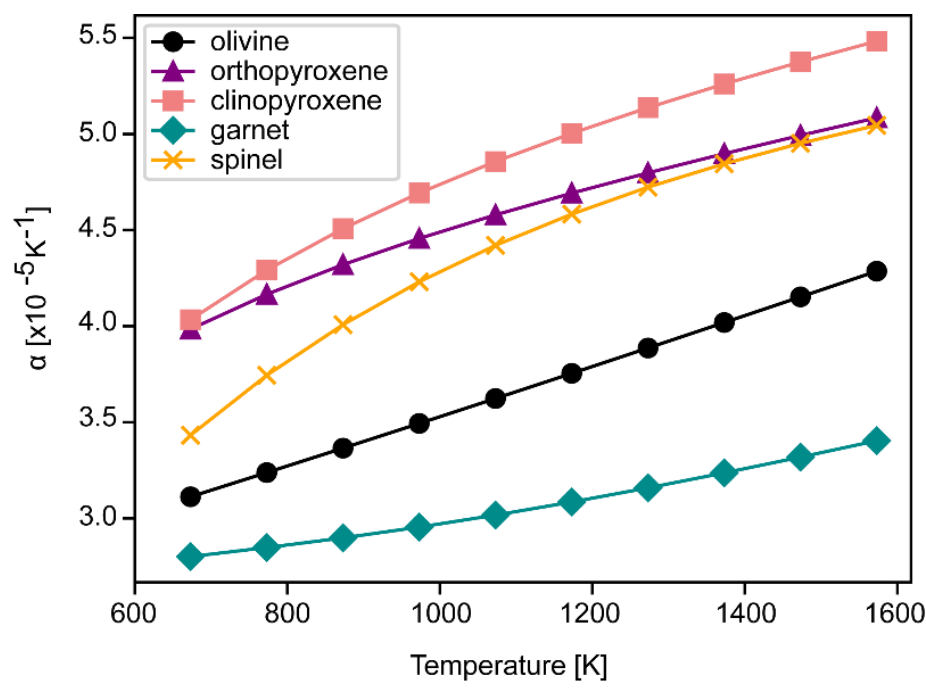

Figure S2. Variation of the thermal expansion coefficient $\alpha$ with temperature for the main mineral phases of the mantle. Values for olivine, orthopyroxene and garnet were taken from Cammarano et al. (2003). Values for spinel were taken from Goes et al. (2000). Both publications are based on experimental estimations of Saxena \& Shen (1992).

In a third stage, we used the parameters provided by Berckhemer et al. (1982) to investigate the effect of anelasticity $\mathrm{Q}\left(\mathrm{Q} 2\right.$ model; $\mathrm{a}=0.25, \mathrm{~A}=2 \mathrm{E}-4, \mathrm{H}=584 \mathrm{~kJ} \mathrm{~mol}^{-1}, \mathrm{~V}=$ $20 \mathrm{~cm}^{3} \mathrm{~mol}^{-1}$ ). This database is entirely derived from an experimental model for synthetic forsterite, in contrast to the attenuation parameters by Sobolev et al. (1996), which result from average values for a wide range of experiments. Therefore, the latter represents a more averaged Q model than the database of Berckhemer (1982; Goes et al. 2000). The Q2 model has a weaker attenuation than the reference model, thus the effect on anelasticity is smaller. Both models are considered to represent extreme values for the anelastic correction and, therefore, they allow for a rough estimation of the uncertainty in the $\mathrm{v}_{\mathrm{s}}$-to-T conversion due to unknowns related to Q (Shapiro et al., 2004). 
As a final step of the sensitivity analysis, we tested the alternative conversion method of Priestley \& McKenzie (2006; PM model), using the conversion tool VeloDT (Meeßen, 2020). In contrast to the Goes et al. (2000) mineral-physics-based approach, Priestley \& McKenzie (2006) derived an empirical relationship between $S$ wave and temperature, dependent on pressure but not on composition. Despite being calibrated mainly for oceanic lithosphere, the conversion was also applied to continental lithosphere using thermal models from mantle nodules in kimberlites, thus it was considered appropriate for our study area as well.
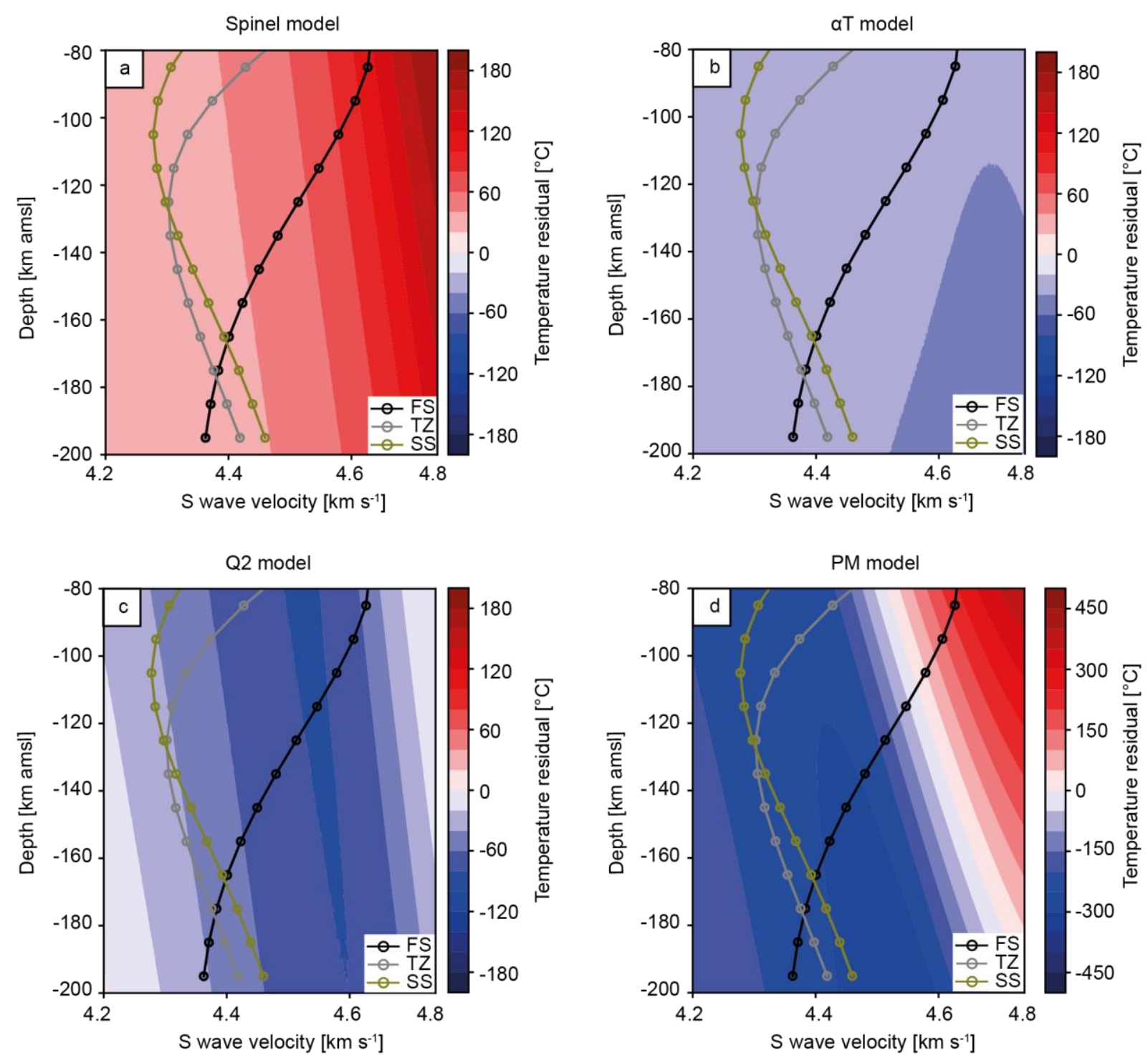

Figure S3. Residual temperature maps showing the difference between the reference model and the alternative configurations in the $\mathrm{v}_{\mathrm{s}}$-depth parameter space. a) Spinel model: mantle composition of spinel lherzolite (Conceição et al., 2005; Jalowitzki et al., 2010); b) $\alpha$ T model: T-dependent thermal expansion coefficient (Saxena \& Shen, 1992); c) Q2 model: attenuation parameters by Berckhemer et al. (1982); d) PM model: $\mathrm{v}_{\mathrm{s}}$-to-T conversion method of Priestley \& McKenzie (2006). 1-D $\mathrm{V}_{\mathrm{s}}$ profiles of the 
tomography of Assumpção et al. (2013) are overlain: FS = flat slab area; TZ = transition zone; SS = steep slab area.

Figure S3 shows the temperature residual (i.e. difference between the reference model and each alternative configuration tested) as a function of $v_{s}$ and depth. By relying on the Goes et al. (2000) approach, a modification of the mantle mineral composition yields up to $160^{\circ} \mathrm{C}$ difference at depths shallower than $100 \mathrm{~km}$ and high $\mathrm{V}_{\mathrm{s}}\left(4.6 \mathrm{~km} \mathrm{~s}^{-1}\right)$ with respect to the reference model (Fig. S3a). Variations in the expansion coefficient or seismic attenuation lead to temperature differences up to $80^{\circ} \mathrm{C}$ for $\mathrm{V}_{\mathrm{s}}$ of $4.6 \mathrm{~km} \mathrm{~s}^{-1}$ (Fig. S3b-c). In contrast, the method by Priestley and Mc Kenzie (2006) predicts higher temperatures for $\mathrm{V}_{\mathrm{s}}<4.6 \mathrm{~km} \mathrm{~s}-1$ than the reference model, up to $450^{\circ} \mathrm{C}$ higher for $\mathrm{V}_{\mathrm{s}}$ between 4.6 and $4.8 \mathrm{~km} \mathrm{~s}-1$ (Fig. S3d).

\section{Text S2. Thermal properties for the calculation of the steady-state conductive thermal field}

The assignment of thermal properties to the units of the structural model of Rodriguez Piceda et al. (2020) was done according to the comparison between gravity-constrained densities (Rodriguez Piceda et al., 2020) and mean $P$ wave velocities (Vp, Araneda et al., 2003; Contreras-Reyes et al, 2008; Marot et al., 2014; Scarfi \& Barbieri, 2019), combined with rock property compilations (Brocher, 2005; Christensen \& Mooney, 1995).

For the sedimentary layers, based on a mean density of $2350 \mathrm{~kg} \mathrm{~m}^{-3}$ (Rodriguez Piceda et al., 2020) and a mean velocity of $4.6 \mathrm{~km} \mathrm{~s}^{-1}$ (Araneda et al., 2013), we assigned a siliciclastic composition (Brocher, 2005). Thus, we attributed to both sedimentary units a thermal conductivity of $2 \mathrm{Wm}^{-1} \mathrm{~K}^{-1}$ (Čermák \& Rybach, 1982) and a radiogenic heat production of 1 $\mu \mathrm{Wm}^{-3}$ (Vilà et al., 2010), consistent with this lithology.

The physical properties of the upper crust (density of $2800 \mathrm{~kg} \mathrm{~m}^{-3}$; $\mathrm{Vp}$ of $6.3 \mathrm{~km} \mathrm{~s}^{-1}$ ) are indicative of diorites (Christensen \& Mooney, 1995). According to this lithology, the thermal conductivity was set to $3.4 \mathrm{Wm}^{-1} \mathrm{~K}^{-1}$ (Čermák \& Rybach, 1982) and the heat production to $2 \mu \mathrm{Wm}^{-3}$ (Vilà et al., 2010).

In the case of the lower crust, its composition is not precisely determined thoughout the entire region, apart from a modeled density of $3100 \mathrm{~kg} \mathrm{~m}^{-3}$ (Rodriguez Piceda et al., 2020), a mean Vp of $6.76 \mathrm{~km} \mathrm{~s}^{-1}$ (Marot et al., 2014; Pesicek et al., 2012; Scarfi \& Barbieri 2019) and 
the occurrence of partial eclogitization suggested by several studies in the region of the flat slab (e.g. Alvarado et al., 2007, 2009; Ammirati et al. 2013, 2015, 2018; Gilbert et al., 2006; Marot et al., 2014). The comparison of these physical properties with the compilation of Christensen \& Mooney (1995) points to a mafic granulite composition. Conforming to this rock type, we used a lower crustal thermal conductivity of $2.5 \mathrm{Wm}^{-1} \mathrm{~K}^{-1}$ (Čermák \& Rybach, 1982) and a heat production of $0.4 \mu \mathrm{Wm}^{-3}$ (Hasterok \& Chapman, 2011).

For the shallow oceanic crust, a density of $2900 \mathrm{~kg} \mathrm{~m}^{-3}$ (Rodriguez Piceda et al., 2020) and a mean Vp of $6.7 \mathrm{~km} \mathrm{~s}^{-1}$ (Araneda et al., 2003; Contreras Reyes et al., 2008) suggest that this layer is represented by a basaltic composition (Chirstensen \& Mooney, 1995). Thus, we chose a thermal conductivity of $1.8 \mathrm{Wm}^{-1} \mathrm{~K}^{-1}$ (Čermák \& Rybach, 1982) and radiogenic heat production of $0.35 \mu \mathrm{Wm}^{-3}$ (Vilà et al., 2010), consistent with this lithology. For the deep oceanic crust, based on a modeled density of $3200 \mathrm{~kg} \mathrm{~m}^{-3}$ and a mean Vp of $7.1 \mathrm{~km} \mathrm{~s}^{-1}$ (Araneda et al., 2003; Contreras Reyes et al., 2008), we assumed an eclogitic composition (Christensen \& Mooney, 1995). Hence, we assigned to this layer a thermal conductivity of $2.87 \mathrm{Wm}^{-1} \mathrm{~K}^{-1}(\mathrm{He}$ et al., 2008) and a radiogenic heat production of $0.25 \mu \mathrm{Wm}^{-3}$ (Vilà et al., 2010).

Lastly, for the mantle layers, based on the average density of $3360 \mathrm{~kg} \mathrm{~m}^{-3}$ (oceanic lithospheric mantle) and $3340 \mathrm{~kg} \mathrm{~m}^{-3}$ (continental lithospheric/oceanic sub-lithospheric mantle), we assigned a composition of moderately depleted lherzolite (Rodriguez Piceda et al., 2020). This is also coherent with geochemical data of mantle xenoliths (Bertotto et al., 2003), $\mathrm{V}_{\mathrm{s}}$ of 4.6-4.7 $\mathrm{km} \mathrm{s}^{-1}$ (Wagner et al., 2005) and $\mathrm{Vp} / \mathrm{V}_{\mathrm{s}}$ ratios of 1.75-1.77 (Marot et al., 2014). Accordingly, we set a mantle radiogenic heat production of $0.01 \mu \mathrm{Wm}^{-3}$ (Vilà et al., 2010). The thermal conductivity of the mantle was determined based on the empirical relationship of $\mathrm{Xu}$ et al. (2004). This expression quantifies the $\mathrm{P}$ (pressure)-T(temperature) dependency of the thermal conductivity $\lambda$ of olivine from thermal diffusivity measurements at pressures up to 20 $\mathrm{GPa}$ and temperatures up to $1373 \mathrm{~K}$ and is described as:

$\lambda=4.10\left(\frac{298}{\mathrm{~T}}\right)^{0.493}(1+0.032 \mathrm{P})$

where $\mathrm{T}$ is in $\mathrm{K}$ and $\mathrm{P}$ is in $\mathrm{GPa}$.

Figure S4a shows the variation of thermal conductivity with $\mathrm{P}$ and $\mathrm{T}$ for the upper mantle (up to $10 \mathrm{GPa}$ and $1750 \mathrm{~K}$ ), overlain with 3 representative geotherms of the study area derived from the $\mathrm{v}_{\mathrm{s}}$-to-T conversion (see Section 2.1 of the main text). Overall, thermal conductivity decreases with increasing temperature and decreasing pressure. The largest variation of $\lambda$ occurs at low temperatures $(<750 \mathrm{~K})$. Figure $\mathrm{S} 4 \mathrm{~b}$ depicts the histogram of thermal conductivities for 
the P-T range of the results of $\mathrm{v}_{\mathrm{s}}$-to-T conversion. For this range, the mean value of $\lambda$ is $2.24 \mathrm{Wm}^{-1} \mathrm{~K}^{-1}$ with a standard deviation of $0.12 \mathrm{Wm}^{-1} \mathrm{~K}^{-1}$. Therefore, the variations of $\lambda$ are sufficiently small to consider taking a constant value of $2.24 \mathrm{Wm}^{-1} \mathrm{~K}^{-1}$ as a valid assumption for the entire modeled P-T range of the lithospheric mantle.
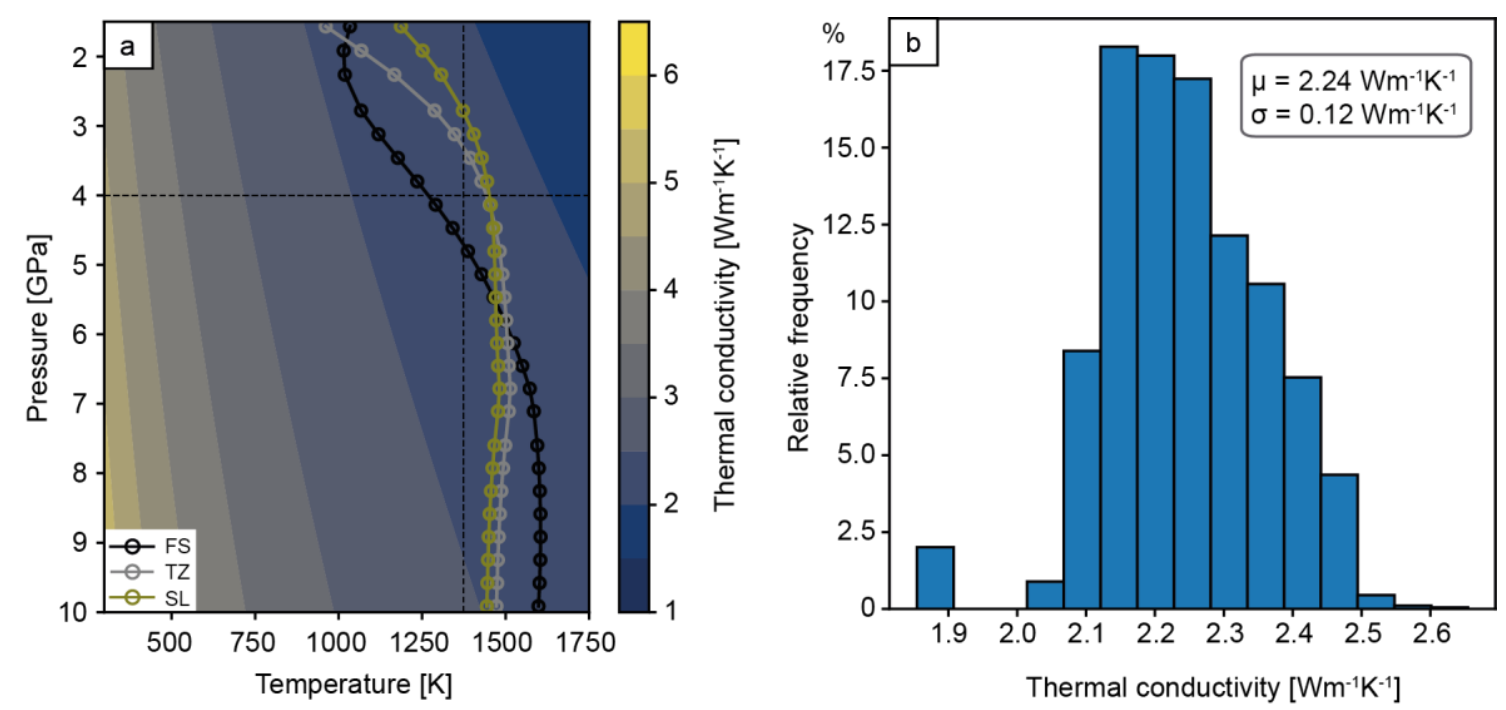

Figure S4. (a) Thermal conductivity $\mathrm{v}_{\mathrm{s}}$. pressure and temperature according to eq. 1 (Xu et al., 2004) overlain with 1-D geotherms of the study area. FS= Flat slab area, TZ=Transition zone, SS=Steep slab area. (b) Histogram of thermal conductivity calculated for the (P-T) range of the results of the $\mathrm{V}_{\mathrm{s}}$-to-T conversion (Section 2.1 of main text; Goes et al., 2000; Meeßen, 2017). $\mu$ is the mean value and $\sigma$ the standard deviation.

Text S3. Sensitivity analysis of the steady-state conductive thermal modelling

We performed a sensitivity analysis of the modeled temperatures to variations of the thermal properties (thermal conductivity $\lambda$ and radiogenic heat production $\mathrm{S}$ ) of the units composing the structural model. To this end, we carried out a steady-state conductive simulation on alternative configurations of the final structural model, varying one thermal parameter at a time. The imposed variations of each property are based on the range of its natural variability according to the composition of each unit (Table S1, Carter and Tsenn, 1987; Čermák \& Rybach, 1982; Hasterok \& Chapman, 2011; He et al., 2008; Russell et al. , 2001; Majorowicz et al. ,2019; Vilà et al., 2010; Xu et al., 2004). Figure S5 displays the temperature difference between the preferred model described in the main text and each alternative configuration at depths of 10 and $30 \mathrm{~km}$ bmsl. A preliminary analysis of these depth slices shows that the greatest temperature differences occur when varying the radiogenic heat production of the upper crust. However, since perturbations of different magnitude are imposed to each thermal property, in order to properly compare the results, we compute a normalization factor $\mathrm{f}$ by dividing the maximum induced variation in temperature by the relative variation of the thermal property that induced such temperature perturbation (Table S1). This factor quantifies how the temperature changes according 
to variations in the predefined thermal properties of the units. A comparison of the factor $f$ corresponding to the thermal conductivity and the radiogenic heat production of each unit is depicted in Figure S6. Contrary to our preliminary analysis, this approach indicates that temperatures are most sensitive to perturbations in the thermal conductivity of the upper continental crystalline crust and the mantle ( $\mathrm{f}=10.9$ $\left.{ }^{\circ} \mathrm{C} / \%\right)$. 
Table S1. Summary of results from sensitivity analysis of the steady state conductive thermal modelling to variations in thermal conductivity $\lambda$ and radiogenic heat production $\mathrm{S}$. The factor $\mathrm{f}$ is calculated by dividing the absolute value of the maximum $\Delta \mathrm{T}$ (i.e., temperature difference between final and alternative models) by the relative variation of the thermal property

\begin{tabular}{|c|c|c|c|c|c|c|c|}
\hline \multirow{2}{*}{\multicolumn{2}{|c|}{ Layers }} & \multicolumn{3}{|c|}{ Thermal conductivity $\lambda$} & \multicolumn{3}{|c|}{ Radiogenic heat production $S$} \\
\hline & & $\begin{array}{l}\lambda\left[\mathrm{Wm}^{-1} \mathbf{K}^{-1}\right] / \text { Absolute } \lambda \\
\text { variation }\left[\mathbf{m}^{-1} \mathbf{K}^{-1}\right] / \\
\text { Relative } \lambda \text { variation }(\%)\end{array}$ & $\begin{array}{l}\text { Maximum } \Delta T, \\
\text { abs. value }\left({ }^{\circ} \mathbf{C}\right)\end{array}$ & $\begin{array}{l}\text { Factor f } \\
{\left[\% /{ }^{\circ} \mathbf{C}\right]}\end{array}$ & 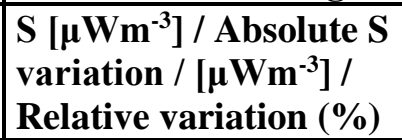 & $\begin{array}{l}\text { Maximum } \Delta T, \\
\text { abs.value }(k m)\end{array}$ & $\begin{array}{l}\text { Factor f } \\
{\left[\% /{ }^{\circ} \mathbf{C}\right]}\end{array}$ \\
\hline \multicolumn{2}{|c|}{ Continental/oceanic sediments } & $1.81^{1} /-0.19 / 9.5$ & 12 & 1.2 & $0.12^{2} /-0.88 / 87.7$ & 5 & 0.06 \\
\hline \multirow{2}{*}{\multicolumn{2}{|c|}{ Upper continental crystalline crust }} & $1.72^{1} /-1.68 / 49$ & 65 & 1.3 & $0.25^{2} /-1.75 / 87.4$ & 200 & 2.30 \\
\hline & & $4.14^{1} /+0.74 / 21.8$ & 237 & 10.9 & $3.8 /+1.8 / 90$ & 206 & 2.30 \\
\hline \multicolumn{2}{|c|}{ Lower continental crystalline crust } & $2.10^{3} /-0.4 /-16$ & 48 & 3 & $0.20^{5} /-0.2 /-50$ & 39 & 0.78 \\
\hline \multirow[t]{3}{*}{ Oceanic plate } & Shallow crust & $5.33^{1} /+3.53 / 196$ & 63 & 0.30 & $1.2^{2} /+0.85 / 243$ & 62 & 0.26 \\
\hline & \multirow{2}{*}{ Deep crust } & $2.20^{6} /-0.67 /-23.3$ & 34 & 1.46 & $0.02^{2} /-0.23 / 90.4$ & 33 & 0.37 \\
\hline & & $3.60^{6} /+0.73 / 25.4$ & 32 & 1.26 & $0.70^{2} /+0.45 / 180$ & 42 & 0.23 \\
\hline \multirow{2}{*}{\multicolumn{2}{|c|}{$\begin{array}{l}\text { Continental and Oceanic lithospheric } \\
\text { mantle/Oceanic sub-lithospheric } \\
\text { mantle }\end{array}$}} & $2.10^{7} /-0.14 /-6.25$ & 38 & 6.08 & $0.00^{2} /-0.01 / 100$ & 41 & 0.41 \\
\hline & & $3.30^{8} /+1.06 / 47.3$ & 84 & 1.78 & $0.80^{2} /+0.79 / 7900$ & 102 & 0.01 \\
\hline
\end{tabular}

${ }^{1}$ Čermák \& Rybach (1982); ${ }^{2}$ Vilà et al. (2010); ${ }^{3}$ Majorowicz et al. (2019); ${ }^{4}$; Carter and Tsenn (1987) ${ }^{5}$ Hasterok \& Chapman (2011); ${ }^{6}$ He et al. (2008); ${ }^{7}$ Xu et al.

(2004); ${ }^{8}$ Russell et al. (2001) 

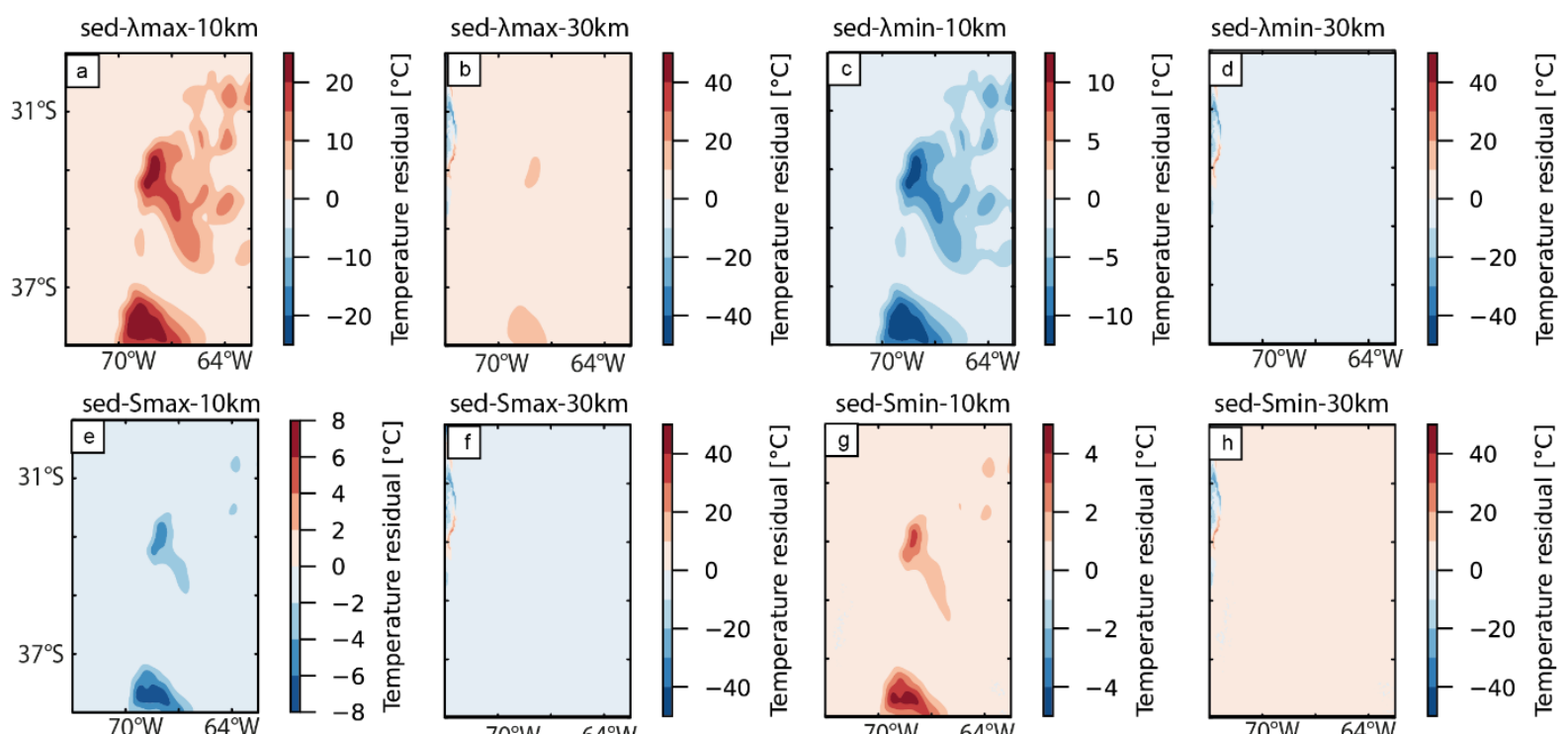

sed-Smax-30km
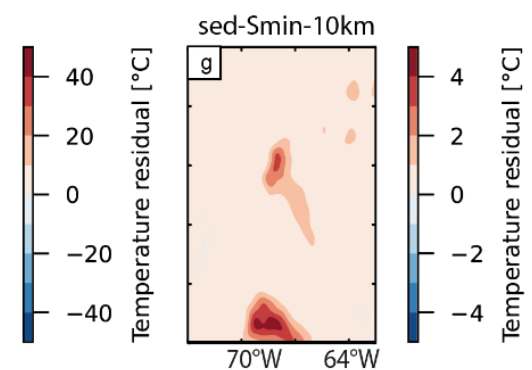

sed-Smin-30km
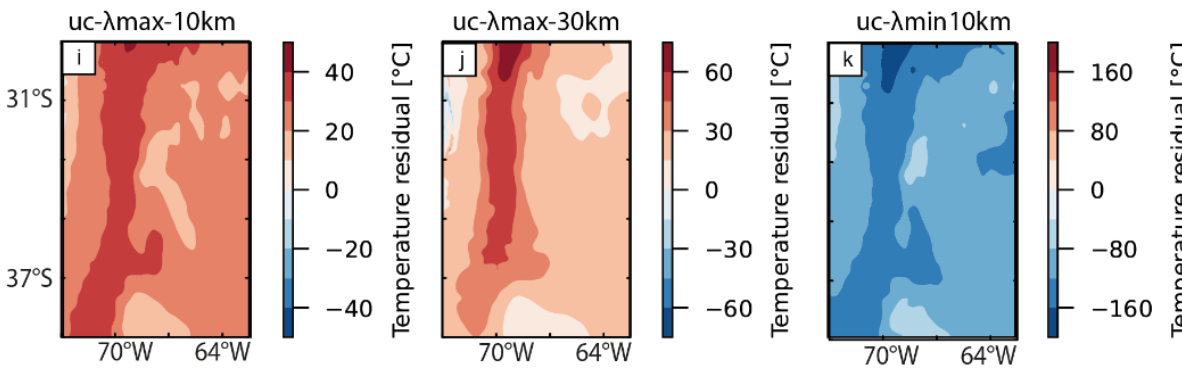

uc- $\lambda$ min-30km
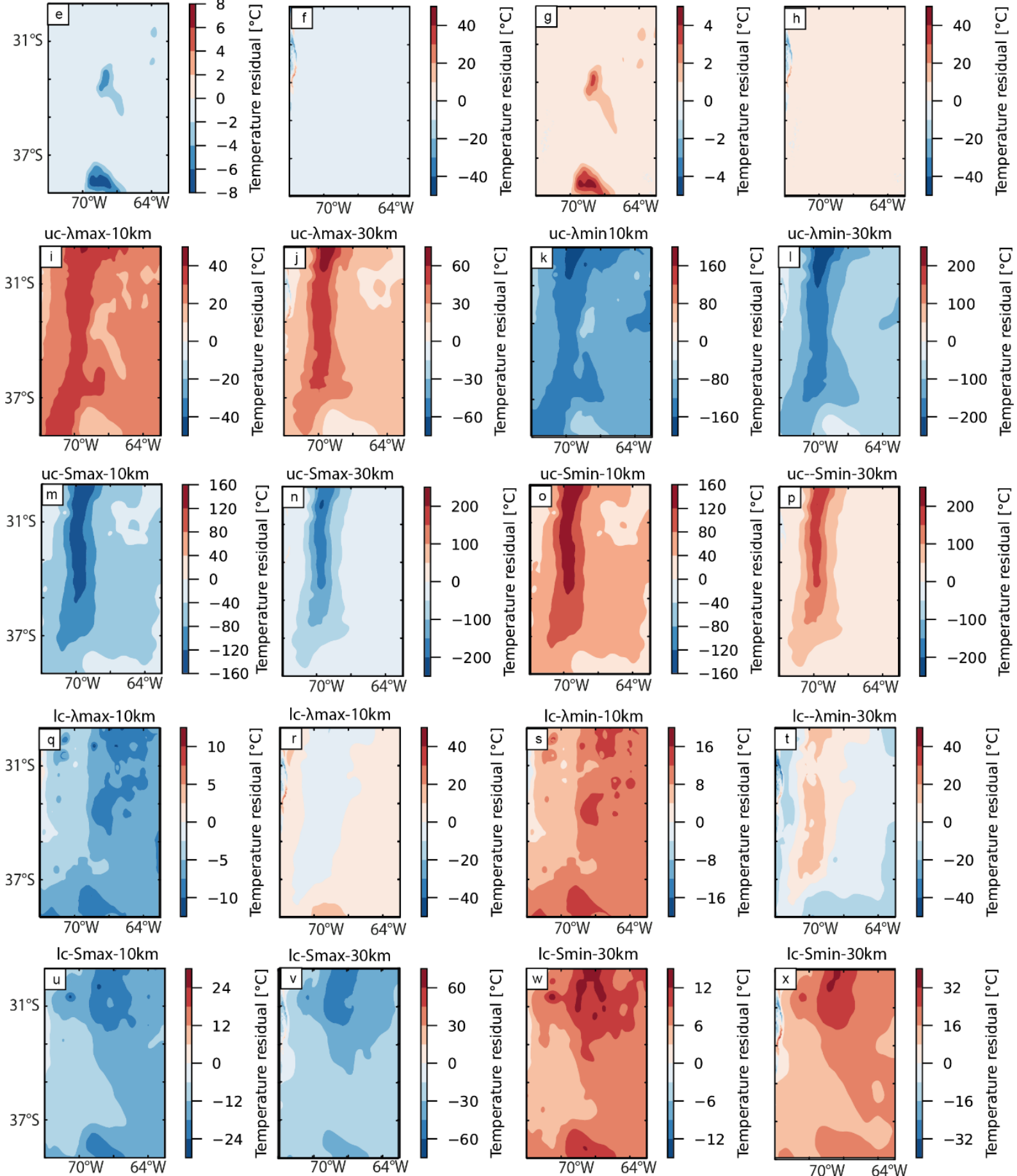
3 Figure S5. Slices at depths of 10 and $30 \mathrm{~km}$ bmsl (below mean sea level) showing the temperature 4 residual (i.e. difference between the temperature fields of the final steady-state conductive model and 5 alternative configurations tested in the sensitivity analysis) for the thermal properties of the sediments 6 and the continental crystalline crust. $\lambda=$ bulk thermal conductivity; $S=$ radiogenic heat production.

7 Sed=sediments; uc=upper continental crystalline crust; lc=lower continental crystalline crust. 8 

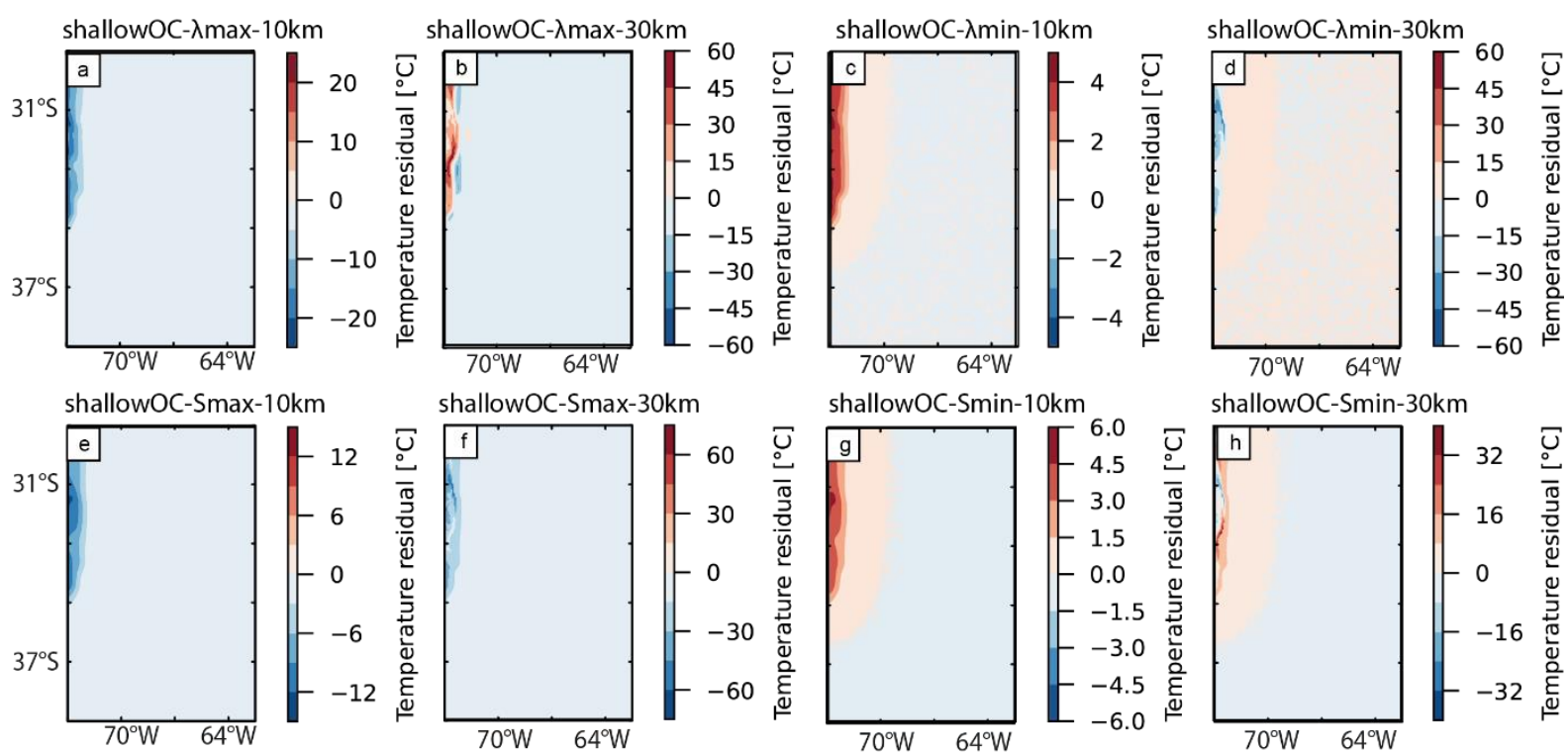

shallowOC-Smin-10km

shallowOC-Smin-30km
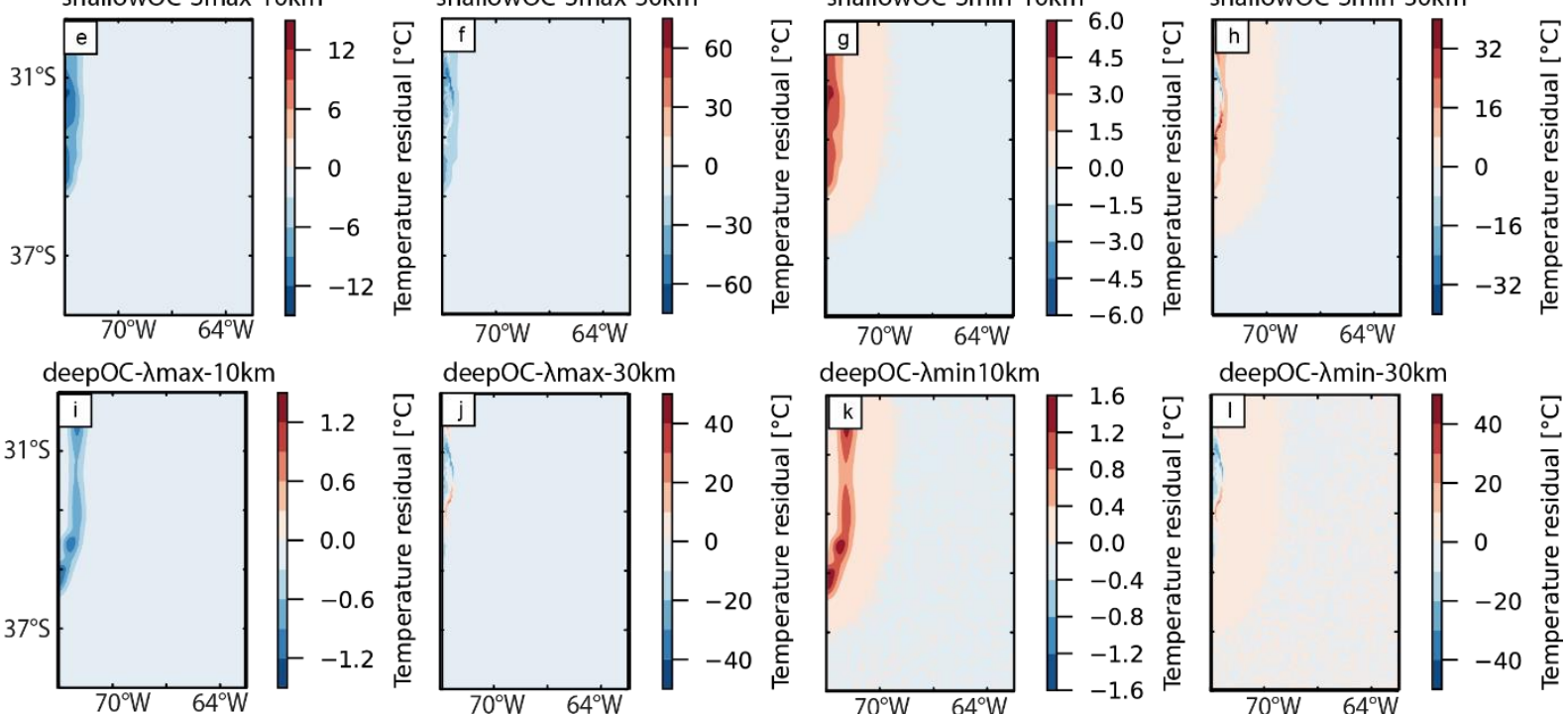

deepOC- $\lambda \min 10 \mathrm{~km}$
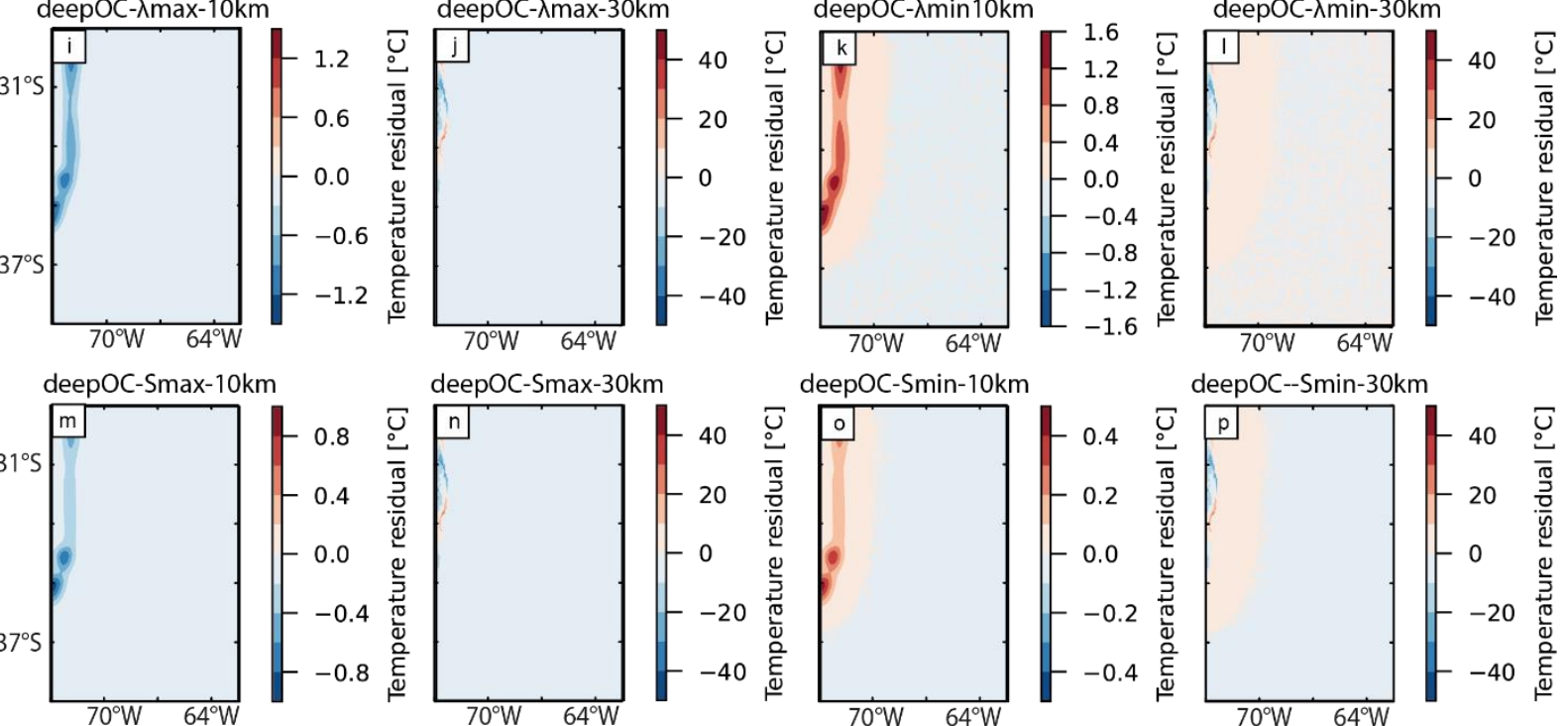

deepOC-Smax-30km

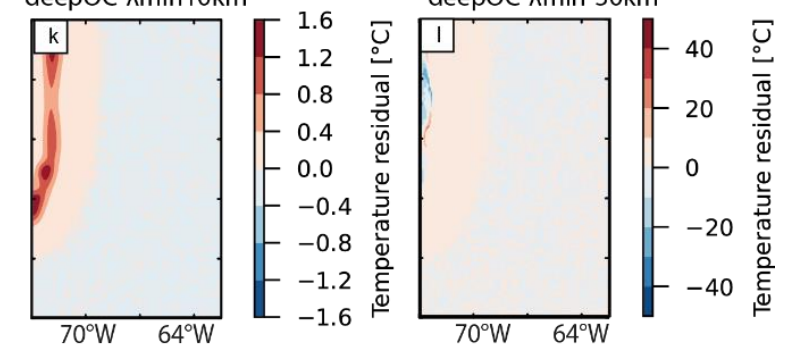

eepOC--Smin-30km
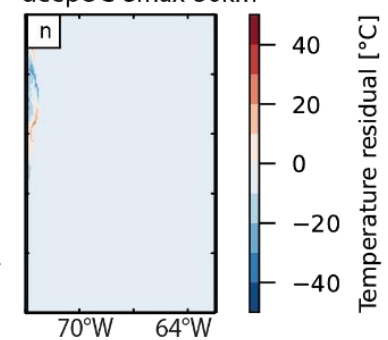

deepOC-Smin-10km
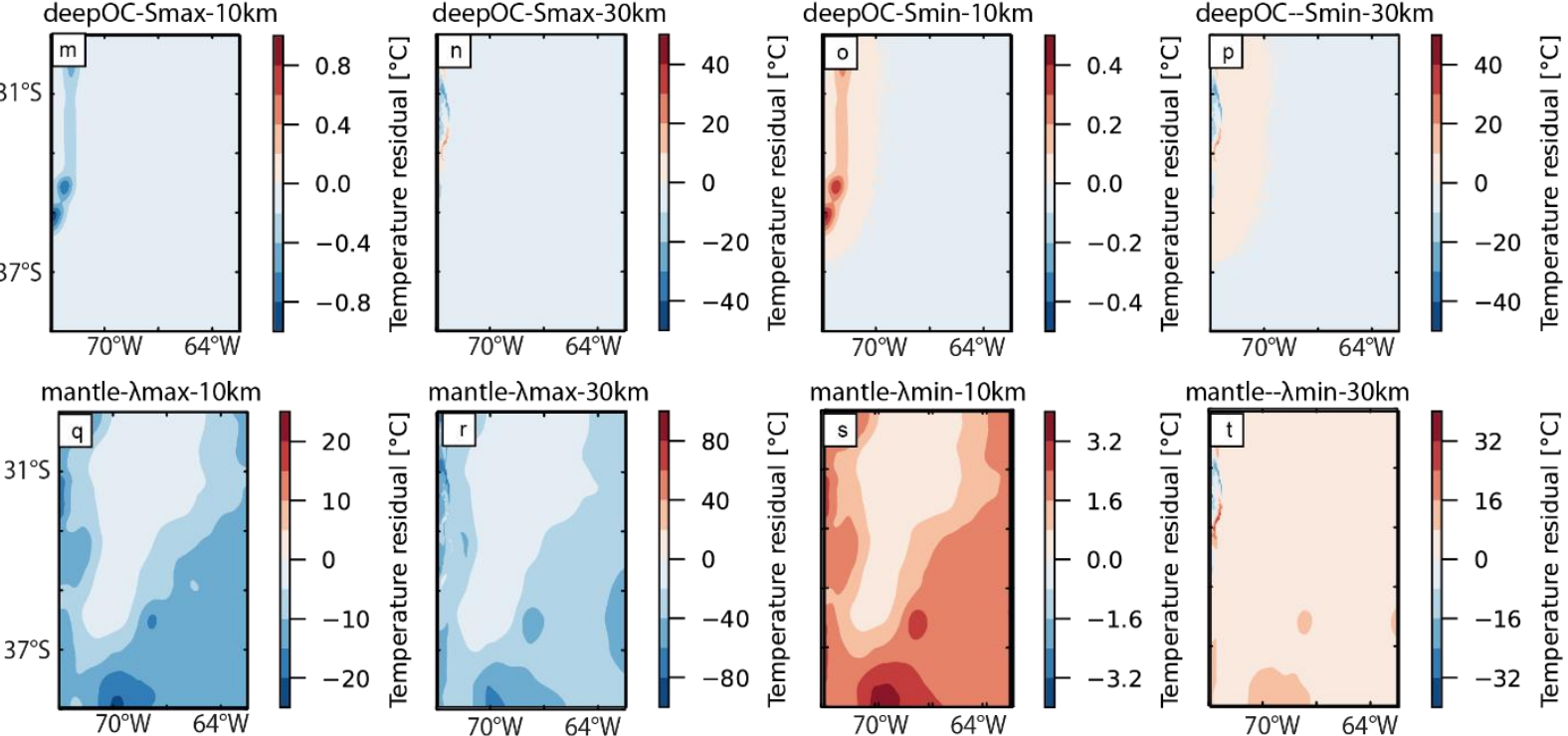

mantle- $\lambda$ min-10km
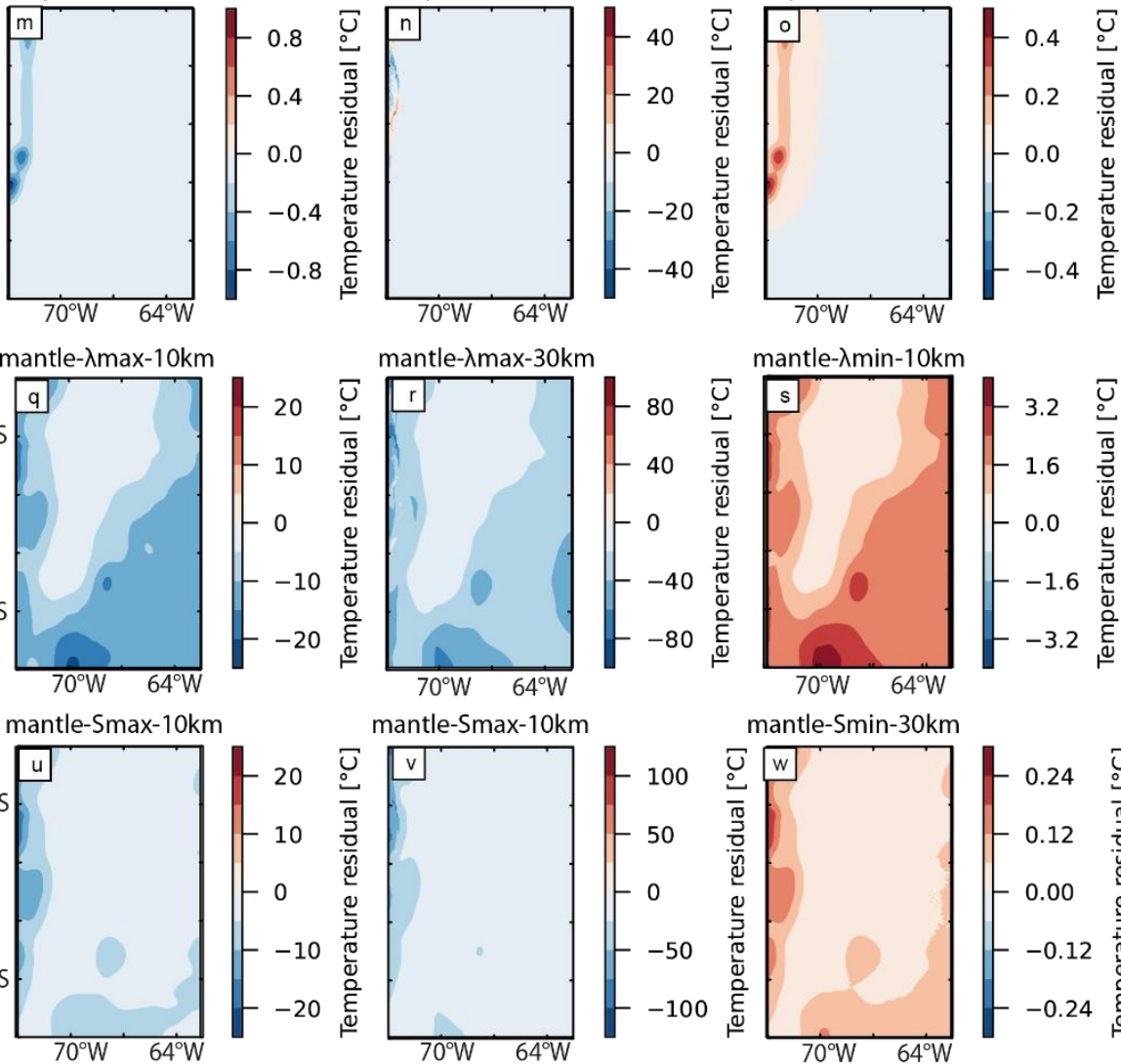

mantle-- $\lambda$ min-30km
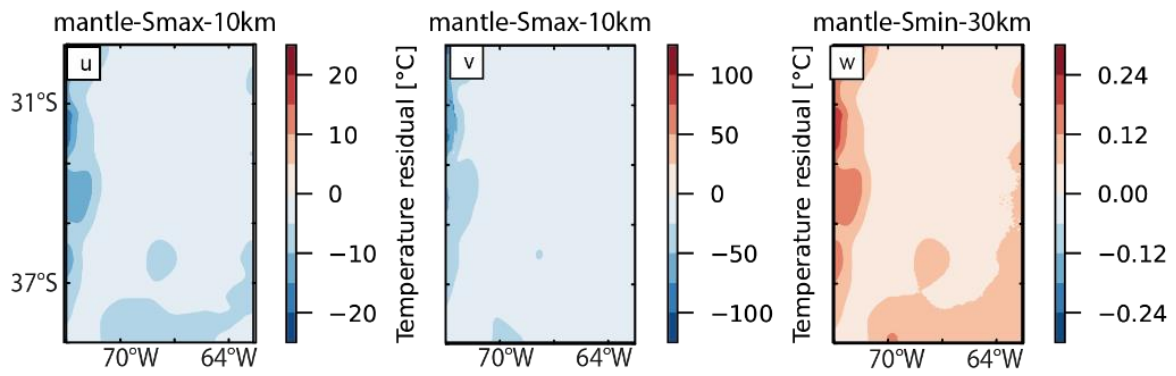

mantle-Smin-30km
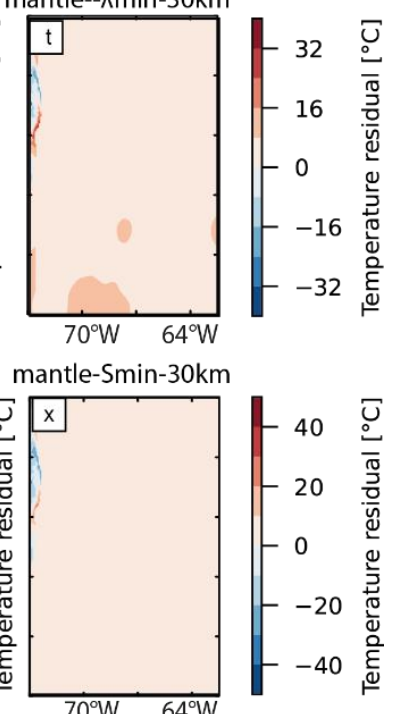
11 Figure S5 (cont). Slices at depths of 10 and $30 \mathrm{~km} \mathrm{bmsl} \mathrm{(below} \mathrm{mean} \mathrm{sea} \mathrm{level)} \mathrm{showing} \mathrm{the} \mathrm{temperature}$

12 residual for thermal properties of the oceanic crust (a-p) and the mantle $(q-x)$. shallowOC $=$ shallow

13 oceanic crust; deepOC=deep oceanic crust.

14

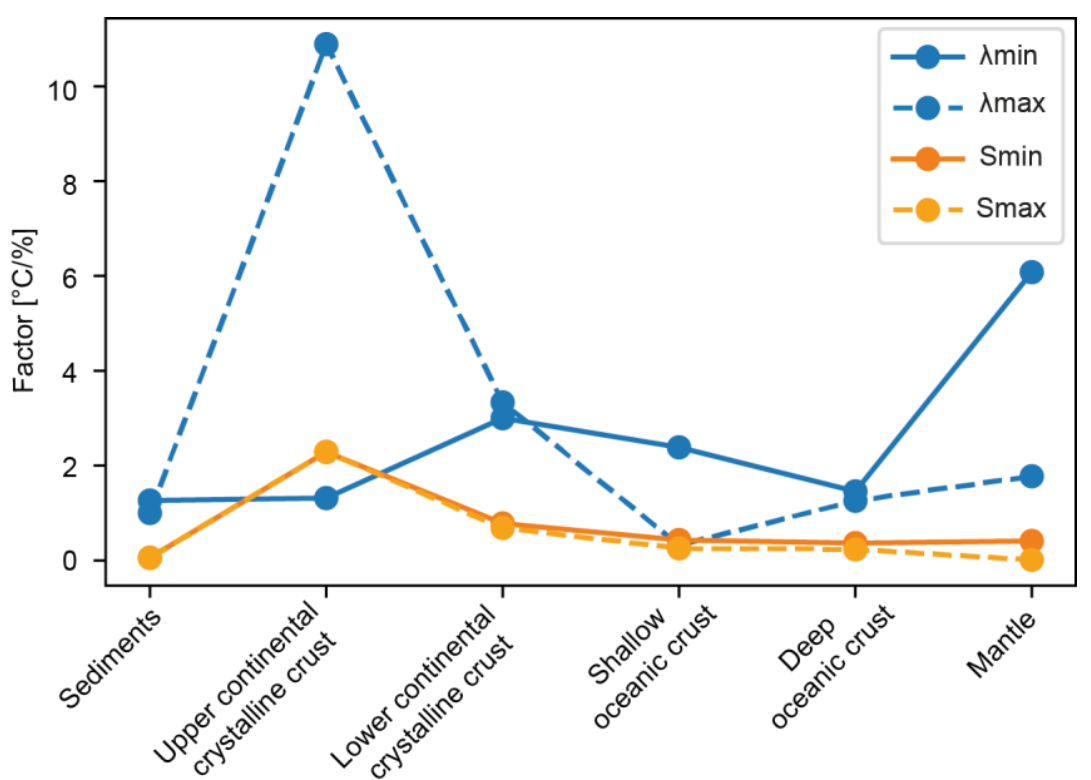

16 Figure S6. Variation of the sensitivity factor $f$ corresponding to the variation of the thermal properties 17 of the model units. $\lambda=$ bulk thermal conductivity; $\mathrm{S}=$ radiogenic heat production.

\section{Text S4. Upper thermal boundary condition}

20 For the upper thermal boundary condition in the continental domain, we considered the yearly average

21 surface temperature from 1981 to 2020, provided by the ERA-5 land database (Copernicus Climate

22 Change Service, 2019). In the oceanic domain, we used a constant temperature of $4{ }^{\circ} \mathrm{C}$, which is an

23 average estimate at sea floor (Pawlowicz, 2013). Figure S7 illustrates the upper thermal boundary

24 condition across the entire region, with continental temperatures ranging from $-1{ }^{\circ} \mathrm{C}$ in the Andean

25 orogen to $30^{\circ} \mathrm{C}$ in the forearc and foreland areas. 


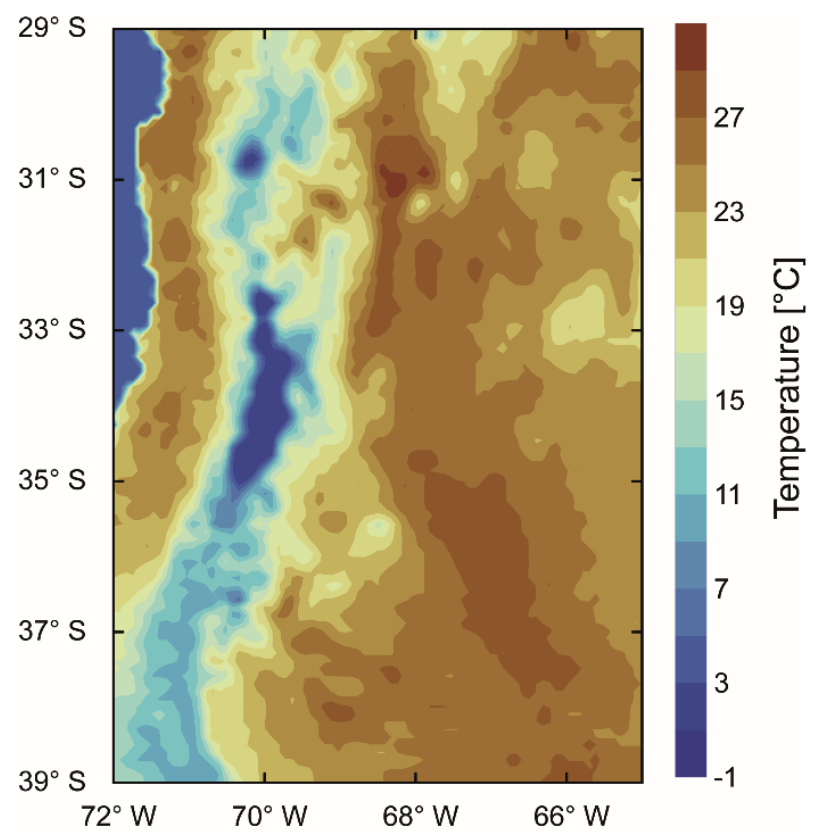

28 Figure S7. Temperature distribution at the surface obtained from the ERA-5 land data set (Copernicus

29 Climate Change Service, 2019) and assuming a constant value of $4^{\circ} \mathrm{C}$ for the oceanic domain. This was

30 used as the upper thermal boundary condition of the conductive steady-state model to estimate crustal

31 and uppermost mantle temperatures.

\section{Text S5. Transient thermal modelling approach}

34 S5.1. Advective thermal modelling of the subduction interface

In a first modelling stage, we computed the thermal evolution of the subduction interface

36 in 7 Ma due to advection and conduction with the Finite Element numerical simulator LYNX

37 (Jacquey \& Cacace, 2019, 2020). We used a 2D mesh that represents a horizontal projection of

38 the subduction interface with a horizontal resolution of $5 \mathrm{~km}$ and an extension of $1400 \mathrm{~km}$ by

$391400 \mathrm{~km}$. Temperatures are computed in LYNX by solving the energy equation, which accounts

40 for both heat transfer by conduction and by advection of solid material. If we neglect the effect

41 of radiogenic heat production and shear heating, the equation reads as follows:

$42 \frac{\partial T}{\partial t}+v \cdot \nabla T-\nabla\left(\frac{\lambda}{c_{p \cdot \rho}} \cdot \nabla T\right)=0(2)$

44 where $\mathrm{T}$ is temperature, $\mathrm{t}$ is time, $v$ is the solid velocity, $\lambda$ is the thermal conductivity, $\mathrm{C}_{\mathrm{p}}$ is the 45 heat capacity and $\rho$ is the bulk density. $\lambda$ was set to $1.8 \mathrm{Wm}^{-1} \mathrm{~K}^{-1}, \rho$ to $2900 \mathrm{kgm}^{-3}$ and $\mathrm{C}_{\mathrm{p}}$ to $461200 \mathrm{~m}^{2} \mathrm{~s}^{-1}$, which is consistent with a basaltic composition representative of the top slab 
47 (Petitjean et al., 2006). As $v$ we used the absolute velocity of the Nazca Plate at present-day $48\left(v_{\mathrm{n}}=0.04 \mathrm{myr}^{-1}\right.$, Sdrolias \& Müller, 2006) projected horizontally by applying the following

49 equation:

$50 v=\cos \propto \cdot v_{n}(3)$

51 where $\alpha$ is the subduction angle of the oceanic plate extracted from the 3D structural model 52 (Rodriguez Piceda et al., 2020). $v$ was set to $0 \mathrm{myr}^{-1}$ at the nodes where the depth of the 53 subduction interface is $>200 \mathrm{~km}$ bmsl (i.e., base of the steady-state conductive thermal model 54 of the main text). The velocity field is shown in Figure S8a. The model was initialized with the 55 temperature distribution at the subduction interface extracted from the $S$ wave tomography 56 (Figure S8b, Assumpção et al., 2013).

57
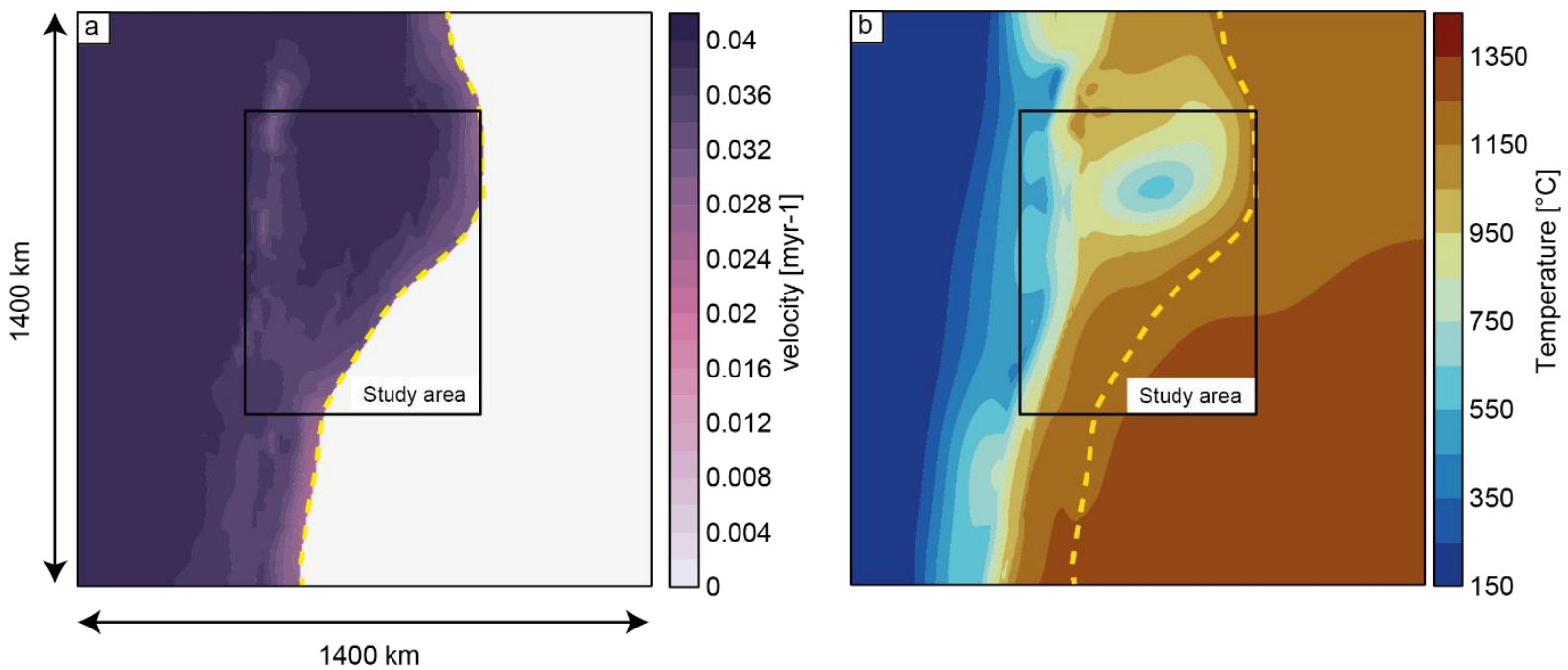

59 Figure S8. Set up of the advective-conductive thermal model of the subduction interface. (a) absolute

60 plate velocity of the oceanic plate projected horizontally according to eq. 3 . $v$ was set to $0 \mathrm{cmyr}^{-1}$ at the

61 nodes right of the dashed yellow line since the slab there is deeper than $200 \mathrm{~km} \mathrm{bmsl.;} \mathrm{(b)} \mathrm{initial}$

62 temperature distribution from the $S$ wave tomography of Assumpção et al. (2013). The black rectangle

63 bounds the study area.

64

65

Figure S9 shows the W-E progression of the cold thermal front along the subduction 66 interface after (a) $2 \mathrm{Ma}$, (b) $5 \mathrm{Ma}$ and (c) $7 \mathrm{Ma}$ of model run. 

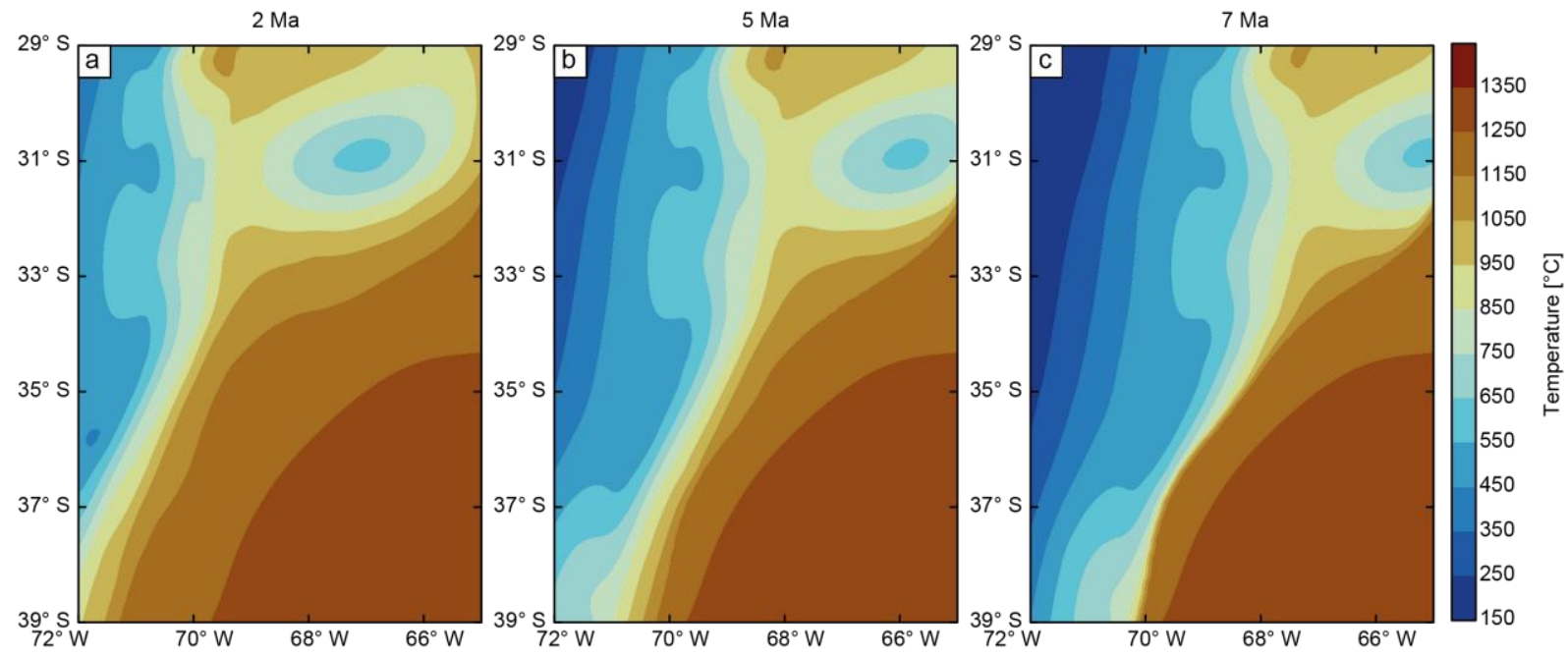

68 Figure S9. Thermal evolution of the subduction interface in the study area after (a) $2 \mathrm{Ma}$, (b) $5 \mathrm{Ma}$ and

69 (c) 7 Ma of the advective-conductive model run.

S5.2. Transient thermal modelling of the upper plate

The second modelling stage aimed to assess the effect of transient conduction and advection in the thermal field of the overriding plate. We used a subarea of the structural and density model of Rodriguez Piceda et al. (2020) with the same refinement and resolution of the model described in the main text (section 2.3) to solve for the conductive transient thermal field with GOLEM (Cacace \& Jacquey, 2017; Jacquey \& Cacace, 2017). The formulation that describes the temperature calculation under transient conditions is:

$78 \quad \frac{\partial T}{\partial t}-\nabla\left(\frac{\lambda}{c_{p} \cdot \rho} \cdot \nabla T\right)=S(4)$

79 where $\mathrm{S}$ is the radiogenic heat production. The thermal properties $\mathrm{S}$ and $\lambda$ were applied for each

80 model unit as described in text S2. Densities were taken from the model of Rodriguez Piceda 81 et al. (2020). A heat capacity of $1200 \mathrm{~m}^{2} \mathrm{~s}^{-1}$ (Petitjean et al., 2006) was assigned for all the model units. Thermal properties are summarized in Table S2.

Dirichlet thermal boundary conditions were assigned along the top and the base of the model. The surface temperature of ERA-5 data set described in text S2 was set as fixed upper boundary condition. As time-dependent lower boundary condition, we used the thermal progression along this interface previously computed and explained in Text S5.1. We initialized

87 the simulation with the 3D thermal field of the model presented in the main text and run the model for $7 \mathrm{Ma}$. The initial model set up is schematized in Figure S10. 
89 Table S2. Thermal properties assigned to the units of the 3D structural model (Rodriguez Piceda et al.,

90 2020) to calculate the transient thermal field in the overriding plate.

\begin{tabular}{|l|l|l|l|l|}
\hline Layers & $\lambda\left[\mathbf{W m}^{-1} \mathbf{K}^{-1}\right]$ & $\mathbf{C p}\left[\mathbf{m}^{2} \mathbf{s}^{-1}\right]$ & $\rho\left[\mathbf{k g ~ m}^{-3}\right]$ & $\mathbf{S}\left[\boldsymbol{\mu} \mathbf{W m}^{-3}\right]$ \\
\hline Continental/oceanic sediments & $2.00^{1}$ & $1200^{2}$ & $2300 / 2400$ & $1.00^{3}$ \\
\hline Upper continental crystalline crust & $3.40^{1}$ & $1200^{2}$ & 2800 & $2.00^{3}$ \\
\hline Lower continental crystalline crust & $2.50^{1}$ & $1200^{2}$ & 3100 & $0.40^{4}$ \\
\hline Continental lithospheric mantle & $2.24^{5}$ & $1200^{2}$ & 3320 & $0.01^{3}$ \\
\hline
\end{tabular}

91 Note. $\lambda=$ bulk thermal conductivity; $\mathrm{Cp}=$ heat capacity; $\rho=$ bulk density; $\mathrm{S}=$ radiogenic heat

92 production. ${ }^{1}$ Čermák \& Rybach (1982); ${ }^{2}$ Petitjean et al. (2006); ${ }^{3}$ Vilà et al. (2010); ${ }^{4}$ Hasterok \&

93 Chapman (2011); ${ }^{5} \mathrm{Xu}$ et al. (2004)

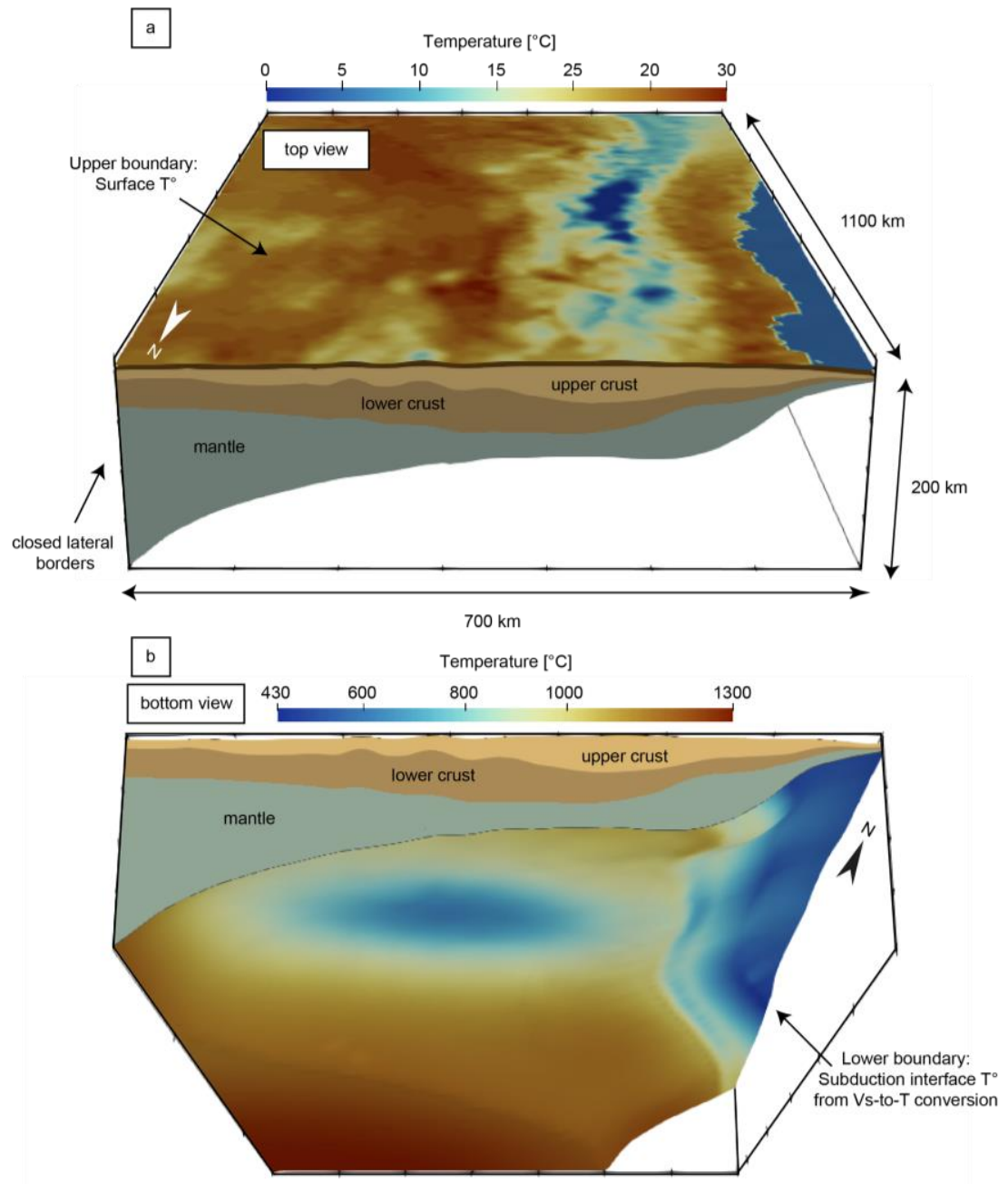

95 Figure S10. initial set up of the 3D transient model showing the thermal boundary conditions at the (a)

96 top and (b) bottom of the model. During the simulation, the upper boundary condition was fixed, while

97 the thermal progression along the subduction interface previously computed and explained in Text S5.1

98 was set as the lower transient boundary. 

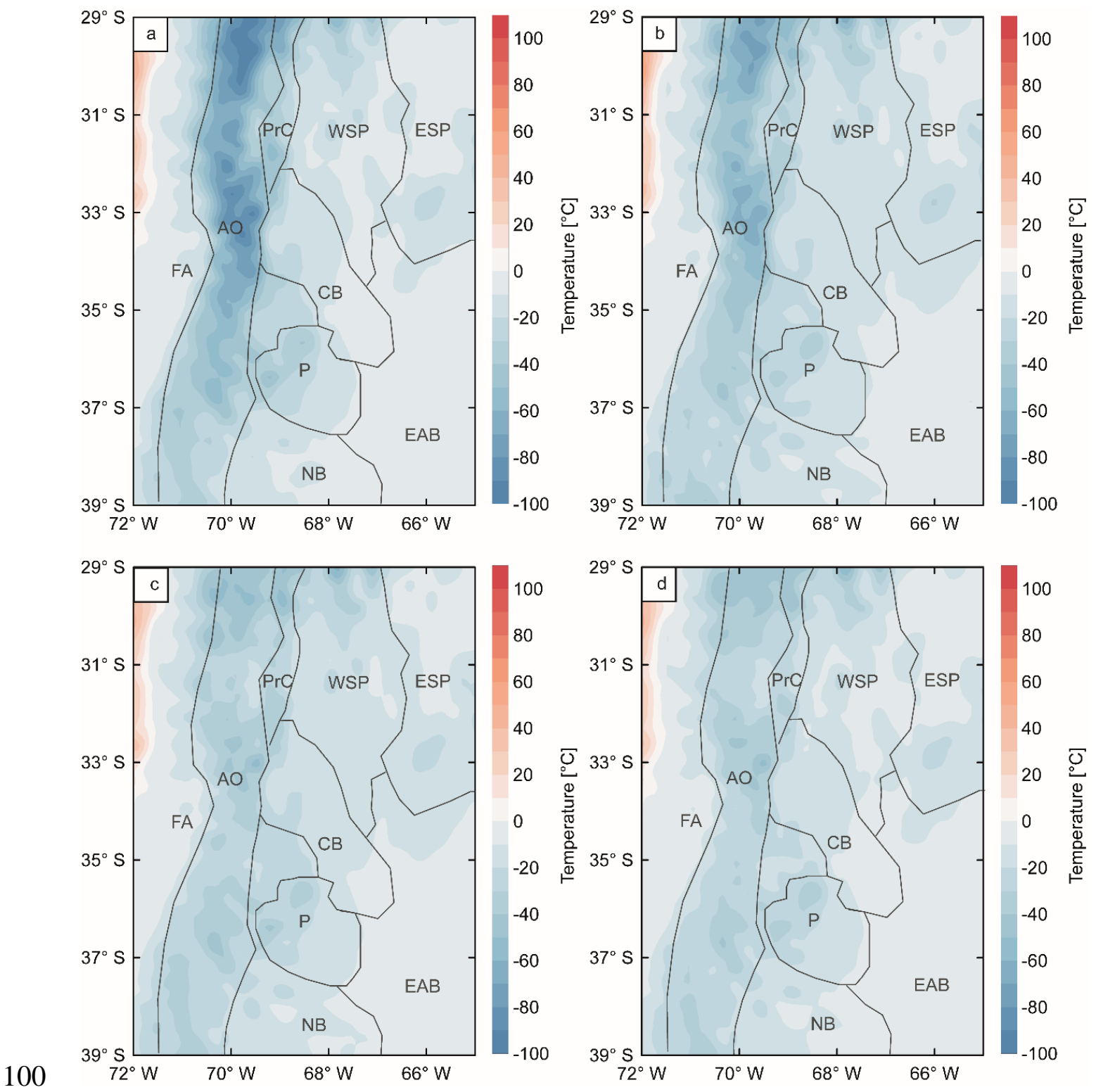

101 Figure S11. Difference maps between temperature slices using a lower boundary condition from the $\mathrm{v}_{\mathrm{s}^{-}}$ 102 to-T conversion with spinel and garnet lherzolite at depths of a) $10 \mathrm{~km}$, b) $20 \mathrm{~km}$, c) $30 \mathrm{~km}$ and d) 40 $103 \mathrm{~km}$. Key tectonic features are overlain (see Fig. 1 of main text for abbreviations). 

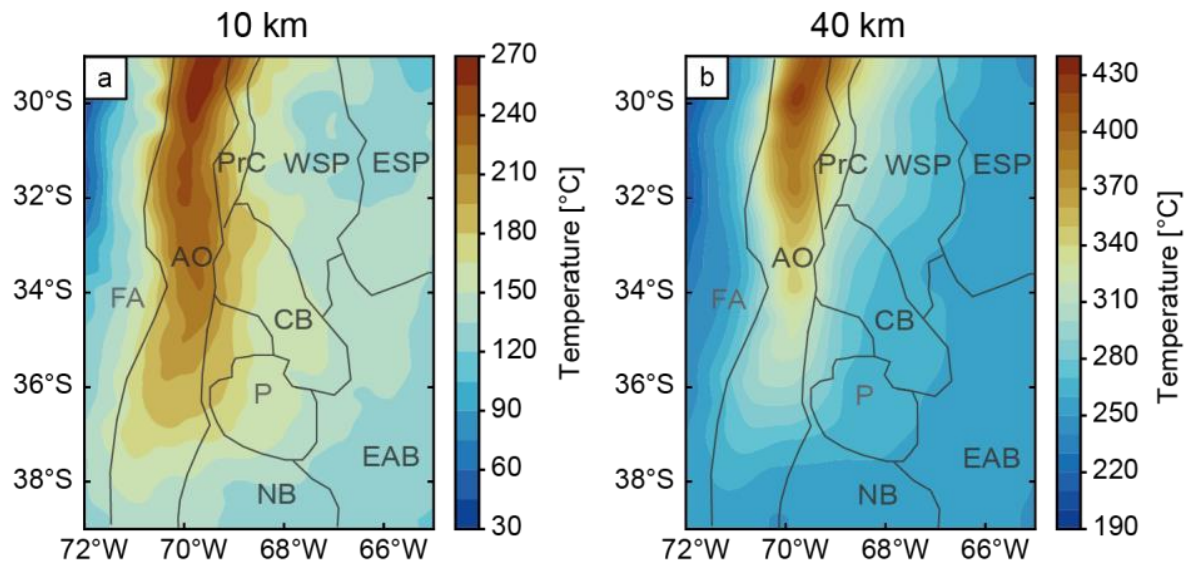

106 Figure S12. Temperature maps at depths of (a) $10 \mathrm{~km}$ and (b) $40 \mathrm{~km}$ of the model with a lower 107 boundary condition derived from a linear gradient of $5^{\circ} \mathrm{C} \mathrm{km}-1$ (Syracuse et al., 2010)

108
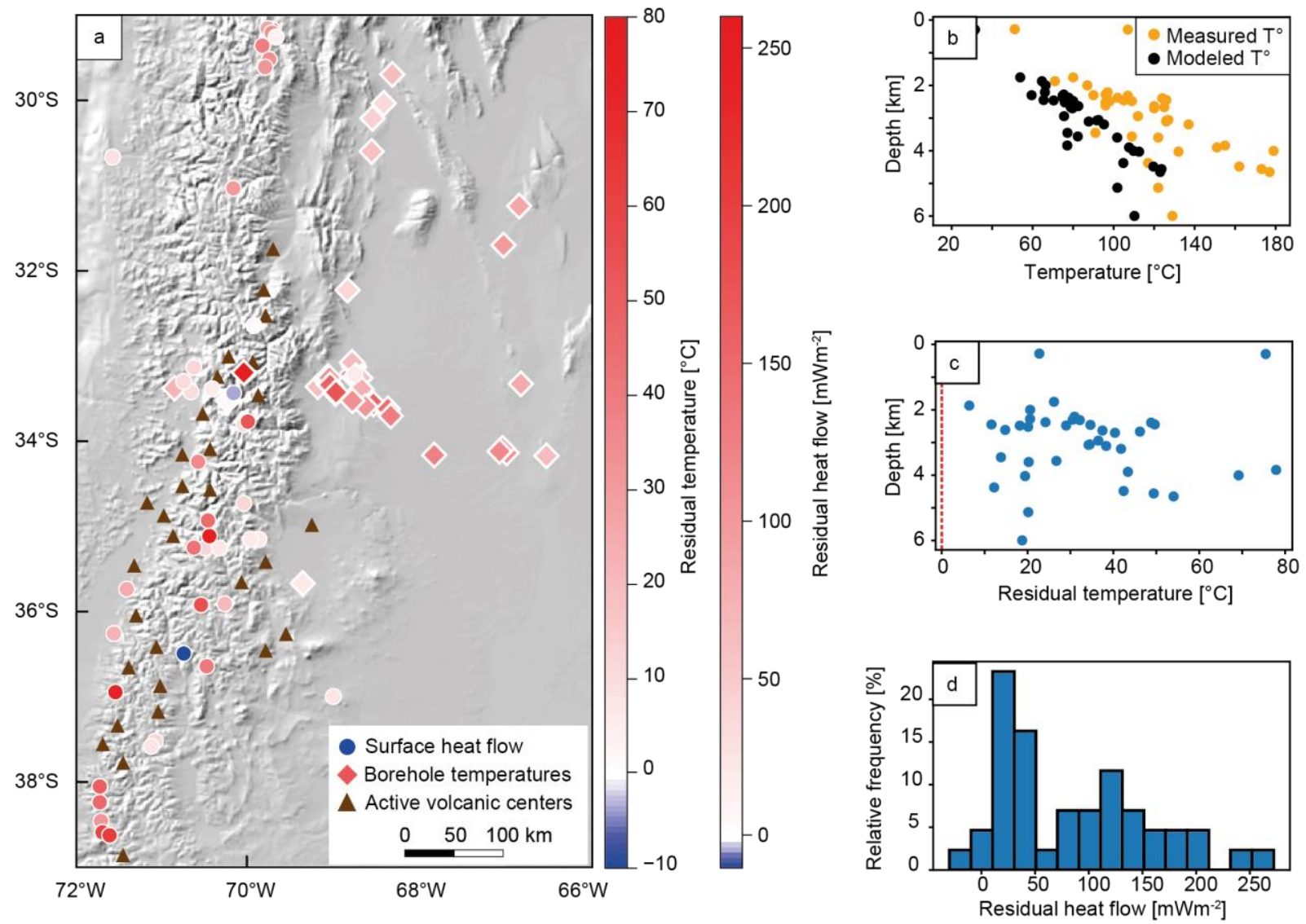

110 Figure S13. Comparison between thermal measurements (Collo et al. 2018, Lucazeau, 2019; Hamza

111 \& Muñoz, 1996; Uyeda \& Watanabe, 1982) and results from the model with a lower boundary

112 condition derived from a linear gradient of $5^{\circ} \mathrm{C} \mathrm{km}^{-1}$ (Syracuse et al. 2010). (a) residual temperature

113 and residual heat flow, defined as the difference between measured and modeled values, at the location

114 of the measurements. Triangles show the location of active volcanic centers; (b) comparison between

115 measured (orange) and modeled (black) temperatures $\mathrm{v}_{\mathrm{s}}$. depth; (c) residual temperature $\mathrm{v}_{\mathrm{s}}$. depth; and

116 (d) histogram of residual heat flow 